\title{
Trogossitidae, Lophocateridae, Peltidae and Thymalidae (Coleoptera: Cleroidea) of Poland: distribution, biology and conservation
}

\author{
MAREK MiŁKOWSKI ${ }^{1}$, JAN TATUR-DYTKOWSKI ${ }^{2}$, JERZY M. GUTOWSKI ${ }^{3}$, \\ RAFAŁ RUTA ${ }^{4 *}$, JANUSZ GRZYWOCZ ${ }^{5}$, SZYMON KONWERSKI ${ }^{6}$, \\ ROMAN KRÓLIK ${ }^{7}$, DANIEL KUBISZ ${ }^{8}$, ANDRZEJ LASOŃ ${ }^{9}$, ANDRZEJ MELKE ${ }^{10}$, \\ TOMASZ OLBRYCHT ${ }^{11}$, HENRYK SZOŁTYS ${ }^{12}$, MAREK WANAT ${ }^{13}$ \\ ${ }^{1}$ Królowej Jadwigi 19 m. 21, 26-600 Radom, Poland \\ ${ }^{2}$ Wąwozowa 4/17, 02-796 Warszawa, Poland \\ ${ }^{3}$ Forest Research Institute, Department of Natural Forests, 17-230 Białowieża, Poland; \\ ORCID: 0000-0002-5085-2557 \\ ${ }^{4}$ Department of Biodiversity and Evolutionary Taxonomy, University of Wrocław, \\ Przybyszewskiego 65, 51-148 Wrocław, Poland; ORCID: 0000-0002-2039-7979 \\ ${ }^{5}$ Szpitalna 19, 41-711 Ruda Śląska, Poland \\ ${ }^{6}$ Natural History Collections, Faculty of Biology, Adam Mickiewicz University, \\ Umultowska 89, 61-614 Poznań, Poland; ORCID: 0000-0002-6438-8759 \\ ${ }^{7}$ Mickiewicza 8, 46-200 Kluczbork, Poland \\ ${ }^{8}$ Institute of Systematics and Evolution of Animals PAS, Św. Sebastiana 9, 31-049 \\ Kraków, Poland \\ ${ }^{9}$ Wiejska 4B/85, 15-352 Białystok, Poland \\ ${ }^{10}$ Św. Stanisława 11/5, 62-800 Kalisz, Poland; ORCID: 0000-0002-2039-7979 \\ ${ }^{11}$ University of Rzeszów, Faculty of Biology and Agriculture, Department of Agroecolgy, \\ M. Ćwiklińskiej 1a, 35-601 Rzeszów, Poland \\ ${ }^{12}$ Park 9, 42-690 Brynek, Poland \\ ${ }^{13}$ Museum of Natural History, University of Wrocław, Sienkiewicza 21, 50-335 Wrocław, \\ Poland; ORCID: 0000-0001-8560-7095
}

* Corresponding author: rafal.ruta@uwr.edu.pl 


\begin{abstract}
Distributional data for 10 species of Peltidae, Lophocateridae, Trogossitidae and Thymalidae recorded from Poland are summarised, and numerous unpublished records are reported. Data on feeding and habitat preferences are analysed. Calitys scabra and Temnoscheila caerulea are probably extinct in Poland. Grynocharis oblonga, Nemozoma elongatum and Tenebroides mauritanicus are relatively common in Poland. Nemozoma caucasicum is currently spreading within Europe and several new records in Poland are reported. Peltis ferruginea, $P$. grossa, and Thymalus limbatus are restricted to natural forests in Poland, where they are sometimes abundant. We suggest adding Peltis ferruginea and Thymalus limbatus to the Polish Red List of Animals. The opinion that Grynocharis oblonga and Tenebroides mauritanicus are relicts of natural forests does not seem justified.
\end{abstract}

KEY WORDS: Bark-gnawing beetles, saproxylic species, faunistics, new records, distribution maps.

\title{
INTRODUCTION
}

Trogossitidae and related families of beetles belong to the most unstable and problematic family-level taxa within the superfamily Cleroidea. A recent study based on molecular data (GIMMEL et al. 2019) showed that Trogossitidae (sensu: BOUCHARD et al. 2011) should be divided into several families, including Trogossitidae, Lophocateridae, Peltidae and Thymalidae. Most of the species recorded in Poland are easily identifiable, but despite this, our knowledge of their distribution, biology and habitat preferences is still limited. Historical data on the species recorded in Poland are summarised in BOROWIEC (1983) and BURAKOWSKI et al. (1986). A key to the identification of species known from central Europe was published by KOLIBÁČ (1993) and again by KoLIBÁČ et al. (2005).

The present paper deals with 10 species and 8 genera that have hitherto been recorded in Poland. Only some species are commonly recorded. Several of the rare species occur in natural forests, where they are associated with large-sized deadwood and wood-inhabiting fungi. Two species - Calitys scabra (THUNBERG, 1784) and Temnoscheila caerulea (OLIVIER, 1790) - have not been observed in Poland for over 100 years. Lophocateres pusillus (KLUG, 1833) is known from a single, accidental introduction to Poland.

In this paper, we have gathered unpublished data on ca. 3500 specimens collected in over 200 UTM squares $(10 \times 10 \mathrm{~km})$ from institutional and private collections (Fig. 1). We have summarised data on the occurrence and habitat preferences in Poland of each species. 


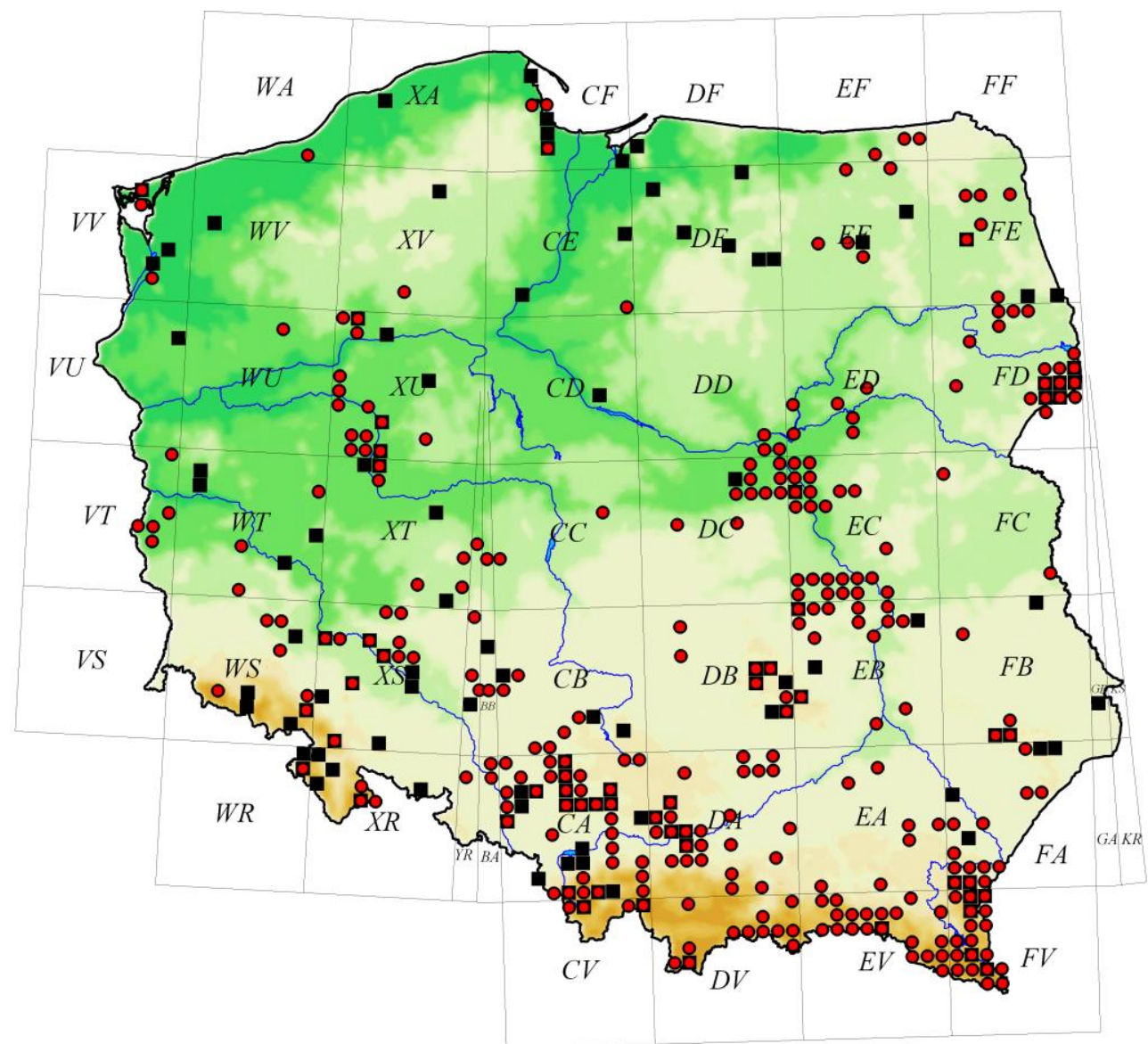

Fig. 1. Published records of Trogossitidae, Lophocateridae, Peltidae, and Thymalidae in Poland (black squares) and findings reported in the present paper (red circles).

\section{MATERIALS AND METHODS}

In the review of species, the division of Poland into regions is adopted after BURAKOWSKI et al. (1973). Records within a region are ordered alphabetically, and a 10 $\mathrm{x} 10 \mathrm{~km}$ UTM square is given for each record. Distribution maps were created with Gnomon 3.2 software. When only an approximate locality is known, e.g. the localities denoted as "Przemyśl vic." in the collection of T. TRELLA, the UTM square is marked with an asterisk $(*)$. 
Published records presented on the maps (Fig. 1-2, 4, 7-11, 13) are based on the following papers: RENDSCHMidT (1841), KelCH (1846), ZEBE (1852), RogER (1856), ROTTENBERG (1864, 1868), JABŁOŃSKI (1869), REITTER (1870), WACHTL (1870), LETZNER (1871), VierTl (1872), KotUla (1873), NowiCKI (1873), LENTZ (1879), FeIN \& HAASE (1881), STOBIECKI (1883), ŁOMNICKI (1886), LETZNER (1888), SCHUMANN (1904), ALBIEN (1905), Lgocki (1908), Gerhardt (1910), RieHn (1912), TENENBAum (1913), WANKA (1915), DORN (1919), SZULCZEWSKI (1922), NOWOTNY \& POLENTZ (1933), RUSZKOWSKI (1933), SCHMIDT (1935), KUNTZE (1936), SCHMIDT (1938), STEFEK (1939), KLEINE (1940), POlENTZ (1942), SKURATOWICZ \& URBAŃSKI (1953), JANICKI et al. (1959), HORION (1960), PAWŁowSKI (1967, 1968), SENICZAK (1968), CAPECKI (1969), GIDASZEWSKI (1974), BaŁAZY \& Michalski (1977), Bercio \& FolWACZNY (1979), PRĄDZYŃSKa (1988), KuBISZ \& SZWAŁKo (1991), PAWŁOWSKI et al. (1994), GRZYWocZ \& SZOŁTYS (1996), MAZUR et al. (1996), BURAKOWSKI (1997), KONWERSKI (1997), SZAFRANIEC (1997), SZAFRANIEC \& SZOŁTYS (1997), SZAFRANIEC et al. (1999), BOROWSKI (2001), BYK (2001), MokrzYCKi (2001, 2002), RUtKIEWICZ (2001), RUtA \& MelKe (2002), MeLKE \& GRZYWOCZ (2003), BYK \& BYK (2004), BYK et al. (2006), GUTOWSKI et al. (2006), HILSZCZAŃSKI (2006), TYKARSKI (2006), BOROWIEC (2007), BYK (2007), RUTA (2007), MiKOWSKI \& WOJAS (2008), MOKRZYCKI et al. (2008), BUCHHOLZ \& BIDAS (2012), PLEWA et al. (2014), OLBRYCHT et al. (2015), PAPIS \& MOKRZYCKI (2015), HolLy (2016), RUTA et al. (2016), MÆKOWSKI (2017), BUCHHOLZ \& MELKE (2018), TATUR-DYTKOWSKI (2018).

Collectors: AB - Antoni BARTOSZYŃSKI; ABO - Adam BOHDAN; AEBG - Andrzej GruszKA, Ewa GrusZKA and Barbara GrusZKA; AJ - Andrzej JANKowiCZ; AK - Adam KISIEL; AL - Andrzej Lasoń; ALU - Albert LÜllwitz; AM - Andrzej MelKe; AMA - A. MACIEJEWSKI; AR - Adolf RIEDEL; AS - Andrzej SZEPTYCKI; BB - Bolesław BURAKOwSKI; BG - Barbara GRUSZKA; BK - Bolesław KoTULA; BP - Bohdan PISARSKI; DI - Dariusz IwAN; DK - Daniel KUBISZ; EB - Edward BARANIAK; EG - Ewa GrUSZKA; EK - Eugeniusz KIERYCH; EM - Edward MAZUR; EW - Eustachy WRÓBLEWSKI; FF Franciszek FeJFER; FK - Franz KIRSCH; GP - Georg POLENTZ; HN - Hans NOwOTNY; HS - Henryk SzOŁTYS; JG - Janusz GRZYwOCZ; JKM - Jan Kajetan MŁYNARSKI; JŁ - Jerzy ŁUGOWOJ; JM - Jacek MAROŃ; JMA - Józef MAKÓLSKI; JMG - Jerzy M. GUTOWSKI; JP Jerzy PAWŁowSKI; JPA - J. PAJĄK; JPO - J. PODOSKI; JR - Jerzy RAZOWSKI; JS - Jan SIEKIERSKI; JTD - Jan TATUR-DYTKOWSKI; KB - K. BIELEWICZ; KK - Kurt KunTZE; KL - Krzysztof LUBECKI; KLE - Karl LETZNER; KP - K. PTAK; KS - Karol STEFEK; KSU Krzysztof SUĆKO; KT - K. TERLECKI; KZ - Katarzyna ŻUK; LB - Lech BOROwIEC; LBU Lech BUCHHOLZ; MB - Marek BARTOSIK; MBM - Maciej MROCZKOwsKI; MKS - Monika KUCHARSKA-ŚWIERSZCZ; MB - Mariusz BoĆKOWSKI; MM - Marek MiŁKOwSKI; MR Michał RYBIŃSKI; MW - Marek WANAT; PCH - Piotr ChAChUŁA; PF - P. FRANK; PH - P. 
HeYMes; PJ - Paweł JaŁoszYŃSKi; PK - Piotr KośCióŁeK, PT - Przemysław TROJAN; RB Ryszard BIELAWSKI; RBO - R. BOREK; RD - Roland DoBOsZ; RK - Roman KRÓLIK; RP Radosław PLEWA; RR - Rafał RUTA; RS - Richard SCHOLZ; SA - Stanisław ADAMCZEWSKI; SAS - Stefan A. STOBIECKI; SK - Szymon KONWERSKI; SKA - Stanisław KADYI; SN Szymon NowAKOwSKI; SP - Stanisław POPEK; SSZ - Stanisław SzAFRANIEC; ST - Szymon TENEnBAum; STO - Sergiusz Toll; TB - Tadeusz BzIUK; TH - Tomasz HufleJT; TK Tomasz KoŚCIELNY; TM - Tomasz MAJEwSKI; TN - Tomasz NABIAŁKOWSKI; TO Tomasz OlBRYChT; TT - Tadeusz TRELlA; WB - W. BEDNAREK; WD - Władysław DOLIŃSKI; WE - Witold EICHLER; WK - Wilhelm KOLBE; WKU - Wojciech KUBASIK; WM - Wojciech MĄCZYŃSKI; ZS - Zygmunt ŚLIWIŃSKI; ZSC - Zbigniew SCHNAIDER; ZSP Zygmunt SIERPIŃSKI; ZW - Z. WIERZBICKI.

Depositories (if different from the finder's collection): $[A L]$ - coll. A. LASON', Białystok; [AM] - coll. A. MeLKe, Kalisz; [HS] - coll. H. SzOŁTYS, Brynek; [ISEA] Institute of Systematics and Evolution of Animals, Polish Academy of Sciences, Kraków; [JG] - coll. J. GRZYwOCZ, Ruda Śląska; [JMG] - coll. J.M. GUTOwsKI, Białowieża; [KR] coll. K. RUDZIŃSKI, Złocieniec; [MIZ] - Museum and Institute of Zoology, Polish Academy of Sciences, Warsaw; [MM] - coll. M. MıŁKOwSKI, Radom; [MNHW] Museum of Natural History, Wrocław University, Wrocław; [PJ] - coll. P. JAŁOSZYŃSKI, Poznań; [PNPM] - collection of the Pieniny National Park museum; [RK] - coll. R. KRÓLIK, Kluczbork; [RP] - coll. R. PLEWA, Sękocin Stary, [RR] - coll. R. RUTA, Wrocław; [SDEI] - Senckenberg Deutsches Entomologische Institut; [SK] - coll. Sz. KONWERSKI, Poznań; [TO] - T. OlBRYCHT, Rzeszów; [USMB] - Upper Silesian Museum, Bytom.

The original spelling of localities is given in square brackets.

Abbreviations used in the text: ad - near, coll. - collection; comp. - forest compartment ("oddział leśny"); cult. - reared; ex. (exx.) - specimen (specimens); det. identified (by); for. distr. - forest district ("nadleśnictwo"); for. div. - forest division ("leśnictwo"); Is. - island; leg. - collected (by); LP - Landscape Park; Mt. (Mts.) mountain (mountains); NP - National Park; obs. - observation; res. - nature reserve; SAC Natura 2000, Special Area of Conservation; vic. - vicinity.

\section{SPECIES OVERVIEW}

\section{Family: Trogossitidae \\ Calitys scabra (THUNBERG, 1784)}

Material examined. Eastern Sudeten Mts.: Kłodzko (Glatz) (XR18), collecting date unknown - 1 ex., leg. KLE [SDEI]. Western Beskid Mts.: Roztoka Wielka (DV78), Radziejowa Mt., 16 VII 1898 - 1 ex., leg. SAS (published as "vicinity of Rytro" in RossA 
2004). Tatra Mts.: Kuźnice (DV25), 2 VII, year unknown (end of $19^{\text {th }}$ century) -2 exx., leg. MR [ISEA]; "Tatry", without precise locality, mid- $19^{\text {th }}$ century -2 exx., leg. EW [ISEA].

Distribution. A widely distributed species, extending from western Europe and north Africa to the Russian Far East and North America. A boreal-montane species in Europe, nowadays extinct in many localities. In Poland known from $19^{\text {th }}$ century findings but never found since (Fig. 2, 3). The species has not been recorded from the Tatra Mts. before. Regarding its occurrence in the Czech eastern Sudeten Mts. (MERTLIK 2011), further searches are necessary, as a rediscovery of the species is still possible.

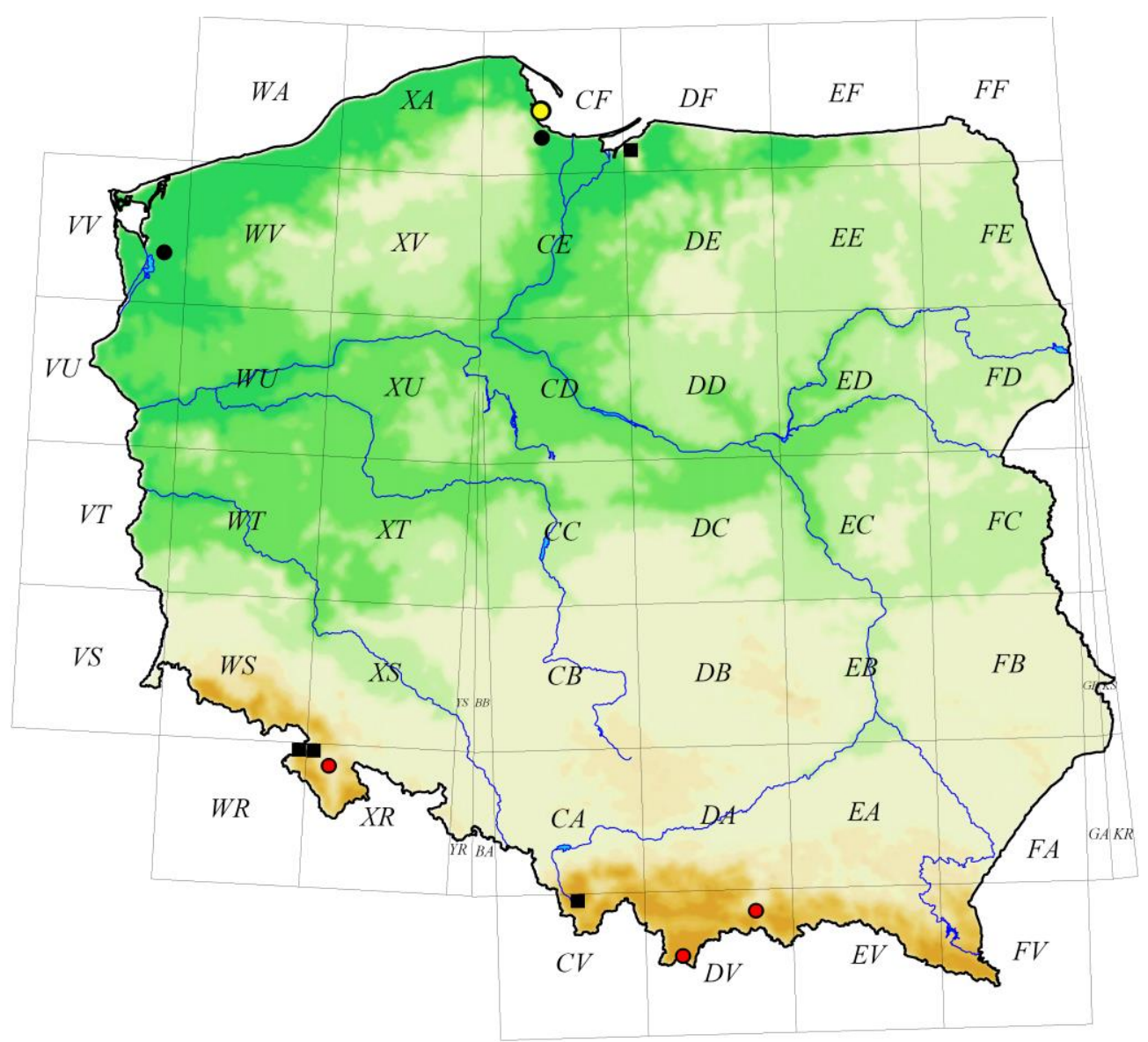

Fig. 2. Calitys scabra (published records - black squares, old records reported in the present paper - red circles), Temnoscheila caerulea (published records - black circles) and Lophocateres pusillus (yellow circle) - distribution in Poland. 


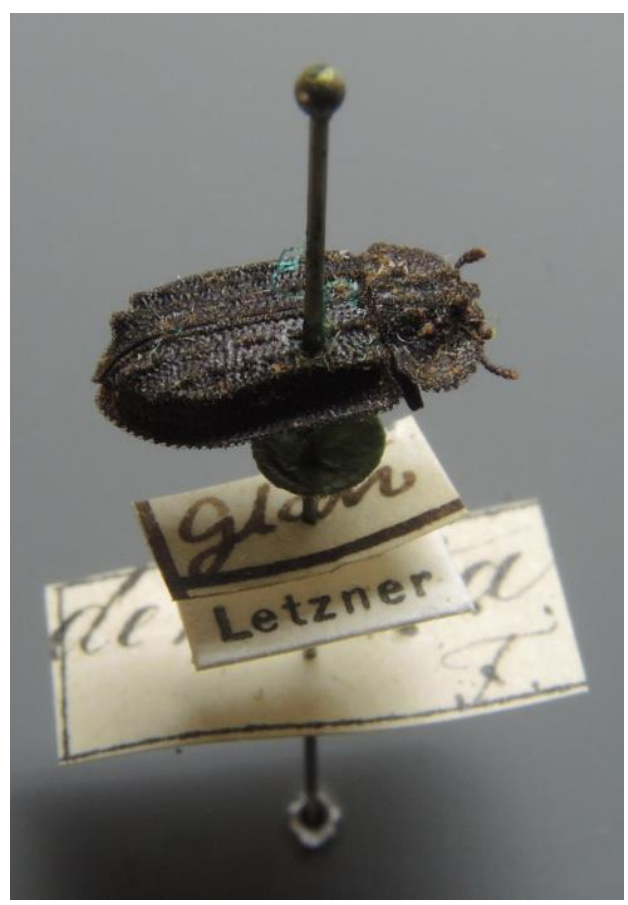

Fig. 3. Calitys scabra - a historical specimen collected near Kłodzko (= Glatz) by K. LETZNER, deposited in the Senckenberg Deutsches Entomologische Institut, Müncheberg; phot. R. RUTA.

Biology. Develops in old, rotting coniferous trees, like spruce, pine, larch and fir; larvae feed on fungi; adults are usually collected under bark and in rotting wood (KoLIBÁČ et al. 2005).

\section{Nemozoma caucasicum MÉNÉTRIÉS, 1832}

Material examined. Wielkopolska-Kujawy Lowland: Plewiska ad Poznań (XU20), 23 IX-30 X 2017 - 30 exx., 15 IV-10 V 2018 - 12 exx., on a stack of firewood (mostly ash branches, $15-30 \mathrm{~cm}$ in diameter), leg. SK. Małopolska Upland: SAC "Dolina Zwoleńki”, "Borowiec" res. (EB58), 1 V-25 V 2018 - 1 ex., IBL-2 window trap with a set of pheromones, edge of pine forest, leg. MM. Upper Silesia: Piekary Śląskie, Kozłowa Góra (CA58), 30 IX 2017 - 10 exx., in galleries of Hylesinus varius (FABR.) on a small piece of a Fraxinus excelsior L. branch lying on the ground, with numerous pupae, leg. HS, 28 X 2017 - 5 exx., under the bark of a dead branch of Fraxinus excelsior, in galleries of Hylesinus sp., leg. RK [JG]; "Łężczok" res. (CA05), 20 VI- 9 VII 2018 - 1 ex., leg. JM [HS] (IBL2 trap). Sandomierz Lowland: Rzeszów, Śródmieście, Jagiellońska Street (EA74), 26 III 2011 - 1 ex., basement in a tenement house, on firewood, leg. PK [TO], det. AM. 
Distribution. Species described from the Caucasus; recorded in Crimea, Germany, Austria, Poland, Slovakia and France (KoliBÁČ 2007, PANKOW 2010, BRUSTEL \& RogÉ 2011). Records from some European countries during the past dozen or so years may be interpreted as an ongoing expansion. However, the oldest French specimen was collected in 1927 (BRUSTEL \& ROGÉ 2011). Recently recorded in the Mazovian Lowland (HILSZCZAŃSKi 2006) as new for the Polish fauna. Also recorded in the Małopolska Upland and the Kraków-Częstochowa Upland (MıŁowsKI \& WOJAS 2008), Lublin Upland (PLEWA et al. 2014) and other localities in the Mazovian Lowland (TATUR-DYTKOWSKI 2018). The species is new for the Wielkopolska-Kujawy Lowland, Upper Silesia and the Sandomierz Lowland (Fig. 4).

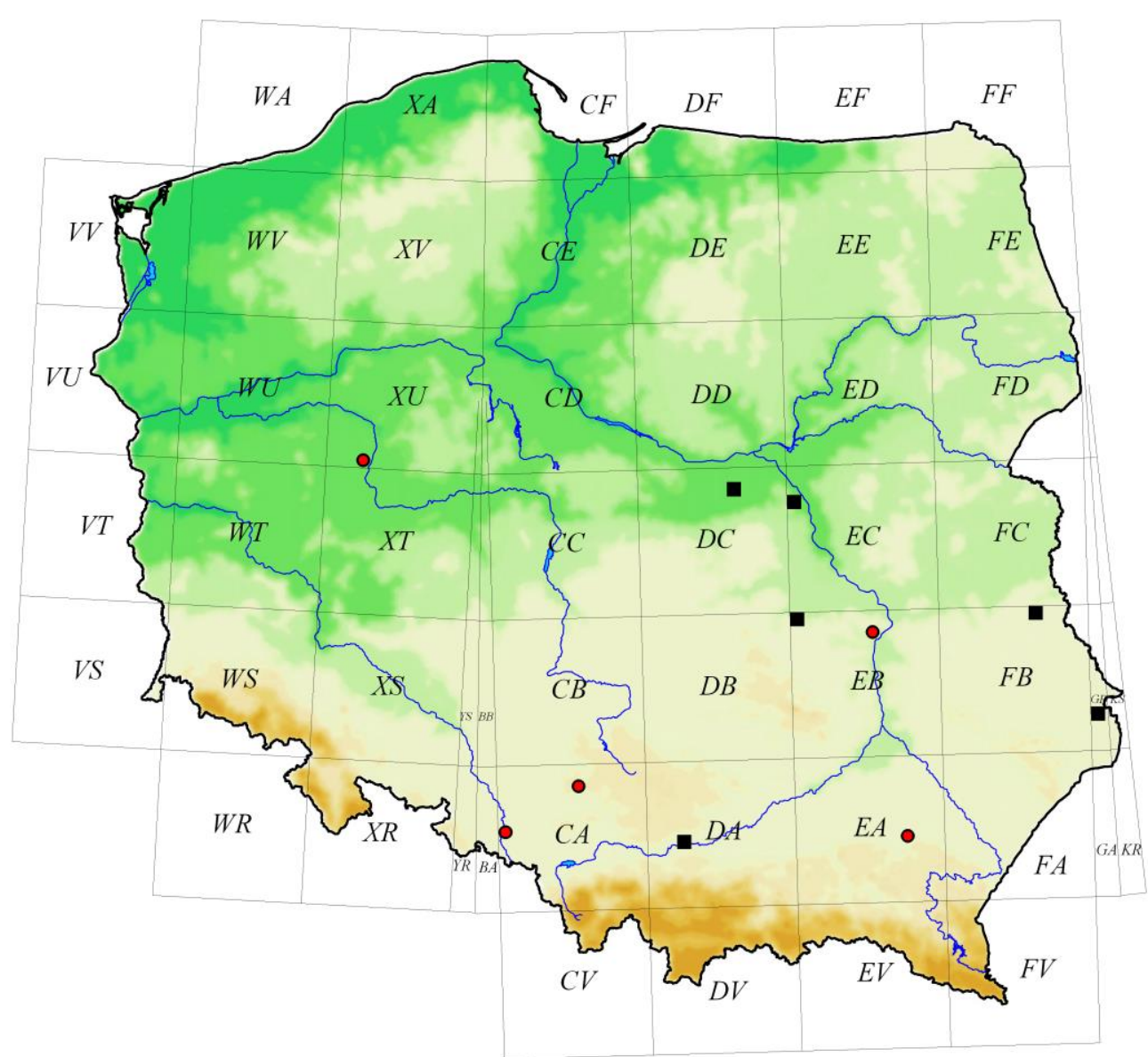

Fig. 4. Nemozoma caucasicum (published records - black squares, records reported in the present paper - red circles) - distribution in Poland. 
Biology. According to observations from southern Russia, larvae develop in galleries of Hylesinus fraxini (PANZER, 1779) on ash, galleries of Scolytus mali (BECHSTEIN, 1805) on pear and in galleries of Pteleobius vittatus (FABRICIUS, 1792) on elm. The species has recently been recorded in central Poland on ash infested by Hylesinus crenatus (FABRICIUS, 1787) (Fig. 5). The beetles were found penetrating $H$. crenatus mother galleries in search of bark beetles (Fig. 6). A N. caucasicum imago was observed consuming a female of $H$. crenatus captured in its own gallery (TATUR-DYTKOWSKI 2018). Adult beetles emerge from the end of April or the beginning of May (KoLIBÁČ et al. 2005). According to recent observations, adults are active both in the bark and on its surface, where they actively search for bark beetles. Imagines prefer thick bark with cracks. They are active both in daylight and after dusk until midnight (TATUR-DYTKOWSKI 2018).

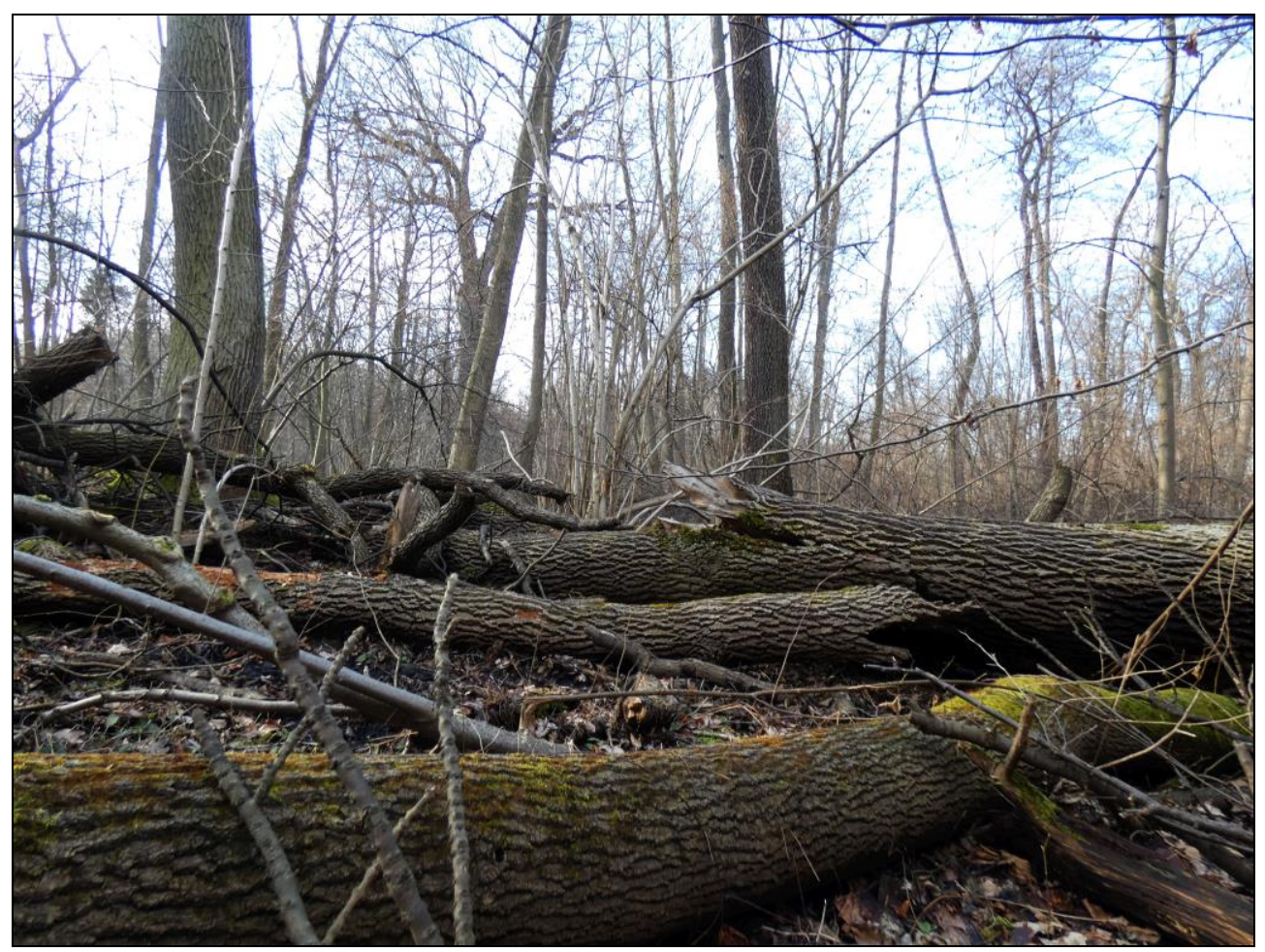

Fig. 5. Habitat of Nemozoma caucasicum - ash-alder carr (Fraxino-Alnetum), "Las Natoliński" nature reserve in Warsaw; phot. J. TATUR-DYTKOWSKI. 


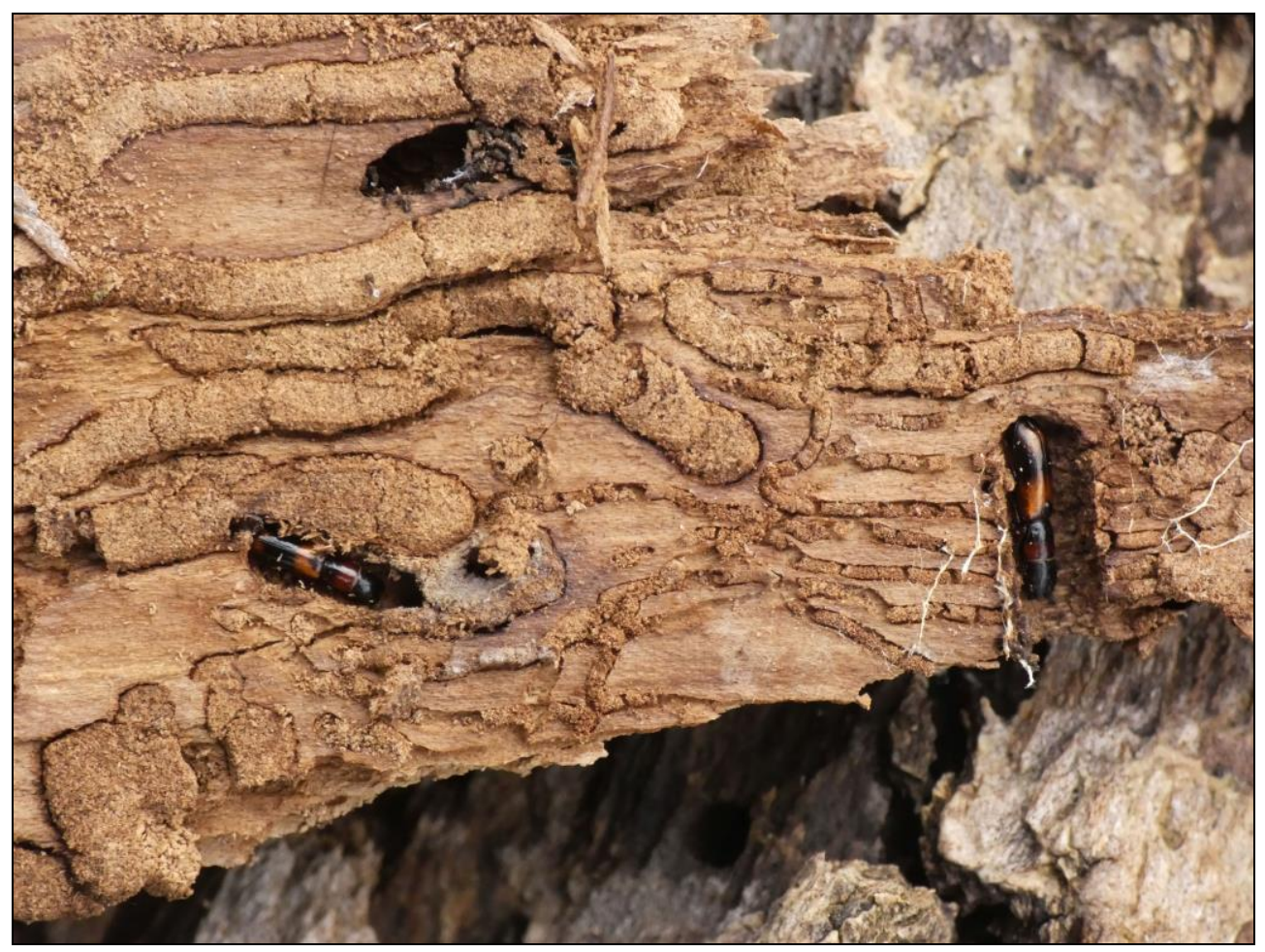

Fig. 6. Adults of Nemozoma caucasicum in larval galleries of Hylesinus crenatus (FABRICIUS, 1787) under the bark of Fraxinus excelsior L., "Las Natoliński" nature reserve in Warsaw; phot. J. TATUR-DYTKOWSKI.

\section{Nemozoma elongatum (LINNAEUS, 1761)}

Material examined. Pomeranian Lake District: Kujan vic. (XV41), near Karolewo forester's lodge, 14 VIII 1999 - 2 exx., under the bark of a Picea abies (L.) H. KARST. branch, leg. RR. Masurian Lake District: Pisz Forest ("Puszcza Piska"), Snopki vic. ad Pisz, comp. 241 (EE44), pine forest, 28 V-17 VI 2013 - 1 ex., in an IBL-2bis barrier trap, leg. JMG; Pisz Forest, Snopki vic. ad Pisz, comp. 248 (EE44), pine forest, 9 VI-1 VII 2009 -2 exx., in an IBL-2bis barrier trap, leg. JMG; Romincka Forest ("Puszcza Romincka"), Jurkiszki (EF81), 3 VII 2014 - 1 ex., leg. RP; Sosnowo vic., Sztabin (FE35), 24 V 2003 2 exx., on a stump of Picea abies, leg. MW. Wielkopolska-Kujawy Lowland: Puszczykowo vic. ad Poznań (WT97), pine forest, 6 V 1995 - 2 exx., under the bark of Pinus sylvestris L., in galleries of Scolytinae, leg. PJ. Mazovian Lowland: Borszyce ad Mszczonów (DC65), 7 IV 2005 - 2 exx., in a rotten limb of Tilia sp., leg. JTD; Cegłów ad 
Błonie (DC67), 16 IV 2015 - 2 larvae, from branches of Tilia cordata MILL. lying on the ground, reared 4 VI 2015, leg. RP; Kozienice Forest ("Puszcza Kozienicka"), Augustów (EC30), 24 II 2001 - 1 ex., from a branch of Picea abies collected on 17 II 2001, leg. MM; Kozienice Forest, Dąbrowa Kozłowska (EC20), 6 V 2000 - 1 ex., from a branch of Quercus sp. collected on the ground, leg. MM; Kozienice Forest, Januszno (EC30), 26 XII $2002-1$ ex., from a branch of Tilia cordata, leg. MM, 17 I $2003-2$ exx., from a branch of T. cordata, leg. MM; Kozienice Forest, Przejazd vic. (EC30), 3 IV $2004-1$ ex., under the bark of Abies alba MiLl., leg. MM; Kozienice Forest, Stara Brzóza (EC21), 2 IV 2006 3 exx., Tilia cordata, reared 1-15 XII 2006, leg. RP; Kozienice Forest, "Załamanek" res. (EC20), 8 III 2007 - 1 ex., from a branch of Abies alba collected on 18 II 2007, leg. et cult. MM; Żabieniec ad Piaseczno (near a forest nursery) (EC06), 2 X 2013 - 4 exx., Tilia cordata, reared until 1 IV 2014, leg. RP. Podlasie: Olmonty ad Białystok (FD48), 21 IV $2000-1$ ex., in flight in mixed broadleaved forest, leg. AL. Bialowieża Primeval Forest: Białowieża NP, comp. 253D (FD84), Narewka river valley, 18-24 VI 1997 - 1 ex., 16-22 VI 1999 - 1 ex., in IBL-2bis barrier traps, leg. JMG; Białowieża NP, comp. 282B (FD85), Narewka river valley, 27 V-2 VI 1998 - 1 ex., 19-25 V 1999 - 1 ex., 3-9 V 2000 - 1 ex., in IBL-2bis barrier traps, leg. JMG; Białowieża NP, comp. 288C/318A (FD94), mixed broadleaved forest, 4 VII 1989 - 1 ex., in a turpentine baited IBL-2bis barrier trap, 2 VII 1993 - 1 ex., 1 VI 2006 - 1 ex., 24 V 2007 - 1 ex., in an unbaited barrier trap, 27 V 2006 1 ex., in a Moericke yellow pan trap installed at a height of $1 \mathrm{~m}$, leg. JMG; Białowieża NP, comp. 368E (FD94), Narewka river valley, 2-8 VI 1999 - 3 exx., 17-23 V 2000 - 1 ex., in IBL-2bis barrier traps, leg. JMG; Białowieża NP/for. distr. Białowieża, Droga Browska, comp. 374D/403B (FD94), 11-25 VII 1996 - 1 ex., 13-19 V 1997 - 1 ex., 27 V-2 VI 1998 - 1 ex., 10-16 VI 1998 - 2 exx., 8-14 VII 1998 - 1 ex., in unbaited IBL2-bis barrier traps, leg. JMG; Białowieża NP/for. distr. Białowieża, Droga Browska, comp. 375B/375D (FD94), 7-13 V 1997 - 1 ex., 14-19 V 1997 - 1 ex., 20-27 V 1997 - 2 exx., 2-8 VII 1997 - 1 ex., 30 V-6 VI 1999 - 1 ex., 17-23 V 2000 - 1 ex., in IBL-2bis barrier traps, leg. JMG; for. distr. Białowieża, ad Teremiski, Dębina settlement vic., comp. 338A (FD84), oakhornbeam forest, 22 V-9 VI 2014 - 1 ex., in a funnel trap installed in the tree crown, leg. JMG; for. distr. Białowieża, ad Teremiski, comp. 424C (FD84), Tilio-Carpinetum oakhornbeam forest, $25 \mathrm{~V} 2015-2$ exx., in an IBL-2bis barrier trap, leg. JMG; for. distr. Hajnówka, "Głęboki Ką̨" res., comp. 439A (FD74), 16 V 1989 - 4 dead exx., reared from a broken spruce Picea abies $20 \mathrm{~cm}$ in diameter, collected on 31 VII 1986, also inhabited by Ips typographus (L.), Polygraphus poligraphus (L.) and Acanthocinus griseus (FABR.), leg. et cult. JMG; Olchówka, comp. 42 (FD85), 20 II 2016 - 1 ex., reared from a branch of Picea abies, leg. JŁ [AL]; Witowo, railway station (FD63), 13 V 1993 - 1 ex., leg. MW. Lower Silesia: Słup (XS17) [Schlaupe Kr. N.] - 1 ex., leg. GP [MNHW]; Sobótka (XS24), 29 V 1949 - 1 ex., ex coll. AEBG [MNHW]; Świebodzice (WS93), 16 IX 1962 - 1 larva, 
leg. BB [MIZ]; Wrocław (XS46) [Breslau], ex coll. GP [MNHW]; Wrocław-Wilkszyn, Las Mokrzański (XS37), 25 VI 2006 - 1 ex., leg. MW. Trzebnica Hills: Trzebnica (XS49), 30 IV 1976 - 1 ex., leg. JŁ [USMB]. Upper Silesia: Blachówka (CA48), VI 2016 - 2 exx., ex cult from bark of Picea abies, leg. HS; Brynek (CA39), 10 IV 1993 - 1 ex., 26 II 1994 6 exx., 4 XII 1999 - 2 exx., 26 I 2002 - 1 ex., II 2002 - 1 ex., reared, VII 2002 - 2 exx., reared, leg. HS; Bytom (CA57), 4 IX 1931 - 2 exx., leg. FK [USMB]; Bytom, Dąbrowa Miejska [Beuthen O. S. Stadtwald] (CA48), 1 IX 1931 - 1 ex., leg. HN, ex coll. GP [MNHW], 10 IX 1931 - 1 ex., 20 IX 1931 - 1 ex., 24 IX 1931 - 2 exx., leg. HN [USMB]; Cieszowa (CB41) - 2 V 1984, leg. HS [JG]; Jasienie ad Kluczbork (CB04), 8 V 1995 1 ex., in flight, 23 X $2004-1$ ex., under the bark of a dead branch of Picea abies, leg. RK; $3 \mathrm{~km}$ SW of Jasienie ad Kluczbork (CB04), 4 XI 2013 - 1 ex., from a thin trunk of Picea abies, ex cult. 1-15 I 2014, leg. RK; Katowice-Ligota (CA56), I 2011 - 1 ex., ex cult, leg. TB [HS]; "Łężczok" res. (CA05), 18 VII 2016 - 1 ex., leg. JM [HS]; Mikołów-Mokre, Fiołkowa Góra (CA46), 12 V 2011 - 1 ex., leg. JG; for. distr. Kluczbork, for. div. Bąków, comp. 234 (CB04), 9 III 1991 - 1 ex., under the bark of $P$. abies, in galleries of Pityophthorus sp., leg. RK; for. distr. Kluczbork, for. div. Zameczek, comp. 137 (BB94), 9 V 1999 - 1 ex., under the bark of Abies alba, in galleries of Cryphalus piceae (RATZ.), leg. RK; for. distr. Kluczbork, for. div. Zofiówka (CB15), 17 V 1991 - 1 ex., in an Ips typographus pheromone-baited trap, leg. RK; Góra św. Anny LP (BA99), 1 V 2002 - 1 ex., leg. JG; Góra św. Anny LP, Czarnocin (CA09), 26 V 2005 - 43 exx., leg. JG; Ruda Śląska, Las Alina (CA47), 19-23 V 2006 - about 200 exx., in an Ips typographus pheromone-baited trap, leg. JG; Ruda Śląska-Kochłowice (CA56), V 2005 - 1 ex., cult. TB [JG]; Ruda Śląska, Lasy Makoszowskie (CA47), 7 VI 1996 - 1 ex., leg. JG; SAC Łęg Zdzieszowicki (BA98), 16 VI 2013 - 1 ex., from a branch of Tilia cordata, reared 1 VII-30 XI 2013, leg. RK; Tworóg (CB30), 22 VI 1992 - 1 ex., leg. HS; Zawiść ad Kluczbork (YS05), 2 II 2008 - 1 ex., under the bark of a fallen trunk of Picea abies, leg. RK. Kraków-Wieluń Upland: Kraków-Las Wolski (DA14), $22 \mathrm{~V}$, year unknown (end of $19^{\text {th }}$ century) - 4 exx., leg. MR [ISEA]. Małopolska Upland: Radom-Las Kapturski (EB09), 22 II 2003 - 1 ex., in the bark of a Tilia cordata branch, leg. MM; SAC "Dolina Zwoleńki", Barycz Stara (EB48), 8 III 2015 - 1 ex., from a branch of a broadleaved tree collected on 28 II 2015, leg. et cult. MM. Roztocze: Florianka [Florjanka] (FB40) - 1 ex coll. FF [MIZ]; Kosobudy (FB41), VI 1941 - 1 ex., Picea abies, in galleries of Scolytinae, ex coll. FF [MIZ]; Roztocze NP, "Nart" strict protection area (FB40), 13 IV 1985 - 1 ex., leg. DK [ISEA]; Nowiny (FA59) - 2 exx., ex coll. FF [MIZ]. Western Sudeten Mts.: Karkonosze, Szklarska Poręba Średnia (WS33), 16-24 VII 1995 - 1 ex., leg. LB [RR]. Eastern Sudeten Mts.: Góry Orlickie, ad Duszniki Zdrój (WR98), 21 X 2012 - 1 ex., reared from a branch of Picea abies (imago: 24 II 2013), leg. AL. Western Beskid Mts.: Babia Góra NP, comp. 17A (CV99), VII 2006 - 2 exx., leg. SSZ [AL]; Silesian Beskids, Barania Góra, Czarna 
Wisełka stream valley (CV59), 18 VIII 1996 - 1 ex., under the bark of Picea abies, leg. RK; Krynica-Kopciowa (DV97), 8 VI 1983, 31 VIII 1984 - 3 exx., leg. DK [ISEA]; Babia Góra massif, Kolisty Groń (CV89), 7 VII 1995 - 1 ex., leg. JG; Wisła Głębce [Głębce] (CV49), 19 VIII 1962 - 3 larvae (imagines: 13 IX 1962), leg. BB; Zawoja-Mosorne (CA90), 5 V 1996 - 1 ex., 5 VII 1996 - 1 ex., leg. JG; Zawoja-Stonów (CA90), V 1996 1 ex., leg. RBO [JG]. Eastern Beskid Mts.: Bekid Niski, for. distr. Dukla, for div. Piotruś, Piotruś Mt., comp. 40, (EV57), 25 VII 2018 - 1 ex., IBL-2 barrier trap with wine, leg. TO; Przemyśl vic. (FA21*) - 4 exx., leg. TT [ISEA]; for. distr. Bircza: Sierakośce for. div., comp. 8a (FA20), 2 V-1 VI 2016 - 1 ex. in an IBL-2 barrier trap, leg. TN [HS]; for. distr. Bircza: Sierakośce for. div., comp. 39a (FV29), 20 V-22 VI 2016 - 1 ex. in an IBL-2 barrier trap, leg. TN [HS]; Turnica for. div., comp. 161c, Suchy Obycz mountain range (FV19), 14 VI-16 VII 2015 - 4 exx., IBL-2 barrier trap, suspended between the boughs of a wind-thrown beech (fallen timber), in the Carpathian beech forest with admixed Norway maple - Acer platanoides L., leg. TN [KR]; Turnica for. div., comp. 180a (FV19), 1-26 VI 2016 - 1 ex., IBL-2 barrier trap, leg. TN [HS]; for. distr. Kańczuga, for. div. Pruchnik, comp. 138c (FA02), $20 \mathrm{~V}-21$ VI 2016 - 1 ex. in an IBL-2 barrier trap, leg. AM [HS]; "Turnica" res. (FV19), 1 VI 2016 - 1 ex., leg. AM [HS]. Nowy Targ Basin: Zakopane, Harenda (DV26), 28 VI 1998 - 1 ex., in flight, leg. RR. Pieniny Mts.: Durbaszka (DV67), $900 \mathrm{~m}$ a.s.l., $8 \mathrm{~V} 2015-1$ ex., in flight, edge of a coniferous forest, leg. AL; Pieniny (DV57), 22 VIII 1958 - 3 exx. [USMB]. Bieszczady Mts. Otryt Mt. (FV15), 14 VIII 2013 - a dozen or so specimens under the bark of spruces Picea abies infested by bark beetles, leg. AM; Otryt Mt., eastern part (FV25), 16 VIII 2013 - 4 exx., on a stack of Picea abies wood, leg. AM.

Distribution. Occurs in north Africa, Europe and the Middle East. Known from the whole of Poland, although it is not a common species. It has recently been recorded in the Białowieża Forest, the Biebrza NP and the Bory Tucholskie forest (GUTOWSKI et al. 2006), fir forests in southern Poland (STARZYK et al. 2008) and north-eastern Poland (HILSZCZAŃSKI et al. 2016). New records from the western Sudeten Mts., eastern Sudeten Mts., Nowy Targ Basin, the Pieniny and Bieszczady Mts. (Fig. 7).

Biology. Larvae and adults feed on the eggs of bark beetles, larvae of wood-boring beetles and other insects. Beetles can be found under the bark of broadleaved and coniferous trees (KOLIBÁČ et al. 2005, this study) throughout the year. They were also observed on vegetation and in flight from the end of April until the end of July. According to the data in Table 1, spruce Picea abies is the preferred tree species overall (54\% of records), and lime Tilia cordata is the preferred deciduous tree species ( $25 \%$ of records). It is plausible that Nemozoma elongatum is predatory on the scolytine Ernoporus tiliae (PANZER, 1793) (MM, unpublished). 


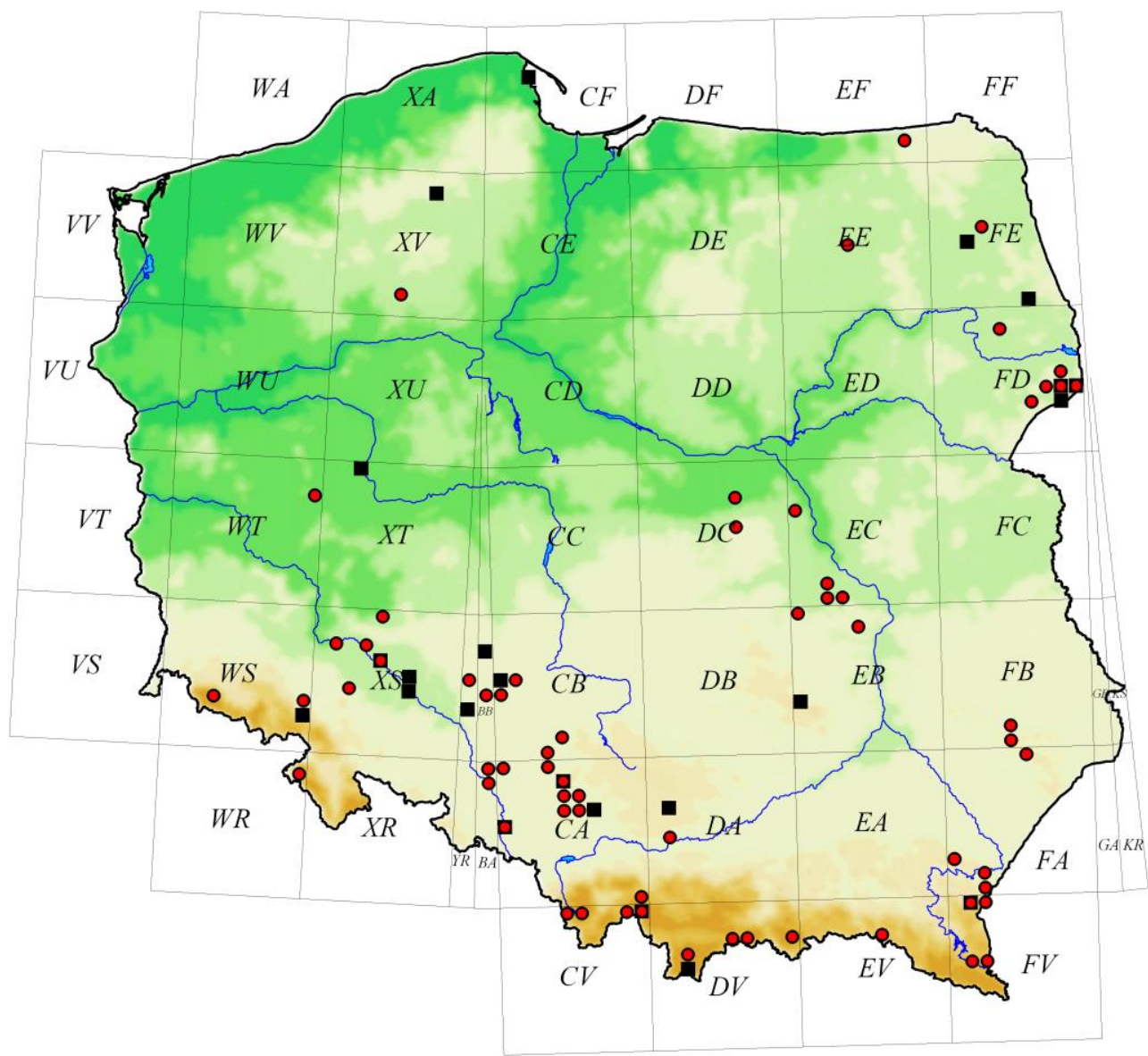

Fig. 7. Nemozoma elongatum (published records - black squares, records reported in the present paper - red circles) - distribution in Poland.

\section{Temnoscheila caerulea (OLIVIER, 1790)}

Material examined. Specimens from Poland are missing from the collections examined.

Distribution. The species is widely distributed in the Mediterranean region, ranging northwards as far as Germany (Bavaria), Poland and Sweden. In Sweden it is known from Gotska Sandön Island (LUNDBERG 1981). There are only two historical records from N Poland (Fig. 2): from the Gdańsk area over 200 years ago (KugELANN 1794) and from Goleniów (KLEINE 1940). 
Table 1. Occurrence of particular beetle species on trees; based on original data. Abbreviations: Nc - Nemozoma caucasicum, Ne - N. elongatum, Tm - Tenebroides mauritanicus, Go - Grynocharis oblonga, Pf - Peltis ferruginea, Pg - P. grossa, $T l$ - Thymalus limbatus, $\mathrm{N}_{\mathrm{s}}-$ total number of species.

\begin{tabular}{|c|c|c|c|c|c|c|c|c|}
\hline \multirow[t]{2}{*}{ Tree genus/species } & \multicolumn{7}{|c|}{ Beetle species } & \multirow[t]{2}{*}{$\mathbf{N}_{\mathrm{s}}$} \\
\hline & $N c$ & $\mathrm{Ne}$ & $T m$ & Go & $P f$ & $P g$ & $T l$ & \\
\hline Abies alba & - & 3 & 1 & 2 & 25 & 29 & 5 & 6 \\
\hline Acer sp. & - & - & 2 & 1 & - & - & 1 & 3 \\
\hline Aesculus hippocastanum & - & - & 2 & 2 & - & - & - & 2 \\
\hline Alnus sp. & - & - & 4 & 1 & 1 & 3 & - & 4 \\
\hline Betula sp. & - & - & 2 & 1 & 2 & 7 & - & 4 \\
\hline Carpinus betulus & - & - & - & 1 & - & - & - & 1 \\
\hline Juglans regia & - & - & - & 1 & - & - & - & 1 \\
\hline Fagus sylvatica & - & - & 2 & 4 & 3 & - & 3 & 4 \\
\hline Fraxinus excelsior & 2 & - & 1 & 1 & - & - & - & 3 \\
\hline Malus sp. & - & - & - & 2 & - & - & - & 1 \\
\hline Quercus sp. & - & 1 & 21 & 16 & 3 & - & 2 & 5 \\
\hline Padus avium & - & - & - & 1 & - & - & - & 1 \\
\hline Philadelphus sp. & - & - & - & 1 & - & - & - & 1 \\
\hline Picea abies & - & 15 & - & 1 & 28 & 3 & 2 & 5 \\
\hline Pinus sp. & - & 1 & - & 5 & 5 & 1 & - & 4 \\
\hline Platanus orientalis & - & - & - & 1 & - & - & - & 1 \\
\hline Populus sp. & - & - & 17 & 12 & 1 & 1 & - & 4 \\
\hline Prunus sp. & - & - & - & 3 & - & - & - & 1 \\
\hline Pyrus sp. & - & - & - & 1 & - & - & - & 1 \\
\hline Robinia pseudoacacia & - & - & - & 1 & - & - & - & 1 \\
\hline Salix sp. & - & - & 1 & 13 & 2 & $\mathrm{v}$ & - & 3 \\
\hline Tilia sp. & - & 8 & - & 2 & 2 & 3 & - & 4 \\
\hline Ulmus sp. & - & - & 6 & - & - & - & - & 1 \\
\hline total number of tree taxa: & 1 & 5 & 11 & 22 & 10 & 7 & 5 & 23 \\
\hline total number of records: & 2 & 28 & 59 & 73 & 72 & 47 & 13 & 290 \\
\hline
\end{tabular}

Biology. Feeds on larvae of Cerambycidae and Buprestidae; usually collected under the bark of dying coniferous trees (JANSSON 1925, BURAKOWSKI et al. 1986). In the Mediterranean region (Greece), found together with larvae of Morimus funereus MULSANT, 1863 on fir (JTD, unpublished). 


\section{Tenebroides mauritanicus (LINNAEUS, 1758)}

Material examined. Baltic Coast: Gdynia (CF34), 19 VIII 1938 - 1 ex., 11 VIII 1939 - 1 ex., leg. AB [MIZ]. Pomeranian Lake District: Szczecin [Stettin] (VV71) - 1 ex., ex coll. Mus. Stettin (Städtisches Naturwissenschaftliches Museum Stettin) [MIZ]. Wielkopolska-Kujawy Lowland: Antonin ad Ostrów Wlkp. (XT91), V 1999-VI 2003 a dozen or so specimens under the bark of an old oak Quercus robur L. growing near a grocery store, leg. AM; Biedrusko vic., military training area (XU32), 24 III $2000-1$ ex., under the bark of a rotting trunk of Betula sp., leg. SK; Dąbrówka ad Poznań (XU10), 28 XII 2015 - 4 exx., under the bark of dead Alnus glutinosa (L.) GAERTN. trees, the edge of an alder forest in an old manor park, leg. SK; Gądków (VT99), 30 VII 1980 - 1 ex., leg. KL [ISEA]; Gołaszyn vic. ad Oborniki, military training area (XU23), 9 IV 2000 - 1 ex., under the bark of a log, bank of an oxbow lake by the River Warta, leg. SK; Gołuchów ad Pleszew (YT04), 9 V 2001 - 1 ex., under the bark of an old oak tree Quercus robur, leg. AM; Grabice vic. ad Luboszyce (VT74), 28 VIII 2011 - 1 ex., under the bark of an old, dying Quercus robur, leg. SK; Lewków ad Ostrów Wlkp., Kwiatkowska Street (XT93), 28 IV $2007-1$ ex. and 5 VII $2009-1$ ex. in feeding galleries of larvae of Cerambyx cerdo LiNNAEUS, 1758 on oak Quercus robur, leg. AM; Łęczyca (CC76) - 2 exx., ex coll. AB [MIZ]; Piła (XU19), 15 V 1998 - 1 ex., leg. RR [ISEA]; Piła-Górne (XU19), 26 III 1997 1 ex., under the bark of a dead Ulmus sp., leg. RR; Piła-Kalina (XU18), 4 V 2001 - 3 exx., under the bark of a fallen oak Quercus sp., leg. RR; Rogalin (XT38), 3 VI 1975 - 1 ex., leg. JŁ [USMB], 20 VI 1998 - 1 ex., under the bark of oaks Quercus sp., 10 II $2002-1$ ex., leg. PJ, 29 VI 2006 - 4 exx., on Quercus sp., leg. SK, riparian forest by the River Warta, 1 VI 2014 - 1 ex., leg. JMG; Rogalin (XT39), 16 VI 1975 - 2 exx., leg. MB [ISEA]; Nowa Sól [Neu Saltz] (WT43), 1 VI 1907 - 3 exx., ex coll. Schreiber [MIZ]; 5 km NE of Skoroszów ad Milicz (XS59), 8 VII 2016 - 1 ex., from dead branches of Fagus sylvatica L., reared 20 VIII-6 IX 2016, leg. RK; Wyspa Krajkowska ad Krajkowo (XT38), 29 IV 2008 - 1 ex., in a rotten trunk near the River Warta, leg. SK. Mazovian Lowland: Buchnik (DD90), 10 III 1968 - 4 exx., leg. BB [MIZ]; Dziekanów Polski (DD80), 24 III 1968 - 1 ex., under the bark of Populus nigra L., leg. BB [MIZ]; Jabłonna near Warszawa (DD90), 21-31 XII 1950 - 9 exx., leg. BB [MIZ]; Łochów (ED42), 20 VIII 1986 - 1 ex., leg. TM [ISEA]; Kozienice Forest, Brzóza, cemetery (EC21), 24 II 1997 - 1 ex., under the bark of a dead Aesculus hippocastanum L., leg. MM; Kozienice Forest, Januszno (EC30), 18 VII 2004 1 ex., under the bark of Populus sp., leg. MM; Kozienice Forest, "Jedlnia" res. vic. (EB29), 16 XII 2012 - 2 exx., under the bark of Quercus sp. damaged by fire, growing on a balk, leg. MM; Kozienice Forest, Kolonia Bąkowiec (EC40), 27 XII 2015 - 1 ex., under the bark of a dead Populus tremula L., leg. MM; Kozienice Forest, for. div. Cztery Kopce (EC31), 15 IV 2005 - 1 ex., under the bark of Quercus sp., leg. MM; Kozienice Forest, Molendy (EC40) - 2 exx., from a dead Betula pendula ROTH trunk, felled on 11 X 2007, leg. et cult. 
MM; Kozienice Forest, "Ponty Dęby" res. (EC20), 11 XI 2014 - 1 ex., under the bark of a dead Quercus sp., 6 I 2018 - 1 ex., in the bark of a rotten Abies alba, leg. MM; Nowy Dwór Mazowiecki, Las Dębinka (DD80), 18 XI 2010 - 1 ex., under the bark of an old Quercus robur, leg. JTD; Obory (EC16), 2 XI 1946 (EC16) - 2 exx., moist alder forest in a swampy area, leg. JMA [MIZ], 14 XII 1947 - 2 exx., leg. RB [MIZ]; Otwock Wielki (EC16), 2 IV 1948 - 2 exx., leg. JPO [MIZ]; Pawłowice vic. Stężyca (EC41), 13 VIII 2009 - 1 ex., under the bark of a dead Ulmus sp., leg. MM; Piaseczno (EC06/EC07), 5 VII 1908 - 3 exx., ex coll. ST [MIZ]; Pomiechówek near Warszawa (DD81) - 1 ex., ex coll. AB [MIZ]; Puławy vic. (EB69), 9 VII 1950 - 3 exx., leg. BB [MIZ]; Serock (ED01), 6 II 1953 - 5 exx., leg. RB [MIZ]; Stężyca vic. Dęblin (EC51), 19 XII 2015 - 1 ex., in crevices of the wood of an old Populus nigra, riparian forest by the River Wisła (Vistula), leg. MM; Warszawa, 6 X 1917 - 2 exx., ex coll. ST [MIZ], 15 IV 1921 - 1 ex., in a flat, ex coll. ST [MIZ], 23 X 1949 - 3 exx., leg. SA [MIZ]; Warszawa-Bielany [Bielany] (DC99), 18 IX 1888 - 2 exx., 25 V 1889 - 1 ex., 14 VI 1895 - 3 exx., 1 VI 1897 - 1 ex., 3 VI 1897 1 ex., 12 VI 1897 - 1 ex., leg. WM [USMB], 22 I 1950 - 6 exx., leg. ZW, 9 XII 1952 1 ex., 20 XII 1953 - 3 exx., under the bark of an oak Quercus sp., 26 IX $1954-2$ exx., 4 II 1959 - 1 larva (imago: 12 VI 1959), 13 VIII 1962 - 1 larva in a pupal chamber, 23 IV 1970 - 1 larva (pupa: 2 VII 1970), leg. BB [MIZ], 13 V 1953 - 1 ex., 8 VII 1948 - 1 ex., leg. JPO [MIZ], 21 II 1950-23 I 1953 - 2 exx., leg. RB [MIZ]; Warszawa-Bielany [Ruda Podleśna ad Warszawa Bielany] (DC99), 24 VII 1930 - 1 ex., under the bark of a poplar or willow, leg. BB [MIZ]; Warszawa, Bielany-Modlin (DD80*), 1 XI 1946 - 4 exx., by a road, under the bark of a poplar Populus sp., leg. JMA [MIZ]; Warszawa-Czerniaków [Warszawa, Czerniaków] (EC08) - 2 exx., JMA [MIZ]; Warszawa, Las Młociński (DC99), 24 III 2016 - 3 exx., under the bark of Alnus glutinosa, leg. JTD, 1 ex., under the bark of Acer platanoides gnawed by a beaver, leg. JTD; Warszawa, "Las Bielański" res. (DC99), 22 III 2008 - 1 ex., under the bark of $Q$. robur, leg. JTD; Warszawa, "Las Natoliński" res. (EC07), 20 V 2019 - 1 ex., on a fallen, almost barkless elm Ulmus sp., overgrown with fungi (after dusk), leg. JTD; Warszawa, "Las Kabacki”" res. (EC07), 23 IV 2010 - 4 exx., under the bark of Quercus robur, 9 IV 2012 - 1 ex., under the bark of Quercus robur, leg. JTD; Szumin (ED33), 12 XI 1990 - 1 ex., 24 VI 1991 - 1 ex., leg. TM [HS]; WarszawaMiedzeszyn (EC18), 11 VI 1956 - 1 ex., on a poplar trunk Populus sp., leg. BB [MIZ]; Warszawa-Młociny [Młociny] (DC99), 18 X 1947 - 2 exx., 28 XI 1952 - 1 ex., under the bark of Aesculus hippocastanum, leg. BB [MIZ]; Warszawa-Młociny [Młociny vic. Warszawa] (DC99), 8 XII 1948 - 3 exx., 28 XI 1952 - 2 exx., leg. RB [MIZ]; Warszawa, Nowogrodzka 48 (EC08), 27 VI-28 VIII 1950 - 7 exx., leg. SA [MIZ]; Warszawa-Radość [Radość ad Warszawa] (EC18), $30 \mathrm{~V} 1955$ - 1 ex., in a packet of cottage cheese, leg. EK [MIZ]; Warszawa-Saska Kępa [Saska Kępa] (EC08), 5 XII 1948 - 3 exx., leg. JMA [MIZ]; Warszawa-Wawer [Wólka Żerzeńska ad Warszawa] (EC08), 10 IV 1939 - 1 ex., ex coll. 
ST [MIZ], 1 XII 1957 - 2 exx., in rotten poplar wood Populus sp., leg. BB [MIZ]; Zegrze, during a flood of the River Narew (ED01), 14 III 1948 - 2 exx., leg. RB [MIZ]; Zegrze (ED01), 14 III 1948 - 1 ex., leg. ADAMSKI (?) [MIZ]. Białowieża Primeval Forest: Białowieża NP, Hwoźna river valley [former for. distr. Browsk] (FD95), 20 III 1952 4 exx., leg. BB [MIZ]; Białowieża NP [former for. distr. Browsk], comp. 192 (FD95), 23 IV 1968 - 1 larva (pupa 17 VII 1968), leg. BB [MIZ]; Białowieża NP, comp. 224 (FD95), 3 VI 1954 - 1 ex., leg. BB [MIZ]; Białowieża NP, comp. 288C/318A (FD94), mixed coniferous forest, 11 V 2011 - 1 ex., in an IBL-2bis barrier trap, leg. JMG; Białowieża, Palace Park ("Park Pałacowy") (FD94), 8 XI 2003 - 1 ex., leg. MM [JMG]; Guszczewina vic., comp. 62B (FD85), 21 III 2013 - 1 ex., reared from a small branch of Quercus sp., leg. JŁ [AL]; Hajnówka vic., comp. 412 (FD74), 22 IV 2006 - 1 ex., alder forest, on a bracket fungus, leg. AL; for. distr. Browsk, comp. 15B (FD96), 28 III 2014 - 1 ex., under the bark of a dead trunk of Populus tremula, 1-15 VIII 2014 - 1 ex., reared from a rotting trunk of Populus tremula, leg. RK; for. distr. Browsk, comp. 63B (FD95), 25 IV 2013 - 1 ex., leg. JŁ [RK]; Białowieża NP, comp. 282B (FD85), 25 VII-8 VIII 1996 - 1 ex., in an IBL-2bis barrier trap, leg. JMG [ISEA]; for. distr. Hajnówka, Nowosady vic., (FD75), 15 X $2010-$ 1 ex., under the bark of Quercus robur (of $90 \mathrm{~cm}$ diameter), leg. ABO, det. et coll. JMG; Białowieża-Krzyże vic. (FD94), 18 V 2017 - 1 ex., on the trunk of an oak Quercus sp. overgrown with fungi (at night), leg. JTD; Białowieża-Krzyże vic. (FD94), 11 III 2014 1 ex., from a piece of thick $(4-5 \mathrm{~cm})$ oak bark collected on 12 X 2013, leg. et cult. JTD; comp. 523C (FD83), 28 IV 2009 - 1 ex., under the bark of Populus tremula, leg. JTD. Lower Silesia: Malczyce (XS07) [Maltsch] - 5 exx., ex coll. GP [MNHW]; Szewce vic. Wrocław (XS37), 12 XI 1978 - 2 exx., ex coll. AEBG [MNHW]; Wałbrzych (WS92), 1950 - 1 ex., leg. SKA [ISEA]; Wrocław-Osobowice (XS37), 14 VII 1984 - 1 ex., ex coll. AEBG [MNHW]; Wrocław-Rędzin (XS37), 2 VI 1991 - 5 exx., leg. LB [RR]; WrocławŚwiniary (XS37), 27 IV 1991 - 6 exx., 1 V 1996 - 1 ex., leg. LB [RR], 5 V 1991 - 1 ex., leg. MW; Wrocław-Wojnów (XS56), 18 IV 1993 - 4 exx., 15 V 1997 - 3 exx., leg. LB [RR], 22 IV 2003 - 1 ex., leg. AG, ex coll. AEBG [MNHW], 8 IV $2006-1$ ex., under the bark of an old oak Quercus sp., leg. RR, 7 II 2009 - 1 ex., leg. RR, 1 V 2011 - 1 ex., leg. RK; Wrocław-Zakrzów (XS46), 15 IX 1991 - 2 exx., leg. LB [RR]; Wrocław, near the zoo, by the River Odra (XS46), 12 VII 1989 - 1 ex., dead in a spider's web on an oak Quercus robur, leg. RK. Trzebnica Hills: Borowa Oleśnicka (XS57), 9 IV 1972 - 2 exx., 24 III 1973 - 1 ex., 17 VI 1978 - 1 ex., 8 X 1984 - 1 ex., ex coll. AEBG [MNHW], 25 V 1991 1 ex., 7 VI 1991 - 1 ex., under the bark of Quercus robur, leg. RK; Głogówek (YR08), 21 VIII 2005 - 2 exx., leg. JG. Upper Silesia: Baranowice (CA34), 10 V 2009 - 1 ex., 25 V 2014 - 1 ex., leg. TB \& JG; Brzezinka [Sil. Birkenau, Oberschlesien] (CA27), 15 XI 1935 - 1 ex., leg. KK, ex coll. GP [MNHW]; Brynek (CA39), 8 VIII 1930 - 1 ex., leg. HN [USMB]; Bytom (CA57), 23 VI 1925 - 1 ex., in peanuts, leg. HN [USMB]; Chełmek 
(CA75), 13 IV 1879, 1 VII 1880, 10 IV 1881 - 12 exx., leg. SAS [ISEA]; Jaworzno (CA76), 8 VII 1910 - 1 ex., leg. SAS [ISEA], 12 IV 1925 - 1 ex., leg. KS [USMB]; Konopiska (CB52), 14 VI 1998 - 2 exx., leg. TK [JG]; Korzonek (CA07), 13 VI 1998 1 ex., leg. JG; Las Murckowski (CA56), 12 VII 2010 - 1 ex., at light, 7 VII 2014 - 1 ex., leg. JG; Łężczok (CA06), 6 VII 2006 - 1 ex., leg. JG; Murcki (CA66), 21 V 1930 - 1 ex., leg. HN [USMB]; Ruda Śląska-Wirek (CA47), 5 I 1993 - 1 ex., in a larder, 3 I 1998 1 ex., 6 VIII 2015 - 1 ex., at light, leg. JG; Ruda Śląska-Wirek, near Szpitalna Street (CA47), 2 IV 1991 - 1 ex., dead in flour, leg. JG [RK]; Rudziniec Gliwicki (CA18), VI 1994 - 1 ex., 29 VIII 1998 - 1 ex., leg. JG. Kraków-Wieluń Upland: Kraków (DA14), 10-27 VIII 1917, VIII 1923 - 6 exx., leg. SP [ISEA], 7 VIII 1920 - 1 ex., VII 1923 - 1 ex., ex coll. EM [MIZ], 26 VI 1947 - 1 ex., in a flat, 14 VI 1948 - 1 ex., in a flat [USMB]; Kraków-Tyniec (DA14), 24 V 1972 - 1 ex., leg. AS [ISEA]; Kraków-Wola Justowska (DA14), 30 IV 1878 - 1 ex., leg. SAS [ISEA]; Wieliczka (DA33) - 1 ex., leg. EM [MIZ]. Małopolska Upland: Jedlanka vic. Jedlińsk (EC00), 5 VI 1998 - 1 ex., under loose bark of Ulmus sp. growing on a roadside, leg. MM; Jedlińsk vic. Radom (EC00), 20 III $2005-$ 1 ex., under the bark of Populus sp., 26 XI 2017 - 2 exx., under the bark of Populus sp. overgrown with Pleurotus ostreatus (JACQ.) P. KUMM. on the bank of the River Radomka, leg. MM; Przedbórz, park (DB26), 27 VI 2012 - 1 ex., under the bark of Ulmus sp., leg. MM; Radom-Firlej (EB19), 2 XI 2014 - 1 ex., under the bark of Acer sp. near the River Mleczna, 3 XII 2017 - 1 ex., under the bark of Populus sp. overgrown with Pleurotus ostreatus on bank of the River Mleczna, 18 III 2018 - 1 ex., in bark of a dead Ulmus laevis PALL. on a roadside, with numerous galleries of Scolytus sp., leg. MM; Radom-Huta Józefowska (EB19), 29 I 2015 - 1 ex., in crevices of the bark of an old Populus sp., leg. MM; Radom-Józefów (EB19), 16 VI 2005 - 1 ex., under the bark of Populus sp., leg. MM; Radom-Nowa Wola Gołębiowska (EB19), 30 VII 2004 - 1 ex., under the bark of Populus sp., leg. MM; Ruda Wielka vic. Wierzbica (EB08), 12 III 2017 - 1 ex., under the bark of a dead Populus sp., by the pond, leg. MM; SAC "Dolina Zwoleńki", Zielonka Nowa (EB48), 14 III 2014 - 1 ex., under the bark of a dead Alnus glutinosa on a bank of the River Zwoleńka, leg. MM; SAC "Dolina Zwoleńki”, Zielonka Nowa vic. (EB48), 10 VI 2018 1 ex., under the bark of a dead Salix fragilis L. on a bank of the River Zwoleńka, leg. JMG; Stromiecka Forest ("Puszcza Stromiecka"), Dobieszyn (EC11), 8 XII 2018 - 2 exx., under the bark of a dead Alnus glutinosa in an alder carr, leg. MM; Zwoleń, Partyzantów Street (EB48), 3 I 2015 - 1 ex., under the bark of Populus sp., leg. MM; Żdżary vic. Błotnica Stara (EC01), 27 I 2018 - 2 exx., under the bark of a dead Ulmus sp., riparian forest in the Tymianka river valley, leg. MM. Lublin Upland: Kazimierz Dolny [Kazimierz n/W.], 13 V 1949 - 1 ex., (EB68), leg. AR [MIZ]; ad Puławy, Wólka Gołębska vic. (EC60), riparian forest by the River Wisła (Vistula), 11 II 2017 - 1 larva and 1 adult under the bark of dead, standing poplars Populus alba L. of 30 and $35 \mathrm{~cm}$ diameter, leg. JMG; Puławy, Park 
Czartoryskich (EB69), 9 XII 2017 - 6 exx., overwintering under the bark of a broken Acer platanoides, leg. JMG. Roztocze: Roztocze NP, "Czerkies" strict protection area (FB40), 8 VI 1988 - 1 ex., leg. LB [RR]; Roztocze NP., "Nart” res. (FB40), 3 VII 1997 - 1 ex. in beechwood Fagus sylvatica, leg. AM. Sandomierz Lowland: Horyniec Zdrój [Horyniec] (FA66), $20 \mathrm{~V} 1888$ - 1 ex., leg. SAS [ISEA]; Malinie, historic park, (EA37), 24 IV-28 VII 2016 - 1 ex., reared from a fallen Fraxinus excelsior branch, leg. MKS [TO]; for. distr. Nowa Dęba, for. div. Lipie, comp. 145 (EA58), 11 V 2011 - 1 ex., mixed coniferous forest, on a stack of pine wood, leg. TH [MM]; Tarnów Młyn (DA94), 17 XII 1956 - 1 ex., leg. WB [MIZ]. Eastern Beskid Mts.: Bircza (FA00), Panieński Czub Mt., 4-22 V 1879 4 exx., leg. BK [ISEA]; Hołubla (FA11), 25-31 V 1884, 15 VI 1884 3 exx., leg. BK [ISEA]; Krosno (EA50), III 1950 - 1 ex., in a cellar, leg. AG [USMB]; Łętownia (FA21), Kaczmarowa Mt., 28 IV 1879 - 2 exx., leg. BK [ISEA]; Magura NP: Hałbowska Pass (EV38), 10 V-10 VI $2014-1$ ex., in an IBL-5 barrier trap suspended from a fir snag, leg. AM; ad Ciechania (EV37), 10 V-10 VI 2014 - 1 ex., in an IBL-5 barrier trap hanging from a beech tree trunk, leg. AM; Olszany (FA11), 7 VI $1884-1$ ex., leg. BK [ISEA]; Przemyśl (FA21), VII 1935 - 2 exx., leg. SP [ISEA]; Przemyśl vic. (FA21*), 24 exx., leg. TT [ISEA]; Spława Mt. (FA10), 7 VI $1884-3$ exx., leg. BK [ISEA]; Bekid Niski, for. distr. Rymanów, for. div. Lipowiec, comp. 155, (EV57), 23 VII 2012 - 1 ex, under the bark of Fagus sylvatica, 1 ex., leg. TO. Bieszczady Mts.: Bystre ad Baligród (EV96), 28 XII 2015 - 1 ex. in a flat, leg. AM; Jabłonki ad Cisna (EV95), 23 VII 2015 1 ex. at light, leg. AM et TO.

Distribution. This species occurs in Europe and north Africa in nature, and is cosmopolitan under synanthropic conditions, e.g. in grain stores. There are some doubts regarding its taxonomic status. According to KoliBÁČ 2013, it occurs in two forms: a synanthropic one and a free-living (forest) one, known in older papers as Tenebroides fuscus (GOEZE, 1777). BURAKOWSKI et al. (1986) described the forest form as very rare, even a relict of primeval forests. One can infer from the data gathered in the present paper that the forest form is common in the Polish lowlands, where it prefers forests in river valleys and avoids submontane and montane areas. The species has recently been recorded in Wrocław (BOROWIEC 2007) co-occurring with Camponotus truncatus (SPINOLA, 1808) ants; also recorded in Upper Silesia by GRZYwOCZ \& SzOŁTYS (1996) and MELKE \& GRZYwOCZ (2003). New records from the Trzebnica Hills, Lublin Upland, Roztocze, Sandomierz Lowland and Bieszczady Mts. (Fig. 8).

Biology. The species occurs right across the country with the exception of submontane and montane areas. The forest form is recorded in areas where old, dying or dead trees are present. It is observed in riverine forests, roadside avenues and parks. The beetles occur under the bark of numerous deciduous trees, especially oaks (BURAKOWSKI et al. 1986), 


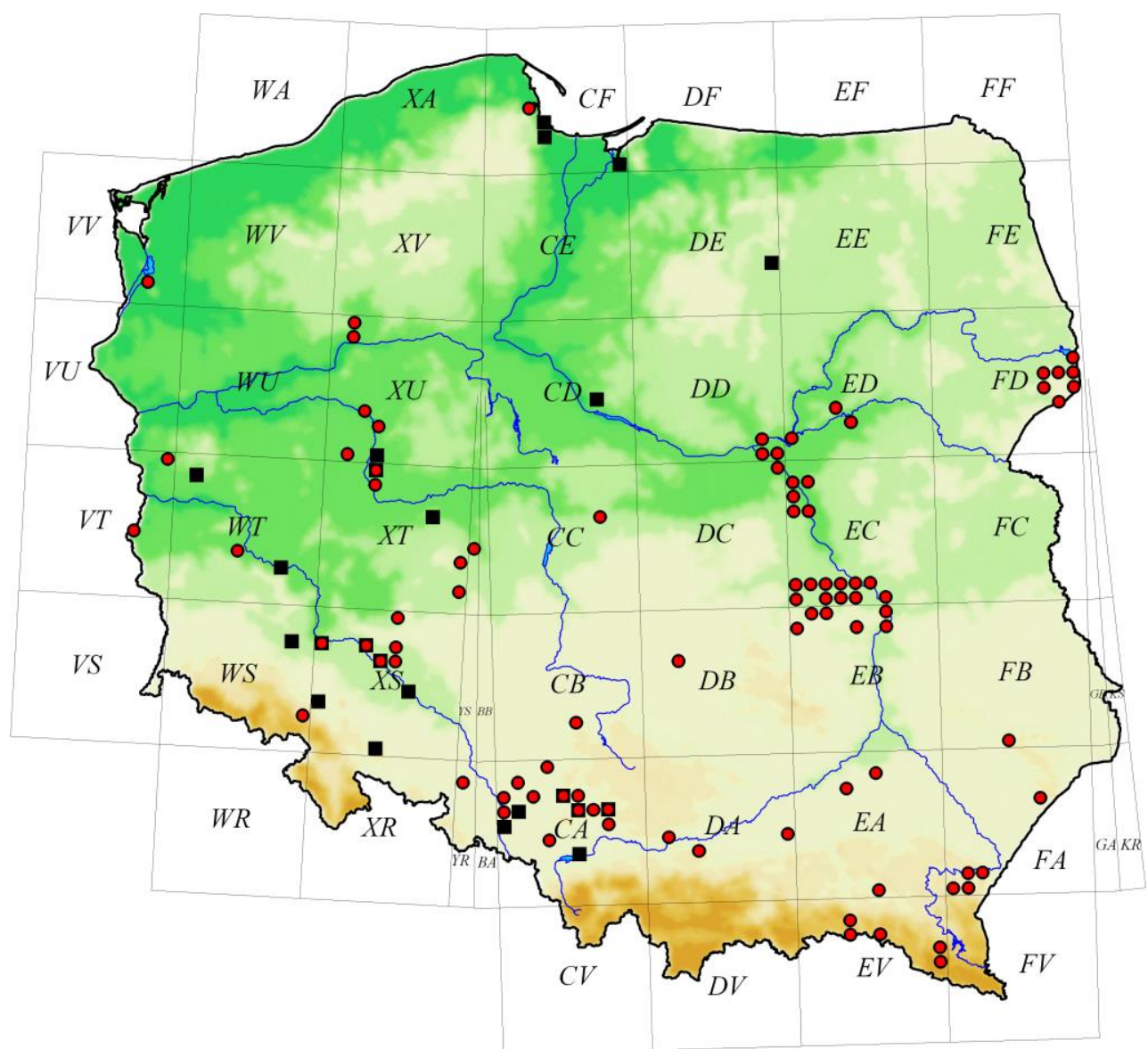

Fig. 8. Tenebroides mauritanicus (published records - black squares, records reported in the present paper - red circles) - distribution in Poland.

and occasionally coniferous ones, e.g. firs. This is confirmed by the data in the present paper - the species prefers oaks (36\% of records) and various species of poplars (29\% of records). Even dead and barkless trees are inhabited. Adults overwinter under bark, in its crevices, or in abandoned galleries of other insects. The beetles are encountered throughout the year, although they are also seen away from the host trees from the end of April until the beginning of August; adults are also attracted to artificial light sources.

Pupation was observed in July. Beetles of the forest form are predators on trees (KoLIBÁČ et al. 2005), whereas beetles of the synanthropic form are pests of stored products and are only occasionally predatory.

\section{Family: Lophocateridae}




\section{Grynocharis oblonga (LINNAEUS, 1758)}

Material examined. Pomeranian Lake District: Drawieński NP, Półwysep Dębowy (WU68), 8 VI 2000 - 1 ex., under the bark of a dying pine Pinus sp., obs. RR; Koszalin (WA70) [Pommern, Coeslin] - 4 exx., leg. ALU [MIZ]; Piła-Gładyszewo vic. (XU19), 8 VI 1997 - 1 ex., in the rotten wood of an old willow tree Salix sp., 1 IV 1999 - 3 exx., in the rotten trunk of a poplar, leg. RR; Rokitnica (CF41) [Müggenhahl, Danzig] - 1 ex., ex coll. PF [MIZ]; Zawada vic. (XU09), 18 III 2000 - 1 ex., under the bark of an old poplar Populus sp., leg. RR. Masurian Lake District: Brodnica (CE90), 6 VIII 1960 - 1 pupa (imago: 10 VIII 1960), leg. et cult. BB [MIZ]; Gołdap (EF81), 13 VI 1953 - 1 ex., leg. ZSP [RP], 28 III 1955 - 1 ex., in white rot on a willow Salix sp., leg. BB [MIZ]; Pisz Forest, Pogobie Średnie vic., "Szast" reference forest (EE53), pine forest, 19 V-10 VI 2015 2 exx., in IBL-2bis barrier traps, leg. JMG; Sztynort (EE49), 9 VIII 1958 - 1 larva (imago: 24 VII 1959), leg. et cult. BB [MIZ]; "Mazury" res. (EE79), 8 IX 2018 - 1 dead ex., under the bark of an old, dead oak Quercus sp., leg. MM. Wielkopolska-Kujawy Lowland: "Buczyna Szprotawska" res. (WT40), 19 V 2007 - 1 ex., obs. RR \& KZ; Czerniejewo ad Gniezno (XU61), manor park, 12 XI 2013 - 2 exx., leg. JMG; "Dębowiec" res. near Gubin (VT95), 25 VI 2011 - 1 ex., obs. SK; Goraj ad Czarnków (XU05), 26 V 2007 - 1 ex., on an old beech Fagus sylvatica close to a road leading to the technical school, leg. RR; KaliszChmielnik (CC03), $28 \mathrm{~V} 1982-1$ ex. in a hollow of a walnut Juglans regia L. in an orchard, leg. AM [ISEA]; 5 VI $2004-1$ ex., under the bark of an old apple tree Malus sp., leg. AM; Kalisz, city park (BC93), 19 IV $2001-1$ ex., on the barkless lesion of an oak Quercus robur, leg. AM; Kalisz-Szczypiorno (BC93), 12 V 1997 - 1 ex., in an oak tree hollow Quercus sp., leg. AM; Luboszyce vic. (VT84), 28 VIII 2011 - 1 ex., under the bark of an old Quercus robur, the edge of a meadow, leg. SK; Lusowo (XU11), 3 V 1998 2 exx., under the bark of Salix sp., 1 V 1999 - 1 ex., under the bark of Salix sp., 27 III 2004 - 1 ex., under the bark of Salix sp., 12 IV $2004-1$ ex., under the bark of Populus sp., $\mathrm{N}$ bank of Lake Lusowskie, leg. SK; Łęczyca (CC76) - 3 exx., ex coll. AB [MIZ]; Obrzycko vic. ad Zielonagóra (XU04), 19 VI 1997 - 1 ex., in rot on a Quercus sp., bank of the River Warta, leg. SK; Olszyna ad Ostrzeszów (YS09), 20 V 2010 - 3 exx., on Padus avium MiLL. blossoms, leg. AM; Poznań, park Cytadela (XU30), 23 VIII 1998 - 1 ex., under the bark of Robinia pseudoacacia L., 22 II 1999 - 1 ex., under the bark of Populus sp., leg. SK; Poznań, ad Lake Maltańskie (XU30), 14 VI 2004 - 2 exx., sticky trap on pine Pinus sylvestris, leg. SK; Puszczykowo ad Poznań (WT97), 7 V 1994 - 1 ex., under the bark of a young pine Pinus sp., leg. PJ; Radojewo vic., military training area (XU21), 25 IX 1998 - 1 ex., under the bark of a decaying Betula sp., on the bank of Lake Glinowieckie, leg. SK; Rogalin (XT39), 16 VI 1975 - 2 exx., leg. MB [ISEA]; Rogalin vic. (XT38), pine forest on moraine, 10 II $2001-2$ exx., under the bark of a pine Pinus sp., leg. PJ, 11 II 2001 - 1 ex., leg. SK; Ruda Milicka (XT61),14 V 1983 - 1 ex., leg. LB [RR]; Sycyn ad 
Szamotuły (XU03), 3 V 2004 - 1 ex., leg. SK. Mazovian Lowland: Brok nad Bugiem (ED54), 24 VI 1990 - 1 ex., leg. DK [ISEA]; Brwinów (DC87), 21 V 1953 - 3 exx., 17 V 1954 - 1 ex., leg. AR [MIZ]; Celestynów near Warszawa (EC26), 28 V 1950-4 V 1952 4 exx., leg. BB [MIZ]; Chylice (EC06), 5 V 1910 - 1 ex., ex coll. ST [MIZ]; Grodzisk Mazowiecki - Piaskowa (DC77), 16 V $1971-1$ ex., under a dry fungus on a cherry tree Prunus sp., leg. BB [MIZ]; Grodzisk Mazowiecki (DC77), 3 V 1934 - 1 ex., ex coll. ST [MIZ]; Jabłonna (DD90), 1 XI 1955 - 1 larva (dead imago: 10 XI 1956), leg. BB [MIZ]; Jedlnia (EC20), 5-8 VI 1995 - 1 ex., leg. HS; Kacice (ED03), 24 III 1955 - 2 exx., in a rotting poplar Populus sp. at a height of $13.5 \mathrm{~m}$, leg. BB [MIZ]; Kędzierak (EC37), 31 X 1954 - 1 ex., leg. BB [MIZ]; Leszno (DC78), 27 IV 1952 - 1 ex., under the bark of a willow Salix sp., leg. BB [MIZ]; Lipce (DC25), 20 XI 1955 - 1 ex., in the wood of a beech Fagus sylvatica overgrown with fungi, leg. BB [MIZ]; Łomianki (DC99), 6 V 1956 - 1 ex., under the bark of a willow, leg. BB [MIZ]; Magdalenka (DC97), 21 XI 1954 1 ex., under the bark of an oak Quercus sp., leg. BB [MIZ]; Natolin (EC07), 14 VI 1893 1 ex., leg. WM [USMB]; Otwock [Jabłoń] (EC17), 1 VII 1901 - 1 ex., leg. WM [USMB]; Otwock-Świder [Świder] (EC17), 4 VII 1903 - 1 ex., leg. WM [USMB]; Otwock-Świder [Świder n. Wisłą] (EC17), 6 IV 1952-25 VI 1952 - 3 exx., leg. BB [MIZ]; Podkowa Leśna (DC87), 10 VI 1955 - 1 ex., leg. JPO [MIZ]; Pomiechówek (DD81) - 1 ex., ex coll. AB [MIZ]; Kampinos Forest ("Puszcza Kampinoska"), Dąbrowa (DC79), 18 I 1953 - 1 ex., in rot on a cherry tree Prunus sp., leg. BB [MIZ]; Kampinos Forest, Dziekanów Leśny (DD90), 7 IV 1963 - 1 larva (imago: 3 V 1966), leg. et cult. BB [MIZ]; Kampinos Forest, Lawy near Pruszków (DC79), 18 I 1959 - 2 exx., beetles in copula, in rot on a lime tree Tilia sp., leg. BB [MIZ]; Kozienice Forest, "Jedlnia" res. (EB29), 15 VI 2011 - 1 ex., on the trunk of an old, dead Quercus sp., leg. MM; Kozienice Forest, Pionki vic. (EC30), 27 V 2017 - 1 ex., on the trunk of a rotting Quercus sp., leg. MM; Kozienice Forest, Siczki (EB29), 15 IV 1994 - 1 ex., under the bark of Populus tremula at the edge of the forest, 16 IV 2011 - 2 exx., on a trunk of a dead Quercus sp., leg. MM; Raszyn (DC97), 16 VI 1895 1 ex., leg. WM [USMB]; Siennica (EC47) - 1 ex., ex coll. AB [MIZ]; Stary Otwock (EC17), 13 VI 1928 - 1 ex., under the bark of an oak Quercus sp., ex coll. ST [MIZ]; Urle (ED41), 11 VI 1902 - 1 ex., leg. WM [USMB]; Warszawa (EC08), 19 IV 1911 - 1 ex., leg. WM [USMB]; Warszawa-Anin (EC18), 27-30 IV 1949 - 1 ex., leg. WD [MIZ]; Warszawa-Białołęka [Piekiełko] (DC99) - 1 ex., ex coll. ST [MIZ]; Warszawa-Bielany [Bielany] (DC99), 18 VI 1888 - 1 ex., 4 VII 1888 - 2 exx., 5 V 1889 - 1 ex., 1 VI 1889, 5 VI 1889 - 1 ex., 4 V 1894 - 2 exx., 27 VI 1898 - 1 ex., leg. WM [USMB], 18 IV $1953-$ 1 ex., leg. AMA, ex coll. WE [MIZ], 24 V 1951-26 XII 1963 - 10 exx., leg. BB [MIZ]; Warszawa-Grochów (EC08), 27 VII 1933 - 1 ex., on a willow Salix sp., leg. BB [MIZ]; Warszawa, "Las Kabacki" res. (EC07), 1 III 2017 - 1 ex., under the bark of a hornbeam Carpinus betulus L. overgrown with fungi, leg. JTD; Warszawa, "Las Kabacki" res. 
(EC07), IV 2018 - 2 exx., on a dead Pinus sylvestris overgrown with fungi (after dusk), leg. JTD; Warszawa, "Las Natoliński” res. (EC07), 30 V 2017 - 1 ex., on a dead oak Quercus sp. (after dusk), leg. JTD; Warszawa-Łazienki [Łazienki] (EC08), 28 IV 1918 - 1 ex., ex coll. ST, 22 IV 1930 - 1 ex., ex coll. ST [MIZ]; Warszawa-Młociny (DC99), 13 I 1952 4 exx., leg. BB [MIZ]; Warszawa-Morysin [Morysinek] (EC07), 5 XII 1954-19 VI 1955 6 exx., 7 VIII 1955 - 1 ex., from a pupa collected in white rot on a willow Salix sp. (imago: 25 VIII 1955), leg. BB [MIZ]; Warszawa-Natolin (EC07), 25 VI 2016 - 1 ex., leg. JTD; Warszawa, Zoological Garden (EC08), 1 VII 1940 - 1 ex., leg. BB [MIZ]; Warszawa, Młociny Park (DC99), 25 X 1953 - 1 ex., a larva in white rot on a lime tree Tilia sp. (imago: 23 IX 1954), leg. BB [MIZ]; Warszawa-Pyry (EC07), 20 IV 1948 1 ex., leg. BB, 8 IV 1951 - 1 ex., leg. BB [MIZ]; Warszawa-Saska Kępa [Saska Kępa] (EC08), 20 VI 1893 - 1 ex., 31 V 1901 - 1 ex., leg. WM [USMB], 7 V 1957 - 1 ex., poplar Populus sp., leg. JPO [MIZ]; Warszawa-Służew [Służew] (EC08), 17 V 1888 - 1 ex., leg. WM [USMB]; Warszawa-Ursynów [Pyry] (EC07), 3 V 1933 - 1 ex., ex coll. ST [MIZ]; Warszawa-Wawer [Wólka Żerzeńska ad Warszawa] (EC08), 1 XII 1957 - 1 ex., in the trunk of a poplar Populus sp., leg. BB [MIZ]; Warszawa-Wilanów [Zawady nad Wisłą] (EC07), 15 V 1955 - 2 exx., in copula, under the bark of a rotting poplar Populus sp., leg. BB [MIZ]; Warszawa-Włochy [Salomea] (DC98), 12 V 1931 - 1 ex., ex coll. ST [MIZ]; Zaryte (EC63) - 2 exx., ex coll. ST [MIZ]; Zegrze (ED01), 27 IV 1935 - 1 ex., ex coll. ST [MIZ]; Zielonka (EC19) - 1 ex., ex coll. ST [MIZ]; Zielonka ad Warszawa (EC19), 28 IV 1957 - 1 ex., leg. BB [MIZ]. Podlasie: Jeńki (FD27), 9 V 2013 - 1 ex., leg. AL; Mordy vic. Siedlce (FC08), 22 VI 1991 - 1 ex., leg. DK [ISEA]; Knyszyn Forest, "Las Cieliczański" res. (FD59), oak-hornbeam forest, 14 IV 2010 - 3 exx., under the bark of a broken Acer platanoides, ca. $100 \mathrm{~cm}$ in diameter, leg. JMG; Wyszonki-Błonie (FD14), 2 V 2003 - 1 ex., on a wooden pole, at night, leg AL. Bialowieża Primeval Forest: Białowieża NP, ad Gruszki, comp. 105B (FD95), burned site, 11-17 V 2017 - 1 ex., 22 V5 VI 2017 - 1 ex., in a black, baited funnel trap, leg. JMG; Białowieża NP, comp. 288C/318A (FD94), mixed coniferous forest, Calamagrostio-Piceetum, 17 VI $1998-1$ ex., 2 VI 2005 - 1 ex., 10 V 2007 - 1 ex., in IBL-2bis barrier traps, leg. JMG; Białowieża NP/for. distr. Białowieża, Droga Browska, comp. 375B/375D (FD94), 13-19 V 1997 1 ex., 27 V-2 VI 1998 - 2 exx., 3-9 V 2000 - 1 ex., in IBL-2bis barrier traps, leg. JMG; Białowieża, Browska Street, 27 V 2012 - 2 exx., in the rotting hollow of a Quercus robur, leg. JTD; Białowieża, Palace Park (FD94), 27 III 1949 - 1 ex., leg. ZW [MIZ], 20 V 1982 1 ex., 8 V 1993 - 1 ex., 18 V 1993 - 2 exx., leg. MW; Białowieża (FD94), 9 V 1993 1 ex., leg. MW; for. distr. Browsk, comp. 15D (FD96), 27 III, 2014 - 1 ex., leg. JŁ [AL]; for. distr. Browsk, comp. 75 (FD75), 9 XII 2008 - 1 ex., leg. JŁ [AL]; for. distr. Browsk, comp. 121C (FD85), 23 IV 2008 - 1 ex., in a dead, thick Populus tremula, leg. JŁ [RK]. Lower Silesia: Chojnów (WS68), 28 XI 1950 - 1 ex., reared from a white bracket fungus, 
leg. BB [MIZ]; Dunino [Dohnau, Kr. Liegnitz] (WS76), IV 1895 - 1 ex., leg. RS [MNHW], IV 1925 - 2 exx., ex coll. WK [MNHW]; Piszkawa ad Oleśnica (XS66), 15 VI 1978 1 ex., ex coll. AEBG [MNHW]; Wrocław (XS46), 18 IV 1988 - 1 ex., leg. BG, ex coll. AEBG [MNHW]; Wrocław [Breslau] (XS46), V 1925 - 1 ex., 20 VI 1930 - 2 exx., VI 1930 - 4 exx., ex coll. GP [MNHW]; Wrocław-Opatowice (XS46), 4 VI 1988 - 1 ex., leg. BG, ex coll. AEBG [MNHW]; Wrocław-Świniary (XS37), 1 V 1996 - 1 ex., leg. LB [RR]; Wrocław-Wojnów (XS56), 8 IV 2006 - 1 ex., under the bark of an old oak, leg. RR; Zimna Woda (WS78) [Kaltw.] - 1 ex., ex coll. WK [MNHW]. Upper Silesia: Brynek (CA39), 17 V 1992 - 1 ex., leg. JG; Brynek (CA39), 20 V 1990 - 1 ex., 5 V 1992 - 2 exx., 17 V 1992 1 ex., 3 V 1993 - 6 exx., 13 IV 2008 - 2 exx., 24 III 2012 - 1 ex., leg. HS; Bytom, Las Segiet (CA38/48), 17 V 1997 - 1 ex., 2 IV 2011 - 1 ex., leg. JG; Bytom (CA57), 8 XII 1944 - 1 ex., leg. FK [USMB]; Chełmek (CA75), 21 IV $1878-1$ ex., 28 IV $1882-1$ ex., leg. SAS [ISEA]; Góra św. Anny LP, Czarnocin (CA09), 26 V 2005 - 1 ex., leg. JG; Dąbrowa Górnicza (CA77), 22 VI 1938 - 1 ex., leg. KS [USMB]; Jaworzno-Szczakowa (CA76), 26 V 1911 - 1 ex., leg. SP [ISEA]; for. distr. Kluczbork, for. div. Zameczek, comp. 142 (BB94), 19 III 2001 - 1 ex., under the bark of Fagus sylvatica, leg. RK; Korzonek (CA07), 9 VI 2013 - 1 ex., leg. JG; Lasowice Małe ad Kluczbork (CB04), 11 V 1993 - 1 ex., in a spider's web on Quercus robur, leg. RK; Łężczok (CA05), 23 VI 2011 - 1 ex., leg. JG; "Łężczok" res. ad Racibórz (CA05), 24 IX 2015 - 1 ex., under the bark of an old trunk of Quercus robur, leg. RK; Mikołów-Chudów (CA46), 24 VI 2005 - 1 ex., leg. JG; Mikołów-Paniowy (CA46), 3-10 VI 1996 - 5 exx., 14 V 1997 - 5 exx., leg. JG; Połomia (CA39), 28 III 2004 - 1 ex., leg. HS; Ruda Śląska, Lasy Bielszowskie (CA47), 27 IX 2015 - 1 ex., leg. JG; Rudziniec Gliwicki (CA18), 8 V 1994 - 1 ex., leg. JG; "Segiet" res. (CA48), 2 V 2008 - 1 ex., 5 IV 2009 - 2 exx., leg. HS; Święciny vic. Kluczbork 1 km E (YS14), 23 IV $2005-1$ ex., in an old fruiting body of Fomes sp. on Fagus sylvatica, leg. RK; Tarnowice St. (CA48), 6 VI 2000 - 1 ex., leg. JG; Tuły vic. Kluczbork, (BB94), 16 IV 1998 - 1 ex., in rot on Quercus robur, leg. RK; Wilkowice (CA48), 6 VI $1996-1$ ex., leg. JG. Kraków-Wieluń Upland: Czatkowice (DA05), 30 VIII 1915 - 1 ex., leg. SAS [ISEA]; Kraków (DA24) - 2 exx., ex coll. EM [MIZ]; Kraków-Dębniki (DA14), 1-8 V, year unknown (late $19^{\text {th }}$ century) -4 exx., leg. MR [ISEA]; Kraków, Botanical Garden (DA24), 30 IV 1936 - 1 ex., 10-13 VI 1936 - 4 exx., 4 VI 1937 - 4 exx., 19 VI 1939 - 3 exx., leg. SP [ISEA]; Kraków-Prądnik (DA24) - 1 ex., ex coll. EM [MIZ]; Kraków-Wola Justowska (DA14), 13 VI 1880 - 1 ex., leg. SAS [ISEA]; Kraków-Zesławice (DA34), 26 IV 1994 1 ex., leg. DK [ISEA]; Modlnica (DA15), 10-24 V 1907 - 1 ex., leg. SAS [ISEA]; Przeginia Duchowna (DA04), 29-31 V 1906 - 1 ex., leg. SAS [ISEA]; Rudawa (DA05), 7 VI 1897 - 1 ex., leg. SAS [ISEA]; Zawiercie-Karlin [Karlin pow. Olkusz] (CA99), 24 IV 1952 - 1 ex., leg. MBM [MIZ]. Malopolska Upland: Busko-Zdrój, Park Zdrojowy (DA88), 6 V $2018-1$ ex. on a sticky trap on the trunk of Aesculus sp., leg. JMG; Busko- 
Zdrój (DA89), 28 VI 1956 - 1 larva, leg. et cult. BB [MIZ]; Krzyżanowice vic. Pińczów (DA68), 13 IV 1954 - 1 ex., in the trunk of a willow Salix sp., leg. BB [MIZ]; Paciorkowa Wola Stara (EB49), 1 XII 2018 - 1 ex., under the bark of a fallen Alnus glutinosa - alder carr on the bank of the River Zwolenka, leg. MM; "Polana Polichno" res. (DA69), 11 VII 1996 - 1 ex., leg. HS; Radom-Józefów (EB19), 16 VI 2005 - 1 ex., under the bark of Populus sp., leg. MM, 14 III 2017 - 1 ex., under the bark of a dead pine, dune near the River Mleczna, leg. MM; Radom-Koniówka (EB19), 29 III 1994 - 1 ex., under the bark of a rotten Populus sp., leg. MM; Radom-Las Kapturski (EB09), 28 I 1997 - 1 ex., under the bark of a dead Quercus sp., leg. MM; Radom-Młynek Janiszewski, Warszawska Street (EB19), 25 VI 1994 - 1 ex., under the bark of Salix sp. infected by Laetiporus sulphureus (BULL.) MURRILL, leg. MM; Radom-Nowa Wola Gołębiowska (EB19), 19 V 2001 - 1 ex., under the bark of Salix sp., Pacynka river valley, leg. MM; Radom-Wośniki (EB09), 22 III 1995 - 1 ex., under the bark of a dead Picea abies in a manor park, leg. MM; Sandomierz, $19 \mathrm{~V} 1956$ (EB51) - 1 ex., leg. BB, $20 \mathrm{~V} 1956$ - 1 ex., in rot at the base of the trunk, leg. BB [MIZ]; SAC "Pakosław" (EB17), 30 V 2015 - 1 ex., on a bracket fungus on Aesculum hippocastanum in a manor park, leg. MM; Włodzimierzów (DB28), 14 VIII $1958-1$ ex., leg. ZS [USMB]. Świętokrzyskie Mts.: Góry Świętokrzyskie, Łysa Góra (EB03), 3 VI 1956 - 1 ex., in a bracket fungus on a trunk of Abies alba, leg. BB [MIZ]; Świętokrzyski NP, Góra Chełmowa (EB03) ad Serwis, 25 VII 2010 - 1 ex., leg. JMG; Świętokrzyski NP, Łysica (DB93), 20 VI 2001 - 1 ex., leg. EG, ex coll. AEBG [MNHW]. Lublin Upland: Celejów (EB78), 22 V $1956-1$ ex., in the trunk of an Italian poplar Populus nigra "italica", leg. BB [MIZ]; Kazimierz Dolny (EB68), 3 V 1923 - 1 ex., ex coll. ST [MIZ], 8 IV 1939 - 1 ex., leg. AB [MIZ], 27 V 1955 - 1 ex., leg. BB [MIZ], 27 V 1955 - 1 larva, in white rot on a willow Salix sp. (adult: 29 IX 1956), leg. et cult. BB [MIZ], 5 V 1989 1 ex., leg. JS [AL]; Zaklików (EB72), 1939 - 1 ex., BN [MIZ]. Roztocze: Florianka [Florjanka Lubel.] (FB40), 10 III 1914 - 4 exx., det. ex coll. FF [MIZ]; Roztocze NP, "Bukowa Góra" strict protection area (FB30), 9 VI 1988 - 6 exx., 8 VI 1989 - 4 exx., leg. LB [RR]; Roztocze NP, "Czerkies" strict protection area (FB40), 8 VI 1988 - 3 exx., leg. LB [RR], - 1 ex., leg. DI, ex coll. AEBG [MNHW]; Roztocze NP, "Nart" strict protection area (FB40), 23 III 1986 - 1 ex., leg. DK [ISEA]; Zwierzyniec (FB40) - 2 exx., det. ex coll. FF [MIZ]; Zwierzyniec wieś (FB30), 7 VI 1955 - 1 ex., dead imago in a pupal chamber, rotting wood in the hollow of a willow Salix sp., leg. BB [MIZ]; "Debry" res. ad Krasnobród (FB40), 9 V 2018 - 2 exx., on Abies alba, leg. KSU [JMG]. Sandomierz Lowland: "Jedlina" res. ad Lubaczów (FA56), 10 VI 2013 - 1 ex., leg. JMG; Medyka, historic park, (FA31), 2014 IV $13-3$ exx., under the bark of Platanus sp., leg. TO; Metan (EB51), 29 VI 1955 - 1 ex., leg. SN [MIZ]; Niepołomice Forest ("Puszcza Niepołomicka"), Ispina (DA55), 2 VI 1991 - 1 ex., leg. RK. Western Beskid Mts.: Barania Góra (CV59), 2 VIII 1873 - 1 ex., leg. BK [ISEA]; Dziekanowice (DA32), 12 V 1898 - 1 ex., leg. SAS 
[ISEA]; Jastrzębia (DA12), 6-7 V 1897 - 1 ex., leg. SAS [ISEA]; Kobiernice (CA72), 12 VI 1906 - 1 ex., leg. SAS [ISEA]; Łazany (DA33), 20 VI 1898 - 1 ex., leg. SAS [ISEA]; Makowica (DA51), 26 VII 1939 - 1 ex., leg. AB [MIZ]; Młodów (DV77), 30 VI 1897 1 ex., leg. SAS [ISEA]; Raba Wyżna (DV29), 16 VI 1902 - 1 ex., leg. SAS [ISEA]; Roztoka Wielka (DA78), 12 IV 1899 - 1 ex., leg. SAS [ISEA]; Rytro (DV78), 2 VII 1897 2 exx., leg. SAS [ISEA]; Tęgoborze (DA70), 25 IV 1892 - 1 ex., leg. SAS [ISEA]; Tomice (CA92), 12 V 1906 - 5 exx., leg. SAS [ISEA]; Wojkowa vic. Krynica (DV96), 28 V 1985 - 1 ex., leg. DK [ISEA]; Zaborze (CA74), 7-21 V 1901 - 2 exx., leg. SAS [ISEA]; Żywiec (CA60), 22 VI 1953 - 1 ex., leg. ZSC [RP]. Eastern Beskid Mts.: Barwinek (EV57), 23 III 1991 - 1 ex., leg. DK [ISEA]; for. distr. Bircza, Trójca for. div., comp. 461 (FV19), 12 VI-14 VII 2015 - 1 ex. in the IBL-5 barrier trap, suspended from a fir snag above the Jamninka stream, leg. TN [KR]; Brzuska ad Bircza (FA01), 30 VII 2013 - 1 ex., leg. RP; Hołubla (FA11), 31 V 1884 - 1 ex., leg. BK [ISEA]; Kamienna Laworta Mt. (FV17), 19 VI 1880 - 1 ex., leg. BK [ISEA]; "Kopystanka” res. vic. (FA10), VI $2016-1$ ex., leg. TN [HS]; Krzemień Mt. (FV28) ad Krościenko, 6 VI 1881 - 1 ex., leg. BK [ISEA]; Krosno (EA50), IV-V 1947 - 2 exx., leg. SKA [ISEA], VII 1948 - 1 ex., V 1951 - 1 ex., ex coll. AEBG [MNHW]; Kuszmień Mt. (FV17), 19 VII 1884 - 1 ex., leg. BK [ISEA]; Kwaszenina vic. (FV16), VI 2011 - 1 ex., leg. RR; Magura NP: Hałbowska Pass (EV38), 10 V-10 VI $2014-1$ ex., in an IBL-5 barrier trap suspended from a fir tree trunk, leg. AM; Nieznajowa (EV28), 10 V-10 VI $2014-1$ ex., in an IBL-5 barrier trap on an ash tree Fraxinus excelsior, leg. AM; Markowa, garden, (EA94), 22 IV 1986 - 1 ex, $04 \mathrm{~V}-1$ ex, under the bark of Malus sp., leg. TO; Olszany (FA11), 24 IX 1962 - 1 ex., leg. BB [MIZ]; Pacław (FV29), for. distr. Bircza, for div. Leszczyny, comp. 35, 21 VI 2015 - 1 ex, in an IBL-5 barrier trap on Quercus robur, leg. TO; Pogórze Przemyskie, Trójca vic. (FA10), 23 VI 2011 - 1 ex., leg. RR; Posada Rybotycka (FA10), 30 V 1958 - 1 ex., leg. BB [MIZ]; Prałkowce (FA21), 25 V 1958 - 1 ex., leg. BB [MIZ]; Przemý́l vic. (FA21*), 30 exx., leg. TT [ISEA]; Przemyśl-Góra Zamkowa (FA21), 22 VI 1879 - 1 ex., leg. BK [ISEA]; Przemyśl-Ostrów (FA21), 31 V 1879 - 4 exx., leg. BK [ISEA]; Przeworsk (FA04), 24 V 1958 - 1 ex., in the trunk of a willow Salix sp., leg. BB [MIZ]; Radoszyce (EV76), 2830 V 1882 - 1 ex., leg. BK [ISEA]; Rzeszów, Zalesie (EA73), 25 V 2007 - 1 ex, forest (private), in Laetiporus sulphureus growing on Prunus avium L., 27 III $2011-2$ exx., garden, under the bark of Pyrus sp., 22 IV 2018 - 1 ex., historic park, light trap, leg. TO; Spława Mt. (FA10), 7 VI 1884 - 3 exx., 6 VII 1884 - 1 ex., leg. BK [ISEA]; Zagórz (EV98), 27 V 1970 - 1 ex., in the hollow of a jasmine Philadelphus sp., leg. BB [MIZ]; Zarszyn (EV79), 25 V 1923 - 4 exx., leg. SAS [ISEA]. Bieszczady Mts.: Cisna for. distr., Krzywe for. div., comp. 126c (EV94), 18 VI 2015 - 1 ex., obs. AM; Komańcza for. distr.: Maniów for. div., comp. 11c (EV85), 31 VII 2015 - 1 ex., obs. AM; Lutowiska for. distr.: Dwernik for. div., comp. 14b (FV14), 1 VII-23 IX 2013 - 3 exx., obs. AM; Hulskie for. 
div., comp. 73a and 81d (FV15), 15 V - 10 VI 2014 - 7 exx., obs. AM; Paniszczew for. div., comp. 81a (FV16), 15 V-10 VI 2014 - 1 ex.; comp. 116 (FV06), 29 V 2014 - 4 exx., obs. AM; Polana for. div.: comp. 114a (FV15), 20 V 2014 - 1 ex.; comp. 110d, 111c, and 111d (FV15), 15 V-10 VI 2014 - 6 exx., obs. AM; Sękowiec for. div., comp. 154A-b (FV15), 15 V-10 VI 2014 - 2 exx., leg. AM; Ustrzyki Górne (FV24), 6 VI 1958 - 1 larva (imago: 28 VII 1959), leg. et cult. BB [MIZ].

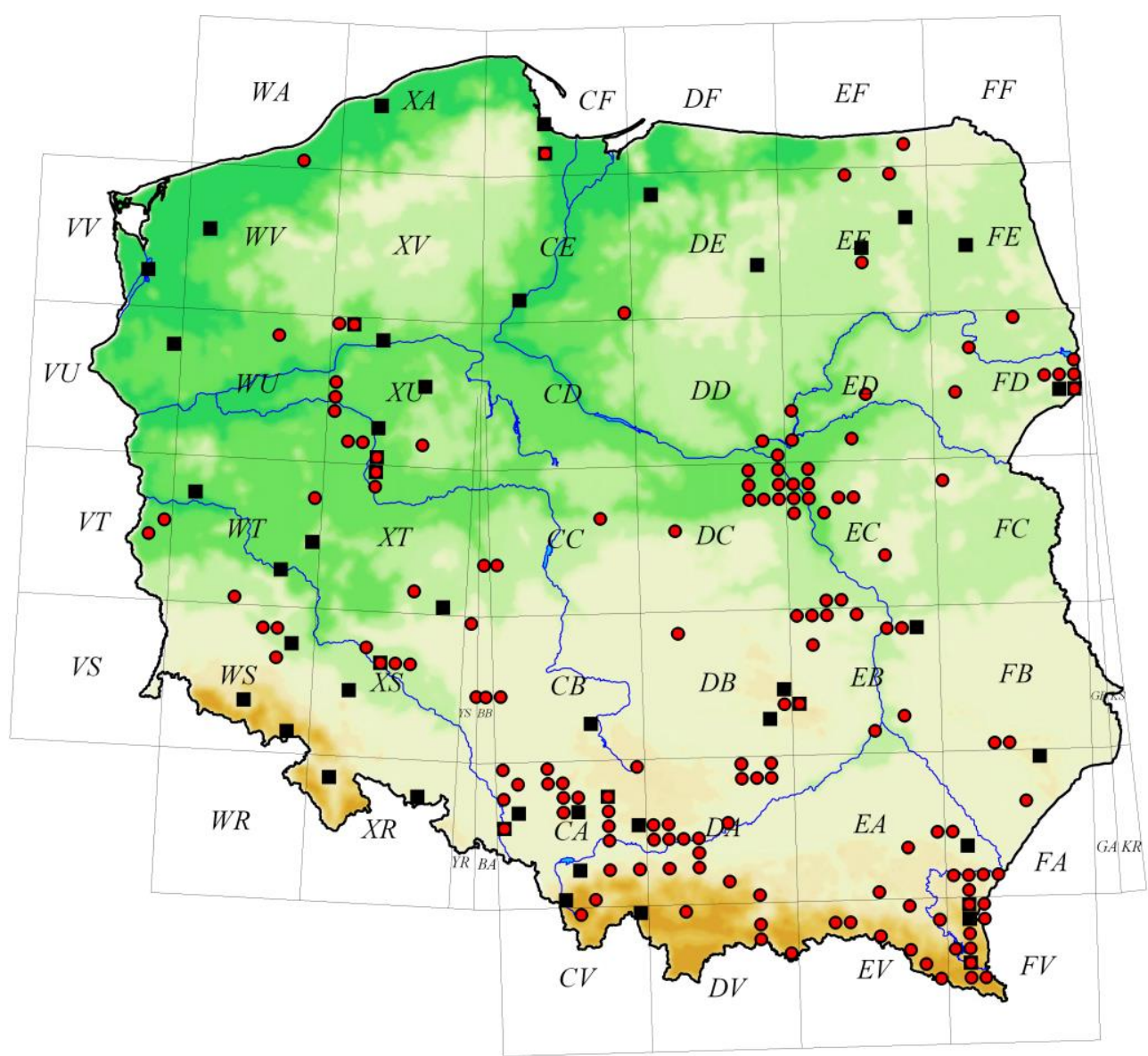

Fig. 9. Grynocharis oblonga (published records - black squares, records reported in the present paper - red circles) - distribution in Poland. 
Distribution. Widely distributed in Europe. Common, with records from all over Poland. Recently recorded in the "Bieszczady" Natura 2000 site (OLBRYCHT et al. 2015), Gryżyński LP (RUTA et al. 2016) and Zdrojowy Park in Nałęczów (MıŁKOwSKI 2017). Newly recorded in Podlasie (Fig. 9).

Biology. Larvae and adults are fungivorous and develop in the rotting wood of trees with soft wood, mostly broadleaved (willow, poplar, occasionally oak, beech, alder and hornbeam) and coniferous (fir) trees (BURAKOWSKI et al. 1986, KOLIBÁČ et al. 2005, this study). According to the list in Table 1, this is the most ubiquitous species of the families under discussion here in the Polish fauna. It has been recorded on 20 genera of trees, preferring oaks (23\% of records), willows (18\%) and poplars (17\%). Adults are collected both under the bark and on polypores throughout the year; they are active from mid-April until mid-July, and pupate in August.

Lophocateres pusillus (KLUG, 1833)

Material examined. Baltic Coast: Gdynia (CF44), 11 VII $1934-2$ exx. leg. AB [ISEA].

Distribution. A cosmopolitan beetle, native to tropical and subtropical areas, introduced in other regions of the world. A few cases of introduction to Gdynia (Fig. 2) in the 1960s were noted by BURAKOWSKI et al. (1986). A specimen collected as long ago as 1934 indicates that it had been introduced much earlier, in the first years of operation of the port in Gdynia.

Biology. Larvae and adults inhabit stored products, like rice, maize and other grains.

\section{Family: Peltidae \\ Peltis ferruginea (LINNAEUS, 1758)}

Material examined. Pomeranian Lake District: Szczecin [Stettin] (VV71) - 1 ex., ex coll. PH [MIZ]. Masurian Lake District: Augustów Port, 30 III 1955 - 1 ex., in dry rot on a lime tree Tilia sp., by Lake Rospuda (FE27/FE37), leg. BB [MIZ]; "Mazury" res. (EE79), 8 IX 2018 - 1 ex., under the bark of a dead Picea abies, leg. MM; Biebrza NP (Middle basin), Czerwone Bagno ad Grzędy (FE24), 3 IX 2013 - 2 exx. under the bark of a fallen spruce Picea abies, leg. PJ; Augustów Forest, for. distr. Płaska, "Mały Borek" res. (FE57), 9 V 2013 - 1 ex., under the bark of a pine Pinus sp. snag, $45 \mathrm{~cm}$ in diameter, leg. JMG; Augustów Forest, "Starożyn" res. (FE57), 13 VI 1978 - 1 ex., leg. MW; Pisz Forest, Pogobie Średnie vic., comp. 41 (EE53), 18 V 2015 - 1 ex., 19 V-10 VI 2015 - 2 exx., in IBL-2bis barrier traps, leg. JMG; Pisz Forest, Pogobie Średnie vic., "Szast" reference forest, comp. 75 (EE53), 6-27 V 2013 - 3 exx., 18 V 2015 - 6 exx., 19 V-10 VI 2015 - 
1 ex., in IBL-2bis barrier traps, leg. JMG; Pisz Forest, Pogobie Średnie vic., comp. 90 (EE53), 6-27 V 2013 - 1 ex., in an IBL-2bis barrier trap, leg. JMG; Pisz Forest, Pogobie Średnie vic., "Szast" reference forest, comp. 117 (EE53), 19 V-14 VI 2005 - 1 ex., 18 V 2015 - 3 exx., 19 V-10 VI 2015 - 4 exx., in IBL-2bis barrier traps, leg. JMG; Pisz Forest ad Ruciane Nida, Zgon vic., "Królewska Sosna” res. (EE24), 7 IV 2014 - 1 ex., leg. JMG; Pisz Forest, ad Pisz, Snopki vic., comp. 239 (EE44), pine forest, 23 IV-21 V 2013 - 2 exx., in an IBL-2bis barrier trap, leg. JMG; Pisz Forest, ad Pisz, Snopki vic., comp. 241 (EE44), pine forest, 6-27 V 2013 - 1 ex., 19 V-10 VI 2015 - 1 ex., in IBL-2bis barrier traps, leg. JMG; Pisz Forest, ad Pisz, Snopki vic., comp. 248 (EE44), pine forest, 23 IV-21 V 2013 1 ex., in an IBL-2bis barrier trap, leg. JMG; Pozezdrze ad Węgorzewo (EF60), 27 IV 2018 - 1 ex., leg. KSU. Wielkopolska-Kujawy Lowland: Nabłoto ad Brody (VT83), 5 X 2011 - 1 ex., leg. SK; "Uroczysko Węglińskie" res. vic. Węgliny (VT74/84), 25 VI 2011 2 exx., under the bark of Pinus sp., leg. SK. Mazovian Lowland: Otwock [Jabłoń] (EC17), 1 VII 1901 - 1 ex., leg. WM [USMB]; Otwock-Świder [Świder] (EC17), 4 VII 1903 2 exx., leg. WM [USMB]; Kozienice, "Załamek” forest res. (EC20), 23 XII $2018-1$ ex., under the bark of a rotten fir Abies alba; Warszawa, 9 VIII 1906 - 1 ex., ex coll. ST [MIZ]; Warszawa-Bielany [Bielany] (DC99), 2 V 1890 - 1 ex., 4 V 1894 - 1 ex., 14 VI 1895 1 ex., leg. WM [USMB]; Warszawa-Bielany [Bielany ad Warszawa] (DC99), 13 II 1955 1 ex., in a crevice of dry rot on a fallen Alnus glutinosa, leg. BB [MIZ]; Warszawa-Bielany [Ruda Podleśna ad Warszawa Bielany], (DC99), 24 VII 1930 - 1 ex., leg. BB [MIZ]; Warszawa-Łazienki [Łazienki] (EC08), 15 V 1910 - 1 ex., 28 IV 1918, ex coll. ST [MIZ]; Warszawa-Morysin [Morysinek ad Warszawa] (EC07), 11 IV 1955 - 1 ex., in red-brown dry rot on a large, living willow Salix sp., leg. BB [MIZ]; Warszawa-Natolin [Natolin] (EC07), 24 V 1930 - 1 ex., ex coll. ST [MIZ]; Warszawa-Ogród Saski [Saski Ogród] (EC08), 2 V 1891 - 1 ex., leg. WM [USMB]; Warszawa, Zoological Garden (EC09), 25 VIII 1940 - 1 ex., under the bark of a willow Salix sp., ex coll. ST [MIZ]; Warszawa Wawer [Wawer] (EC18), 16 VI 1900 - 2 exx., leg. WM [USMB]; Zegrze (ED01), 7 VI 1935 - 1 ex., ex coll. ST [MIZ]. Podlasie: "Krasne" res. ad Supraśl (FD59), 7 III 2018 1 ex., leg. KSU; Białystok (FD48*), 26 III 1951 - 3 exx., leg. BB [MIZ]; BiałystokJaroszówka (FD49), 30 VI 2018 - 3 exx., under the bark of a dead, fallen Pinus sylvestris, leg. JTD; Knyszyn Forest, "Krzemienne Góry” res. (FD69), 7 IV 2010 - 2 exx., leg. JMG \& KSU, 21-27 IV 2011 - 1 ex., leg. AK, det. et coll. JMG; Knyszyn Forest, "Krzemienne Góry" res., comp. 167 (FD69), 26 V 2011 - 1 ex., under the bark of a spruce Picea abies, leg. JMG; Knyszyn Forest, Rybniki vic., "Krzemianka” res. (FE40), 20 VIII 2011 - 1 ex., leg. KT, det. et coll. JMG; Knyszyn Forest, ad Supraśl (FD59), 20 VII 1992 - 1 ex., leg. AL; Włodawa (FC71), 24 VII 1983 - 1 ex., leg. JPA [ISEA]; “Załamanek” res. (EC20), 23 XII 2018 - 1 ex., under the bark of a rotten fir Abies alba, leg. MM. Bialowieża Primeval Forest: Białowieża NP, ad Gruszki, comp. 105B (FD95), burned site, 9 V 2016 - 3 exx., 
10-23 V 2016 - 2 exx., 16 VIII 2016 - 1 ex., in a Netocia trap, 9-21 V 2017 - 1 ex., in a black, baited funnel trap, 9 V 2016 - 1 ex., in a Moericke trap, 10-23 V 2016 - 1 ex., 4 VII 2016 - 1 ex., in a Netocia trap, leg. JMG; Białowieża NP, comp. 191A (FD95), 25 IX 2009 - 1 ex., leg. KSU; Białowieża NP [former for. distr. Browsk], comp. 192 (FD95), 11 VI 1965 - 2 exx., leg. BB [MIZ]; Białowieża NP, by the River Hwoźna [former for. distr. Browsk] (FD95), 20 III 1952 - 1 ex., leg. BB [MIZ]; Białowieża NP, comp. 223 (FD95), 28 V 1954 - 2 exx., leg. BB [MIZ]; Białowieża NP, comp. 224 (FD95), 3 VI 1954 - 1 ex., 5 VI 1954 - 4 exx., under the bark of a spruce Picea abies, leg. BB; Białowieża NP, comp. 253D (FD84), Narewka river valley, 7-13 V 1997 - 2 exx., 14-19 V 1997 - 2 exx., 27 V-2 VI 1998 - 1 ex., 19-25 V 1999 - 4 exx., 3-9 V 2000 - 1 ex., 17-23 V 2000 - 1 ex., in unbaited IBL-2bis barrier traps, leg. JMG; Białowieża NP, comp. 255 (FD95), 21 VII 1995 - 2 exx., leg. AL; Białowieża NP, comp. 282B (FD85), Narewka river valley, 7-13 V 1997 - 2 exx., 14-19 V 1997 - 4 exx., 27 V-2 VI 1998 - 1 ex., in unbaited IBL-2bis barrier traps, leg. JMG; Białowieża NP, comp. 288C (FD94), mixed coniferous forest, 1997 2 exx., leg. KSU; Białowieża NP, comp. 288C/318A (FD94), mixed coniferous forest, 26 VI 1989 - 1 ex., 15 V 1990 - 2 exx., 17 V 1991 - 1 ex., 31 V 1991 - 1 ex., 14 VI 1991 - 1 ex., 17 VI 1991 - 1 ex., 12 V 1992 - 1 ex., 26 V 1992 - 2 exx., 21 VI 1994 - 1 ex., 9 V 1995 - 1 ex., 23 V 1995 - 1 ex., 6 VI 1995 - 1 ex., 12 V 1999 - 1 ex., 10 V 2000 1 ex., 7 V 2002 - 4 exx., 14 V 2003 - 1 ex., 8 VI 2004 - 1 ex., 19 V 2005 - 1 ex., 4 V 2006 - 1 ex., 18 V 2006 - 4 exx., 1 VI 2006 - 1 ex., 26 IV 2007 - 4 exx., 10 V 2007 - 5 exx., 1 V 2008 - 2 exx., 15 V 2008 - 8 exx., 29 V 2008 - 1 ex., 30 IV 2009 - 5 exx., 12 V 2010 - 3 exx., 27 IV 2011 - 1 ex., 11 V 2011 - 8 exx., 25 V 2011 - 2 exx., 30 IV 2013 - 2 exx., 14 V 2013 - 11 exx., 29 IV 2014 - 5 exx., 13 V 2014 - 5 exx., 22 VII 2014 - 2 exx., 28 IV 2015 - 1 ex., in IBL-2bis barrier traps, mostly unbaited, in rare cases - turpentine baited, the first specimen was hand collected, leg. JMG; Białowieża NP, comp. 288C/318A (FD94), mixed coniferous forest, 7 V 1993 - 2 exx., 20 V 1998 - 1 ex., 11 V 2004 - 1 ex., 25 V 2004 - 1 ex., 12 V 2010 - 1 ex., 27 IV 2011 - 1 ex., 11 V 2011 - 1 ex., 9 V 2012 1 ex., 14 V 2013 - 1 ex., 13 V 2014 - 1 ex., in Moericke yellow pan traps installed at a height of $1 \mathrm{~m}$, leg. JMG; Białowieża NP, comp. 314 (FD94), 19 IV 1967 - 2 larvae (imagines: 16 VI 1967), leg. BB [MIZ]; Białowieża NP, comp. 317C (FD94), mesic mixed deciduous forest, 27 V 1988 - 1 ex., leg. JMG; Białowieża NP, comp. 318 (FD94), 26 VII 1996 - 1 ex., mesic mixed coniferous forest, in rotting wood, leg. AL; Białowieża NP, comp. 318B (FD94), mixed coniferous forest Calamagrostio-Piceetum, 11 V 2004 - 2 exx., in an IBL-2bis barrier trap, leg. JMG; Białowieża NP, comp. 318B (FD94), mixed coniferous forest, 12 IX 2007, remains of an imago in the wood of a fallen, rotten spruce Picea abies, leg. KSU; Białowieża NP, comp. 340 (FD94), 1 V 1991 - 1 ex., leg. RK; Białowieża NP, comp. 341/342 (FD94), 2 VI 1954 - 2 exx., leg. BB [MIZ]; Białowieża NP, comp. 368E (FD94), Narewka river valley, 19-25 V 1999 - 4 exx., 3-9 V 2000 - 1 ex., 19- 
25 VII 2001 - 2 exx., in IBL-2bis barrier traps, leg. JMG; Białowieża NP, comp. 369 (FD94), 17 IV 1967 - 1 ex., in the rotting wood of a spruce Picea abies, leg. BB [MIZ]; Białowieża NP, comp. 370D (FD94), oak-hornbeam forest, 12 VIII 1985 - 1 ex., leg. JMG; Białowieża NP, comp. 373 (FD94), 13 VI 1994 - 4 exx., alder forest, under a rotting log of Betula sp., leg. AL; Białowieża NP, comp. 374 (FD94), oak-hornbeam forest, 12 IX 2002 1 ex., rotting wood, leg. AL; Białowieża NP, comp. 374C (FD94), 2 X 2007 - 2 exx., under the bark of a fallen spruce Picea abies ca. $40 \mathrm{~cm}$ in diameter, leg. JMG; Białowieża NP, comp. 398G (FD94), 26 IX 1998 - 2 exx., leg. RD [USMB]; Białowieża NP, comp. 398 (FD94), 13 XI 1959 - 4 exx., under the bark of a dead spruce Picea abies, leg. BB [MIZ]; Białowieża NP, comp. 398/399 (FD94), 25-26 IX 1998 - 1 ex., leg. RK; Białowieża NP, comp. 399C (FD94), 2 V 1991 - 1 ex., leg. DK [ISEA]; Białowieża NP, comp. 399C (FD94), oak-hornbeam forest, 7 V 1993 - 1 ex., 24 V 1994 - 2 exx., leg. JMG; Białowieża NP, comp. 399 (FD94), oak-hornbeam forest, 9 V 1959 - 1 larva (imago: 6 VI 1959), leg. BB, 9 V 1959 - 2 larvae (imagines: 10 VII 1959), leg. BB [MIZ], 4 V 1961 - 1 ex., leg. SA [MIZ]; Białowieża NP, comp. 399 (FD94), 25 VII 1982 - 1 ex., 16 VI 1983 - 1 ex., 10 VI 1983 - 2 exx., leg. MW; Białowieża NP (FD94), 22 X 1949 - 1 ex., leg. JMA [MIZ], 25 V 1957 - 1 ex., coniferous forest, leg. BP, PT [MIZ], 30 V 2000 - 1 ex., leg. HS; Białowieża NP (FD95), 26 VI 1991 - 4 exx., leg. TM [HS]; Białowieża NP/for. distr. Białowieża, Droga Browska (FD94), comp. 374D/403B, 7-13 V 1997 - 2 exx., 14-19 V 1997 - 2 exx., 20-27 V 1997 - 2 exx., 5-11 V 1999 - 1 ex., 19-25 VII 2001 - 1 ex., in IBL-2bis barrier traps, leg. JMG; Białowieża NP/for. distr. Białowieża, Droga Browska (FD94), comp. 375B/375D, 7-13 V 1997 - 6 exx., 14-19 V 1997 - 3 exx., 5-11 V 1999 - 2 exx., 2-8 VI 1999 - 1 ex., 19-25 VII $2001-3$ exx., in IBL-2bis barrier traps, leg. JMG; Białowieża NP/for. distr. Białowieża, Droga Browska (FD94), 9 V 1998 - 2 exx., in a pheromone trap, leg. MM, 18 VII $2000-3$ exx., under the bark of a dying spruce Picea abies, leg. RR; Białowieża, Palace Park (FD94), 8 II 1982 - 1 ex., under the bark of Pinus strobus L., leg. JMG; Białowieża (FD94), 29 IX 1950 - 2 exx., 30 IX 1950 - 1 ex., 5 X 1950 - 1 ex., 19 III 1952 - 3 exx., 20 III 1952 - 11 exx., leg. BB [MIZ], 17 V 1957 - 3 exx., leg. BP [MIZ]; Białowieża (FD94), 11-14 VIII 1976 - 3 exx. leg. MB [ISEA]; Białowieża (FD94), 1 V 1989 - 1 ex., under the bark of Quercus sp., leg. RK; Białowieża vic. (FD94), 28 VIII 1998 - 1 ex., rotten trunk of Betula sp., leg. SK; Białowieża vic., “Żebra Żubra” walking trail (FD84), 7 IV 1995 - 2 exx., rotten log, leg. SK; Czerlonka (FD84), 6 VI 1988 - 1 ex., leg. HS; Grudki [Gródek] (FD93), 4 VIII 1982 - 3 exx., leg. MW; ad Hajnówka, comp. 356 (FD74), 29 VII 1955 - 2 exx., leg. BB [MIZ]; for. distr. Białowieża, comp. 224 (FD95), in a spruce, 16 V 1955 - 3 exx., leg. BB [MIZ]; for. distr. Białowieża, comp. 424C (FD84), 14 IX 1997 - 1 ex., leg. RD [USMB]; for. distr. Białowieża, ad Pogorzelce, comp. 424C (FD84), oak-hornbeam forest, $25 \mathrm{~V} 2015$ - 1 ex., leg. JMG; for. distr. Białowieża, comp. 450-451 (FD84), 24 IV 1990 - 5 exx., leg. JG; for. distr. Białowieża, comp. 471 (FD84), 19 
XI 1959 - larvae (imagines: 13 VI 1961), leg. BB [MIZ]; for. distr. Białowieża, comp. 493D (FD83), mixed coniferous forest, pole, $26 \mathrm{~V} 1988$ - 1 ex., in a turpentine baited IBL2 bis barrier trap, leg. JMG; for. distr. Białowieża, comp. 494C (FD83), 24 V 2011 - 1 ex., in an IBL-2bis barrier trap, leg. JMG; for. distr. Białowieża, ad Grudki (FD93), 8 VII 1988 - 3 exx., leg. JMG; for. distr. Białowieża, comp. 521B/D (FD83), mesic mixed coniferous forest, old-growth, $26 \mathrm{~V} 1988-1$ ex., in an IBL-2bis barrier trap, leg. JMG; for. distr. Białowieża, comp. 525 (FD83), 26 VI 1990 - 1 ex., leg. JG; for. distr. Białowieża, for. div. Grudki, comp. 526 (FD93), 12 V 2001 - 1 ex., under the bark of Picea abies, leg. MM; for. distr. Browsk, comp. 15B (FD96), 28 III 2014 - 1 ex., under the bark of a dead Picea abies, leg. RK; for. distr. Browsk, ad Narewka (FD85), 3 VI 1984 - 1 ex., leg. JMG; for. distr. Browsk, comp. 78A (FD85), 2 V 1996 - 1 ex., leg. JŁ [USMB]; for. distr. Hajnówka, comp. 519D (FD83), 26 VI 2005 - 1 ex., under the bark of Populus tremula, leg. RK; for. distr. Hajnówka, ad Topiło, comp. 629C (FD73), pine-spruce coniferous forest, 25 IX 2008 - 1 ex., in a fallen, rotten trunk of Picea abies, leg. JMG; for. distr. Hajnówka, comp. 629D (FD73), 7 VII 2008 - 1 ex., under the bark of Pinus sylvestris, leg. RK; Pogorzelce (FD84), 16 VI 1991 - 3 exx., leg. LB [RR]; "Starzyna" res. (FD72), 1 V 2002 - 2 exx., obs. RR; Stara Białowieża (FD85), 20 VI 2017 - 1 ex., on a spruce log, leg. JTD; comp. 491A (FD94), 18 V 2017 - 8 exx., on a spruce Picea abies overgrown with fungi (at night), leg. JTD; Białowieża Forest, 13 VII 1949 - 1 ex., leg. RB [MIZ]; Białowieża Forest (FD85), 19 VII 1995 - 5 exx., 20 VII 1995 - 6 exx., leg. RD [USMB]. Lower Silesia: Wrocław [Breslau] (XS46), $20 \mathrm{~V} 1929-1$ ex., 30 VI (year unknown) - 1 ex., leg. GP [MNHW]; Wrocław-Świniary (XS37), 24 IV 1992 - 1 ex., leg. LB [RR], 5 V 2016 - 1 ex., obs. RR. Upper Silesia: Boruszowice, "Dęby Boruszowickie" res. (CA49), 19 VI 1993 - 1 ex., leg. JG; Brynek (CA39), 17 VIII 2002 - 1 ex., 13 V 2008 - 1 ex., 4 V 2009 - 3 exx., 25 V 2014 - 1 ex., 14 VII 2015 - 1 ex., leg. HS; Bukowo vic. Kluczbork (BB94), 26 V 1995 - 1 ex., leg. RK; Brzezinka (CA27), 19 X 1923 - 2 exx., leg. KK [USMB], - 1 ex., ex coll. WK [MNHW]; Chełmek (CA75), 2 V 1882 - 1 ex., leg. SAS [ISEA], 28 IV 1932 - 1 ex., leg. KB [USMB]; Dąbrowa Górnicza (CA77), 10 V 1936 - 1 ex., leg. KS [USMB]; "Lężczok" res. (CA05), 18 V 2016 - 1 ex., leg. JM [HS]; Murcki (CA66), 6 VI 1928 - 2 exx., 21 V 1930 - 2 exx., leg. HN [USMB], 13 VI $1934-8$ exx., leg. FK [USMB]; for. distr. Kluczbork, for. div. Tuły, comp. 96 (BB94), 19 IX 1999 - 1 ex., under the bark of Picea abies, leg. RK; Rudno ad Rudziniec (CA18), 31 VIII 1992 - 2 exx., from rotting wood of Picea abies, leg. RK; Rudziniec (CA18), 15 V 1993 - 1 ex., leg. HS; Tworóg (CB30), 11 VIII 2002 - 1 ex., 27 VI 2005 - 1 ex., leg. HS; Zaborze (CA47), 7-14 V 1901 - 6 exx., 1530 VII 1903 - 1 ex., leg. SAS [ISEA]; Zawadzkie (CB20), 15 VIII 1981 - 1 ex., leg. HS; Zawiercie (CA89), 1912 (301) - 1 ex. [MIZ]. Kraków-Wieluń Upland: Czatkowice (DA05), 18 IX 1904 - 1 ex., leg. SAS [ISEA]; Głogoczów (DA23), 22 V 1897 - 5 exx., leg. SAS [ISEA]; Kraków (DA14) - 2 exx., ex coll. EM [MIZ], 26 IV 1918 - 1 ex., leg. SP 
[ISEA]; Kraków-Dębniki (DA14), $24 \mathrm{~V}$, year unknown (end of $19^{\text {th }}$ century) -4 exx., leg. MR [ISEA]; Kraków, Botanical Garden (DA24), 20 V 1936 - 2 exx., leg. SP [ISEA]; Kraków-Płaszów (DA24), 2 VI 1912 - 1 ex., leg. SP [ISEA]; Kraków-Zwierzyniec (DA14), 1 V 1915 - 1 ex., leg. SAS [ISEA]; Ojców (DA16), 26 IV 1952 - 1 ex., leg. RB [MIZ]. Małopolska Upland: SAC "Lasy Suchedniowskie", Świnia Góra vic. (DB75), 14 X 2015 - 1 ex., under the bark of Abies alba overgrown with sporocarps of Fomitopsis pinicola (Sw.) P. KARST., leg. JTD; “Świnia Góra” res. near Skarżysko-Kamienna (DB85), 19 IX 2010 - 3 exx., leg. JMG; Tunel near Miechów (DA28), VI 1985 - 1 ex., leg. JKM [ISEA]. Lublin Upland: Kazimierz Dolny [Kazimierz] (EB68), 3 V 1923 - 1 ex., ex coll. ST [MIZ]; Lublin-Majdanek [Majdanek, Lubel.] (FB17) - 2 exx., ex coll. FF [MIZ]; Puławy (EB69), IV 1907 - 1 ex., ex coll. ST [MIZ]. Świętokrzyskie Mts.: CisowskoOrłowiński LP, "Zamczysko" res. (DB92), 20 V 1982 - 1 ex., leg. LB [RR]; "Chełmowa Góra” res., 3 km N of Nowa Słupia, (EB03), 18 IX 2000 - 1 ex., leg. RR, 19 IX 2010 2 exx., leg. RK; SAC "Ostoja Wierzejska”, Kielce vic. (DB74), 23 IX 2014 - 4 exx., under the bark of a fir tree Abies alba, leg. AM; Góry Świętokrzyskie, 15-29 V $1957-2$ exx., leg. JPO [MIZ]; Góry Świętokrzyskie, Łysa Góra (EB03), 2 VI 1956 - 1 ex., under the bark of Abies alba, leg. BB, 15 IX 1968 - 1 ex., under the bark of Abies alba, leg. BB, 15 IX 1968 - 2 exx., under the bark of A. alba, leg. BB, 15 IX $1968-1$ ex., rotten wood near a fir Abies alba, leg. BB [MIZ]; Góry Świętokrzyskie, Św. Katarzyna (DB93), 7 VII 1956 1 ex., leg. SN [MIZ], Świętokrzyskie Mts., Świętokrzyski NP, for. div. Podgórze, Uroczysko Przylaski (DB94), 26 X 1955 - 4 exx., under the bark of an oak Quercus sp., leg. BB [MIZ]; Świętokrzyskie Mts., Świętokrzyski NP, comp. C-1 (DB93), 8 VIII 1962 2 exx., leg. MBM [MIZ]; Huta Szklana vic. (EB03), 10 V $2002-3$ exx., leg. RR; Św. Katarzyna (DB93), 13 VII 2014 - 6 exx., leg. JG; Świętokrzyski NP, Łysica (DB93), 20 VI 2001 - 1 ex., leg. AG, ex coll. AEBG [MNHW], 15 VIII 2007 - 1 ex., leg. MW; Świętokrzyski NP, Św. Krzyż (EB03), 21 V 1982 - 1 ex., leg. LB [RR], 6 IX 1994 - 1 ex., leg. HS; Świętokrzyski NP, Bartoszowiny vic. (EB03), 15 X 2018 - 1 ex., on the sporocarp of Fomitopsis pinicola on a dead Abies alba, obs. JTD. Roztocze: "Bukowa Góra" res. ad Zwierzyniec (FB30), 5-9 VI 1989 - 1 ex., leg. MW, 2 VII 1985 - 1 ex., leg. DK [ISEA]; "Debry" res. ad Krasnobród (FB40), 9 V 2018 - 1 ex., on Abies alba, leg. KSU; Grele (FB40), 14 VIII 1911 - 1 ex., ex coll. ST [MIZ]; Roztocze NP, "Nart" strict protection area [Nart] (FB40) - 4 exx., ex coll. FF [MIZ], 15 VII 1910 - 2 exx., ex coll. ST [MIZ]; Roztocze NP, "Czerkies" strict protection area (FB40), 8 VI $1988-3$ exx., leg. DI, ex coll. AEBG [MNHW]; Roztocze NP, "Nart" strict protection area (FB40), 13 IV 1985 - 1 ex., $15 \mathrm{~V} 1987$ - 1 ex., leg. DK [ISEA], 30 VI 1988 - 1 ex., under the bark of a dead Abies alba, leg. JMG. Sandomierz Lowland: Brusno (FA66), 13 VI $1880-2$ exx., leg. BK [ISEA]. Eastern Sudeten Mts.: Góry Bialskie, "Puszcza Śnieżnej Białki” res. (XR46), 31 VII $2002-3$ exx., under the bark of a fallen Picea abies, leg. AL; Śnieżnik massif, 
Kamienica valley (XR37), 6 VI 1989 - 1 ex., leg. AM [ISEA]; Śnieżnik massif, N of "Śnieżnik Kłodzki" res. (XR36), 17 IX 2014 - 1 ex., under the bark of a dead Picea abies, leg. RK. Western Beskid Mts.: Babia Góra NP, Czatożańska Primeval Forest (CV99), 23 VI 1998 - 1 ex., in a fir tree Abies alba, leg. AM; Babia Góra, Markowe Szczawiny (CV99), 17 IV 1966 - 1 ex., under the bark of a dead Picea abies, leg. BB [MIZ]; Babia Góra NP, under Sokolica Mt. (CV99), 1 X 2011 - 1 ex., under the bark of a dead Picea abies, leg. MM; Barania Góra (CV59), 2 VIII 1873, VII 1876 - 5 exx., leg. BK [ISEA]; Silesian Beskids, Szyndzielnia massif (CA51), 23 V 1994 - 1 ex., under the bark of Picea abies, leg. MM; Silesian Beskids, Równica mountain range, Ustroń Jaszowiec (CA40), 2014 IV 28 - 1 ex., leg RK; Czarna Wisełka (CV59), 9 VIII 1956 - 1 ex., 21 VII 1964 1 larva (dead imago: 21 VII 1964), 2 V 1968 - 2 exx., leg. BB [MIZ]; Dolina Czarnej Wisełki (CV59), 1 V 2014 - 4 exx., leg. JG; Kłaj (DA53), 1904 - 22 exx. leg. MR [ISEA]; Mosorny Groń (CV99), 2 V 2018 - 1 ex., on a trunk of Fagus sylvatica, leg. JTD; Młodów (DV77), 14 VII 1899 - 44 exx., leg. SAS [ISEA]; Osieczany (DA22), 25 VI 1899 - 1 ex., leg. SAS [ISEA]; Paleśnica (DA82), 1987 - 1 ex., leg. JKM [ISEA]; Radziejowa Mt. (DV77), 15 VII 1899 - 2 exx., leg. SAS [ISEA]; Roztoka Mała (DV78), 25 V $1892-1$ ex., leg. SAS [ISEA]; Roztoka Wielka (DV78) - 5 VII $1892-1$ ex., 14 VIII $1892-3$ exx., 9 VI 1896 - 5 exx., 22 VII 1899 - 2 exx., 26 V 1900 - 1 ex., 15 VII 1901 - 1 ex., 2 VI 1905 1 ex., leg. SAS [ISEA]; Rytro (DV78), 2 VII 1897 - 3 exx., leg. SAS [ISEA], 1 VIII $1929-$ 2 exx., 10 VIII 1929 - 1 ex., ex coll. ST [MIZ]; Rytro, Roztoka (DV78), 14 VII 1949 1 ex., leg. MBM [MIZ]; Sieraków (DA32), 20 VI 1908 - 1 ex., leg. SAS [ISEA]; Skrzyczne Mt. (CA50), VIII 1884 - 2 exx., leg. BK [ISEA]; Tymbark (DA50), 3 V 1905 1 ex., leg. SAS [ISEA]; Wierchomla (DV87), 29 VI 1897 - 1 ex., leg. SAS [ISEA]; WisłaGłębce (CV49), 2 VII 1964 - 2 exx., on a piece of spruce Picea abies wood covered with mould, leg. BB [MIZ]; Zawoja-Czatoża (CV99), 7 VIII 1936 - 1 ex., 20 VIII 1937 - 2 exx., 17 VIII 1939 - 1 ex., leg. SP [ISEA]; Zawoja-Policzne (CV99), 19 VII 1938 - 3 exx., leg. SP [ISEA]. Nowy Targ Basin: Zakopane (DV26), 1872 - 1 ex., leg. BK [ISEA]. Eastern Beskid Mts.: Bircza (FA00), Panieński Czub Mt., 4-22 V 1879 - 6 exx., leg. BK [ISEA]; Brzuska ad Bircza (FA01), 30 VII 2013 - 1 ex., leg. RP; for. distr. Bircza: Arłamów for. div., comp. 137b (FV19), 3 V-2 VI 2016 - 1 ex. in an IBL-2 barrier trap, leg. TN [HS]; Borysławka for. div., Kanasin Mt., southern slopes, comp. 115a (FV19), 27 V-16 VI 2015 - 1 ex. in an IBL-2 barrier trap, suspended from a fir snag in Carpathian beech forest, leg. TN [KR]; Jamna for. div., the south-eastern slope of Mt. Jamna, comp. 141a (FV19), 26 V16 VI 2015 - 1 ex., in an IBL-5 barrier trap suspended from a fir snag ca. $110 \mathrm{~cm}$ in diameter, beech forest with old firs (Boros schneideri (PANZER, 1796) and Lacon lepidopterus (PANZ.) were observed in the same area), leg. AM \& TN [KR]; Jureczkowa for.div., Karaszyn Forest, comp. 194a (FV18), 1 V 2011 - 1 ex. under the bark of a fir tree Abies alba, obs. AM \& R. Michalski; Łodzinka for. div., comp. 157a (FA10), 2 V-1 VI 
2016 - 1 ex. in an IBL-2 barrier trap, leg. TN [HS]; Sierakośce for. div., comp. 8a and 22a (FA20), 5 V-3 VI 2016 - 6 exx. in an IBL-2 barrier trap, leg. TN [HS]; Trójca for. div., comp. 461 (FV19), 12 VI-14 VII 2015 - 1 ex. in an IBL-5 barrier trap, suspended from a fir snag above the Jamninka stream, leg. TN [KR]; Trzcianiec for. div.: comp. 223b (FV09), 2 V-1 VI 2016 - 1 ex. in an IBL-2 barrier trap, leg. TN [HS]; comp. 229a (FV09), 3 V-2 VI 2016 - 1 ex. in an IBL-2 barrier trap, leg. TN [HS]; comp. 230a (FV09), 3 V-2 VI 2016 - 2 exx. in an IBL-2 barrier trap, leg. TN [HS]; Turnica for. div., ad Suchy Obycz Mt., comp. 160b (FV19), 2 V 2011 - 1 ex., under the bark of a fir tree Abies alba, obs. AM; for. distr. Brzozów, Bykowce for. div., comp. 210c (EV98), 4 V-5 VI 2016 - 1 ex. in an IBL-2 barrier trap, leg. MB [HS]; Gorlice (EA10), 30 IV 1916 - 1 ex., leg. SAS [ISEA]; Jarosław (FA24), 11 V 1889 - 1 ex., leg. SAS [ISEA]; "Kalwaria Pacławska" res. (FV29), 10 V 2018 - 2 exx., under the bark of Abies alba, leg. TO \& KSU; Krosno (EA50), VI 1951 1 ex., ex coll. AEBG [MNHW], 13 VIII 1950 - 1 ex., leg. RB [MIZ]; Krzemień Mt. (FV28) ad Krościenko, 6 VI 1881 - 8 exx., leg. BK [ISEA]; Kwaszenina (FV19), 10 IX 2011 3 exx., leg. HS; Las Karaszyn (FV28), for. distr. Bircza, for. div. Jureczkowa, comp. 184, 27 IX 2011 - 3 exx., under the bark of Abies alba, leg. TO; Magura NP, Baranie (EV47), 27 V 1995 - 1 ex., leg. WKU; Magura NP, Hałbowska Pass (EV38), 10 V-10 VI 2014 1 ex., in an IBL-5 barrier trap suspended from a fir tree Abies alba trunk, leg. AM; Pacław (FV29), forest (private), 5 VI 2016 - 1 ex, in an IBL-5 barrier trap on $Q$. robur, leg. TO; Piotruś ad Tylawa (EV58), for. distr. Dukla, for. div. Piotruś, comp. 32, 10 IX 2017 2 exx., under the bark of Abies alba, leg TO; Pogórze Przemyskie, Trójca vic. (FA10), 23 VI 2011 - 1 ex., leg. RR; "Przełom Jasiołki" res. (EV57), 27 V 2016 - 1 ex., in an IBL-2 barrier trap on Abies alba, leg. TO; Przemyśl vic. (FA21*), 22 exx., leg. TT [ISEA]; Przemyśl-Ostrów (FA21), 25 V 1879 - 4 exx., leg. BK [ISEA]; Radiów Wierch ad Bandrów Narodowy (FV27), for. distr. Ustrzyki Dolne, for. div. Brzegi, comp. 107, 29 IX 2012 - 2 exx., under the bark of Abies alba, leg. TO \& AM; Radoszyce (EV76), for. distr. Komańcza, for. div. Radoszyce, comp. 150, 26 VII $2012-2$ exx., under the bark of Abies alba, leg. TO; "Reberce" res. vic. (FA10), 1 V-1 VI 2016 - 2 exx. in an IBL-2 barrier trap, leg. TN [HS]; Spława Mt. (FA10), 7 VI 1884 - 7 exx., leg. BK [ISEA]; Trójca (FA10), 2 V-1 VI 2016 - 1 ex. in an IBL-2 barrier trap, leg. TN [HS]; "Turnica" res. (FV19), 17 XI 2012 - 2 exx., under the bark of Abies alba, leg. TO, 1 V-1 VI $2016-4$ exx. in an IBL-2 barrier trap, leg. TN [HS]. Bieszczady Mts.: Cisna for. distr.: Buk for. div., comp. 83 (FV05), 10 VI 2015 - 3 exx., obs. AM; Habkowce for. div. (EV95), 18 VI 2015 - 1 ex., leg. AM; Strzebowiska for. div., comp. 128b (FV04), 3 VII 2015 - 1 ex., under the bark of a fir snag Abies alba of $80 \mathrm{~cm}$ in diameter, obs. AM; Lutowiska for. distr.: Hulskie for. div., comp. 80k (FV15), 15 V-10 VI 2014 - 5 exx., obs. AM; comp. 93a (FV05), 15 V-10 VI 2014 - 3 exx., obs. AM; Paniszczew for. div., comp. 118g (FV06), 24 V $2014-3$ exx., under the bark and in the roots of a very old fir Abies alba with a diameter of more than 180 
cm, obs. AM; Polanki for. div., comp. 110b (FV15), 15-31 V 2014 - 1 ex., leg. AM; Rosochate for. div., comp. 93c (FV25), 1 VII-23 IX 2013 - 2 exx., obs. AM; Stuposiany for. distr., Sokoliki for. div., comp. 266a (FV33), 17 V 2014 - 2 exx., obs. AM; Bieszczady ad Komańcza (EV76), 1 VI 1970 - 2 exx., Abies alba - Pinus sylvestris forest, leg. BB [MIZ]; for. distr. Tarnawa, for. div. Sokoliki, (FV33), 7 V 1968 - 2 exx., under the bark of a spruce Picea abies, leg. BB [MIZ]; Otryt, the slope of hill 889 (FV25), 6 VI 1970 - 1 ex., leg. BB [MIZ]; Smolnik on the River San (FV25), 17 VI 1958 - 1 ex., 14 VI 1958 - 1 ex., under the bark of a fallen lime tree Tilia sp., on a meadow, leg. BB [MIZ]. Pieniny Mts.: Kosarzyska vic. (DV57), 15 V 2017 - 6 exx., on Fomitopsis pinicola growing on a fir Abies alba, leg. PCH [AM]; Pieniny NP: Harczygrunt (DV57), 9 IV 2017 - 1 ex. on Oligoporus caesius (SCHRAD.: FR.) GILBERTSON \& RYVARDEN on spruce in a fir-spruce forest, leg. PCH [PNPM]; Pieniny glade vic. (DV57), 11 V 2017 - 1 ex., on Antrodia serialis (FR.) DONK on spruce in old beech and fir trees, leg. PCH [AM]; Pieniny, Potok Hulina valley (DV67), 25 VII 1939 - 1 ex., ex coll. ST [MIZ]; Pieniny, Droga Pienińska (DV57), 17 VIII 1939 - 1 ex., under the bark of a beech Fagus sylvatica, ex coll. ST [MIZ]; Pieniny, Golica (DV57), 20 VIII 1939 - 1 ex., under the bark of a spruce Picea abies, ex coll. ST [MIZ]; Pieniny, Krasy (DV57), 14 VIII 1928 - 1 ex., under the bark of a spruce Piceaabies, ex coll. ST [MIZ]; Pieniny, Potok Pieniński (DV57) - 4 exx., leg. RB [MIZ]; Pieniny, Pustelnia Św. Kingi (DV57), 1 VI 1929 - 1 ex., ex coll. ST [MIZ]; Pieniny, Stolarzówka (DV57), 20 VII 1939 - 1 ex., under the bark of Abies alba, ex coll. ST [MIZ]; Potok Pieniński valley (DV57), 31 VII 1939 - 1 ex., ex coll. ST [MIZ]; Szczawnica (DV67), 17 VI 1942 - 1 ex., leg. JR [USMB]; Wielka valley (DV57), 10 VIII 2017 - 7 exx., on Antrodia sinuosa (FR.) P. KARST. growing on a spruce at the edge of a beech-fir forest, leg. PCH [AM]. Tatra Mts.: Ciemniak Mt (DV25), 1-3 VI 2003 - 1 ex., leg. EB [SK]; Kościeliska valley (DV15), 25 VII 1949 - 1 ex., leg. AR [MIZ]; Strążyska valley (DV25), 29 VII 1879 - 1 ex., leg. BK [ISEA]; Zakopane vic., Ścieżka nad Reglami (DV25), 3 V 2009 - over 10 exx., under the bark of a fallen spruce Picea abies, leg. JTD.

Distribution. A widely distributed, Holarctic species. Known from the whole of Poland, though rarely encountered. Most records are from the south and east of the country. More common in well-preserved forests rich in deadwood overgrown with fungi. Recently recorded by OLBRYCHT et al. (2015) in the "Bieszczady" Natura 2000 site co-occurring with Rhysodes sulcatus (FABRICIUS, 1787) and in the Roztocze region (PAPIS, MOKRZYCKI 2015). New for the Małopolska Upland and the Nowy Targ Basin (Fig. 10).

Biology. Larvae develop in the rotting wood of various trees, and occasionally in building timber (BURAKOWSKI et al. 1986, KOLIBÁČ et al. 2005). The data summarised in the present paper show that it prefers coniferous trees, like spruce (39\% of records) and fir $(35 \%)$. Adults can be seen throughout the year in places where beetles feed and conceal 


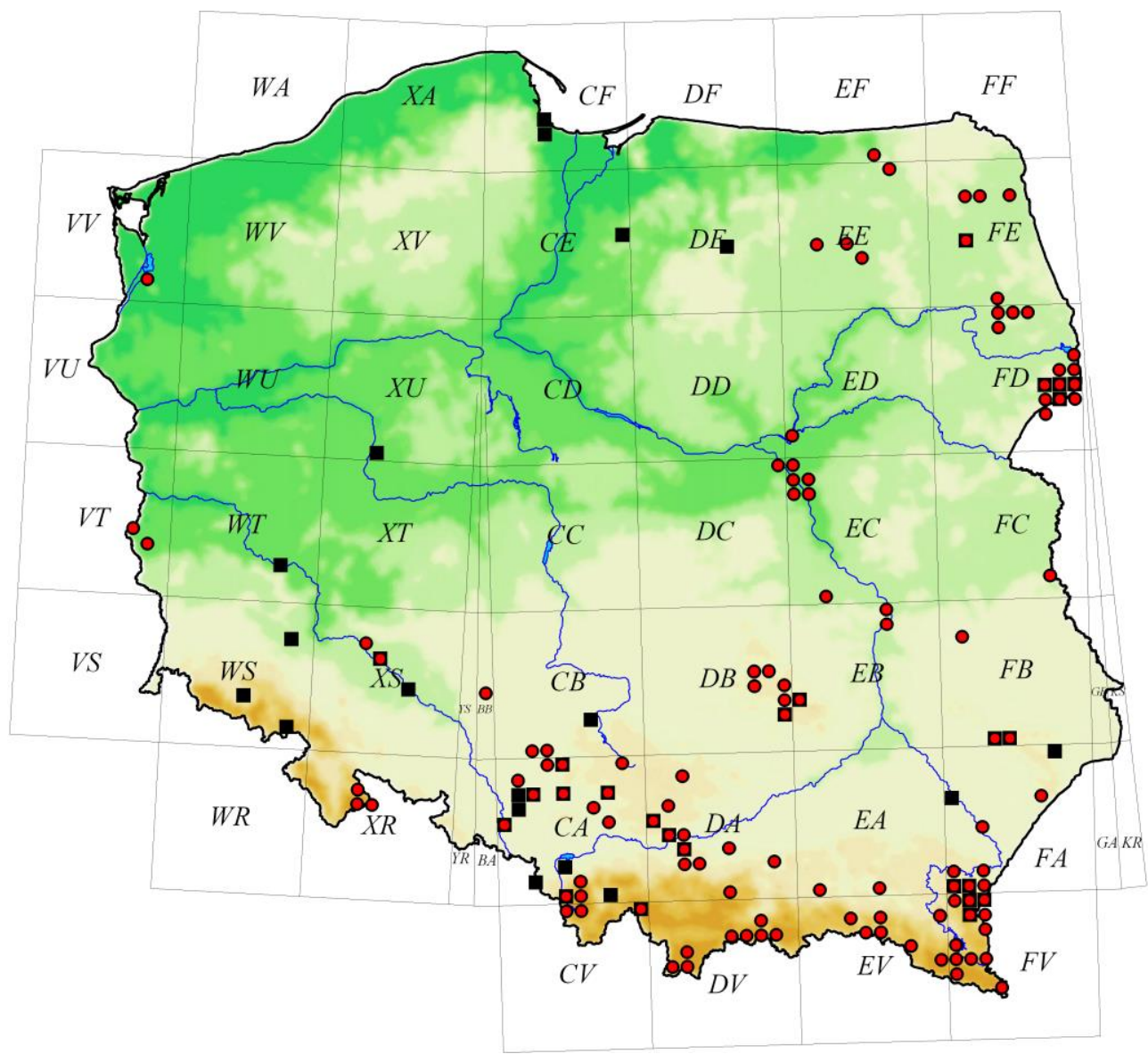

Fig. 10. Peltis ferruginea (published records - black squares, records reported in the present paper - red circles) - distribution in Poland.

themselves - under bark, in decaying wood, in the crevices of trunks, hollows, etc. The beetles can be observed from April until mid-October, with their activity peaking between late April and late July.

Peltis grossa (LinNaeus, 1758)

Material examined. Masurian Lake District: for. div. Boczki, Gołdap (EF91), 29 III 1955 - 11 exx., in a broken birch, dry, white-yellow rot, leg. BB [MIZ]; Pisz Forest, "Szast" reference forest ad Pogobie Średnie (EE53), 5 V 2011 - 1 ex., under the bark of a broken Betula pendula $25 \mathrm{~cm}$ in diameter, leg. JMG, pine forest, 6-27 V $2013-1$ ex., 18 
VI-10 VII 2013 - 1 ex., in an IBL-2bis barrier trap, leg. JMG; Pisz Forest, Snopki vic. ad Pisz (EE44), pine forest, 5 V 2011 - 2 exx., 6-27 V 2013 - 1 ex., 18 V-10 VI 2015 2 exx., in IBL-2bis barrier traps, leg. JMG. Mazovian Lowland: Otwock-Świder [Świder] (EC17), 4 VII 1903 - 2 exx., leg. WM [USMB]; Warszawa-Bielany [Bielany] (DC99), 23 V 1900 - 1 ex., leg. WM [USMB]. Podlasie: Knyszyn Forest, "Jesionowe Góry" res. (FE51), 27 IV 2010 - 1 ex., in a fallen Betula pendula trunk, leg. JMG; Knyszyn Forest, "Las Cieliczański" res. vic. Białystok, comp. 7 (FD59), 14 IV 2010, remains of an imago in a fallen, rotting birch Betula sp., leg. JMG. Białowieża Primeval Forest: Białowieża NP, ad Gruszki, comp. 105B (FD95), burned site, 9 V - 1 ex., 23 V - 1 ex., 6 VI 2016 - 2 exx., in Netocia traps installed at $1 \mathrm{~m}$ height on living pines, 22 V-5 VI 2017 - 1 ex., in a black, baited funnel trap, leg. JMG; Białowieża NP, comp. 111B (FD95), 5 V 2018 - 1 ex., under the bark of a dead Picea abies, leg. MM; Białowieża NP, comp. 163C/194A (FD95) 1 ex., under the bark of an old, dead Alnus glutinosa $40 \mathrm{~cm}$ in diameter, leg. KSU; Białowieża NP, comp. 192 (FD95), 16 V 1965 - 1 ex., leg. BB [MIZ]; Białowieża NP, comp. 224 (FD95), 3 VI 1954 - 1 ex., 5 VI 1954 - 3 VI 1955 - 2 exx., leg. BB [MIZ]; Białowieża NP, comp. 253D (FD84), Narewka river valley, 20-27 V 1997 - 1 ex., in an IBL-2bis barrier trap, leg. JMG; Białowieża NP, comp. 288C/318A (FD94), mixed coniferous forest Calamagrostio-Piceetum, 19 VI 1997 - 1 ex., 3 VI 1998 - 1 ex., 10 V 2000 - 2 exx., 24 V 2000 - 2 exx., 21 VI 2000 - 1 ex., 29 V 2001 - 1 ex., 12 VI 2001 1 ex., 24 V 2002 - 4 exx., 4 VI 2002 - 1 ex., 14 V 2003 - 1 ex., 28 V 2003 - 2 exx., 8 VI 2004 - 4 exx., 22 VI 2004 - 1 ex., 2 VI 2005 - 1 ex., 18 V 2006 - 1 ex., 15 VI 2006 1 ex., 29 V 2008 - 1 ex., 12 VI 2008 - 1 ex., 26 VI 2008 - 1 ex., 30 IV 2009 - 1 ex., 14 V 2009 - 1 ex., 29 V 2009 - 1 ex., 11 V 2011 - 1 ex., 23 V 2012 - 1 ex., 14 V 2013 - 2 exx., 27 V 2014 - 1 ex., in IBL-2bis barrier traps , 29 VI 2006 - 1 ex., 24 V 2007 - 1 ex., in Moericke traps, 7 VI 2007 - 2 exx., in Netocia type traps, leg. JMG; Białowieża NP, comp. 314 (FD94), 19 XI 1967 - 1 ex., in the trunk of Alnus glutinosa, leg. BB [MIZ]; Białowieża NP, comp. 314 (FD94), 2 V 1993 - 1 ex., leg. TM [HS]; Białowieża NP, comp. 316 (FD94), 4 V 1964 - 1 ex., in the trunk of a spruce, leg. BB [MIZ]; Białowieża NP, comp. 318B (FD94), mixed coniferous forest, 12 IX $2007-3$ exx. and feeding traces in a fallen, badly decayed (with fruiting bodies of Fomitopsis pinicola and Fomes fomentarius (L.)) Betula pendula $40 \mathrm{~cm}$ in diameter, remains of an imago in a snag of a rotten (white and brown rot, fruiting body of Fomes fomentarius) Betula pendula $30 \mathrm{~cm}$ in diameter, remains of an imago in a snag of a rotten (brown rot) Betula pendula $35 \mathrm{~cm}$ in diameter, leg. JMG; Białowieża NP, comp. 340 (FD94), 17 XI $1967-2$ exx., in the trunk of a fallen lime tree Tilia sp., leg. BB [MIZ]; Białowieża NP, comp. 341/342 (FD94), 2 VI 1954 - 1 ex., leg. BB [MIZ]; Białowieża NP, comp. 341/371 (FD94), $30 \mathrm{~V} 1955$ - 3 exx., rotten wood of a lime tree Tilia sp., 7 VI 1955 - 1 ex., dead adult, leg. BB [MIZ]; Białowieża NP, comp. 342 (FD94), 10 VI 1965 - 1 ex., leg. BB [MIZ]; Białowieża NP, comp. 368E (FD94), 
Narewka river valley, 17-23 V $2000-1$ ex., in an IBL-2bis barrier trap, leg. JMG; Białowieża NP, comp. 369 (FD94), 19 VII 1998 - 1 ex., leg. MW; Białowieża NP, comp. 370D (FD94), oak-hornbeam forest, 12 VIII 1985 - 2 exx., leg. JMG; Białowieża NP, comp. 373 (FD94), 13 VI 1994 - 1 ex., in rotten wood, leg. AL; Białowieża NP, comp. 398 (FD94), 18 IV 1967 - 3 exx., trunk of a lime tree, leg. BB [MIZ]; Białowieża NP, comp. 399 (FD94) - 1 ex., oak-hornbeam forest [MIZ]; Białowieża NP, comp. 400 (FD94), 25 VII 1982 - 1 ex., leg. MW; Białowieża NP, 4 V 1961 - 1 ex., leg. SA [MIZ]; Białowieża (FD94), 2 IV 1951-19 III 1952 - 5 exx., leg. BB [MIZ]; Białowieża (FD94), 25 VII 1982 3 exx., leg. LB, ex coll. AEBG [MNHW]; Białowieża NP/for. distr. Białowieża, Droga Browska, comp. 375B/375D (FD94), 14-19 V 1997 - 1 ex., 20-27 V 1997 - 1 ex., in an IBL-2bis barrier trap, leg. JMG; Białowieża NP/for. distr. Białowieża, Droga Browska (FD94), 9 V 1998 - 1 ex., under the bark of a spruce Picea abies, leg. MM, 30 IV 2002 2 exx., leg. RR; Białowieża NP/for. distr. Białowieża, Droga Browska (FD84), 30 V 2014 over 10 exx., on the trunk of a spruce Picea abies overgrown with fungi (at night), leg. JTD; Braszcza - bridge over the river (FD95), 20 V 2017 - 1 ex., in flight, leg. JTD; for. distr. Białowieża, comp. 523/547 (FD83), Podcerkwa wood depot, 4 VI 1954 - 1 ex., leg. BB [MIZ]; for. distr. Browsk, comp. 129D (FD95), 18 VII 1981 - 1 ex., leg. JŁ [USMB]; for. distr. Browsk [currently Białowieża NP], comp. 158A (FD95), 21 VI 1984 - 1 ex., leg. JŁ [USMB]; Nowe Masiewo vic., comp. 66D (FD95), 14 XI 2012 - 2 exx., under the bark of Populus tremula, leg. JŁ [AL]; Białowieża Forest (FD94), 1 V 1991 - 1 ex., leg. RK; Białowieża Forest (FD84), 26 VI 1991 - 1 ex., leg. TM [HS]; Białowieża Forest (FD85), 15 VII 1995 - 3 exx., leg. RD [USMB]; Białowieża Forest, 28 V 1981 - 1 ex., leg. AJ [HS]; Topiło vic., comp. 598 (FD73), 4 IV 2001 - 1 ex., in rotten wood, leg. AL. Upper Silesia: Katowice Panewniki (CA56), 26 X 1920 - 1 ex., leg. HN [USMB]. Malopolska Upland: "Świnia Góra" res. ad Skarżysko-Kamienna (DB75), 19 IX 2010, remains of an imago and feeding traces on a fallen, rotting Abies alba $60 \mathrm{~cm}$ in diameter, leg. JMG, 29 VII $2015-$ 1 ex., leg. MW [PJ]. Świętokrzyskie Mts.: Huta Szklana (EB03), 10 V $2002-1$ ex., leg. MW; Łysa Góra (EB03), 3 VI 1956 - 2 larvae on Abies alba (imagines: 10 XI 1956), leg. BB [MIZ]; SAC "Ostoja Wierzejska”, Kielce vic. (DB74), 22 IX 2014 - 2 exx., under the bark of a fir snag Abies alba, together with Cucujus cinnaberinus (SCOP.), leg. AM; Św. Katarzyna (DB93), 18 V 1957 - 1 ex., under the bark of Abies alba, leg. JPO [MIZ]; Świętokrzyski NP, Łysica (DB93), 20 VI 2001 - 1 ex., leg. AG, ex coll. AEBG [MNHW]; Świętokrzyski NP, Łysica massif (DB93), 7 VII 1995 - 3 exx., on a bracket fungus on a dead Abies alba, leg. MM; Świętokrzyski NP, "Święty Krzyż” res. (EB03), 15 VI 1979 1 ex., leg. MW, 14 VIII 1994 - 1 ex., reared from a pupa collected on the trunk of a rotting Abies alba collected on 12 VIII 1994, leg. et cult. MM; Świętokrzyski NP, Św. Katarzyna (DB93), 16 VII $2009-1$ ex., under the bark of a dead Abies alba, leg. MM \& LBU; Świętokrzyski NP, comp. C-1 (DB93), 8 VIII 1962 - 3 exx., leg. MBM [MIZ]; 
Świętokrzyski NP, Bartoszowiny vic. (EB03), 15 X 2018 - 1 ex., on fruiting Fomitopsis pinicola on a dead Abies alba, obs. JTD. Roztocze: "Bukowa Góra" strict protection area ad Zwierzyniec (FB30), 8 VI 1955 - 1 ex., under the bark of Abies alba, leg. BB [MIZ], 2 VII 1985 - 1 ex., leg. DK [ISEA], 5-9 VI 1989 - 4 exx., 29 VI 1990 - 2 exx., leg. MW; Roztocze NP, "Czerkies" strict protection area (FB40), 23 IX 1987 - 4 exx., 15 VI 1990 2 exx., leg. LB, 8 VI 1988 - 4 exx., leg. DI, ex coll. AEBG [MNHW], 10 VI 1989 - 1 ex., leg. MW; Roztocze NP, "Nart" strict protection area (FB40), 30 VI 198 - 1 ex., 15 V 1987 - 2 exx., leg. DK [ISEA], 30 VI 1988 - less than 10 exx., under the bark of dead Abies alba trees, leg. JMG; "Debry" res. ad Krasnobród (FB40), 9 V 2018 - 1 ex., on Abies alba, leg. KSU; Zwierzyniec (FB41), 3 VI 1987 - 2 exx., leg. LBU [HS], [JG]. Sandomierz Lowland: Ispina (DA55) ad Niepołomice, VI $1984-1$ ex., leg. KP [ISEA]. Western Beskid Mts.: Barania Góra (CV59), 2 VIII $1873-8$ exx., leg. BK [ISEA]; Chabówka (DV29), 12 IX 1898 - 1 ex., leg. SAS [ISEA]; Czantoria Mt. (CA40), VII $1876-8$ exx., leg. BK [ISEA]; Młodów (DV77), 15 VII 1898 - 2 exx., 12 V 1899 - 4 exx., 14 VII 1899 2 exx. leg. SAS [ISEA]; Polanka Wielka (CA73), 12 IX 1901 - 1 ex., leg. SAS [ISEA]; Ptaszkowa (DV99), 17 VI 1892 - 1 ex., leg. SAS [ISEA]; Roztoka Wielka (DV78), 26 VI 1892 - 3 exx., 7-17 VII 1892 - 4 exx., 14 VIII 1892 - 6 exx., 16 V 1896 - 1 ex., 9-21 VI 1896 - 11 exx., 14 VII 1897 - 1 ex., 10-14 VII 1898 - 13 exx., 15-22 VII 1899 - 2 exx., 7-11 VIII 1899 - 4 exx., 24 V 1900 - 2 exx., 15 VII 1901 - 4 exx., 5 V 1918 - 1 ex., leg. SAS [ISEA]; Rytro (DV78), 2 VII 1897 - 5 exx., 19 VII 1898 - 1 ex., 19-20 VI 1919 2 exx. leg. SAS [ISEA]; Skrzyczne Mt. (CA50), VIII $1884-7$ exx., leg. BK [ISEA]; distr. Sucha Beskidzka (CA91), 5 VII 1955 - 3 exx. [MIZ]; Zawoja (CA90), 14 VII 1948 5 exx., leg. JPO [MIZ]; Zawoja-Czatoża (CV99), 7 VIII 1936 - 2 exx., 20 VII 1937 - 1 ex., 5-15 VII 1938 - 7 exx., 17 VIII 1939 - 5 exx. leg. SP [ISEA]; Żegiestów (DV87), 15 VIII 1892 - 2 exx., leg. SAS [ISEA]. Eastern Beskid Mts.: Arłamów (FV19), for. distr. Bircza, for. div. Turnica, comp. 178, 7 VII $2012-1$ ex, under the bark of Abies alba, leg. TO; Bircza (FA00), Panieński Czub Mt., 4-22 V 1879 - 15 exx., leg. BK [ISEA]; Barwinek (EV57), 6 VII 1987 - 1 ex., leg. DK [ISEA]; Beskid Niski, Barwinek ad Dukla (EV57), 23 VII 1988 - 2 exx., in rot on Abies alba, 8 VII 1992 - 1 ex., leg. RK; for. distr. Bircza, Trójca for. div., comp. 461 (FV19), 12 VI-14 VII 2015 - 1 ex., in an IBL-5 barrier trap, suspended from a fir above the Jamninka stream, leg. TN [KR]; Buczacz (FA02), $21 \mathrm{~V}-24$ VI 2016 - 1 ex., in an IBL-2 barrier trap, leg. AM [HS]; Grąziowa (FV09), for. distr. Bircza, for. div. Krzywe, comp. 93, 14 VI 2012 - 3 exx., under the bark of Abies alba, leg. TO \& AM; Jamna Dolna (FV19), 3 VI 2012 - 3 exx., old cemetery, under the bark of Tilia cordata, leg. TO \& AM; "Kalwaria Pacławska" res. (FV 29), 10 V 2018 - 11 exx, under the bark of Abies alba, leg. TO \& KSU; for. distr. Krasiczyn, Krzeczkowa for. div., comp. 230h (FA11), VI 2012 - 1 ex., leg. AM; Kupna for. div., comp. 213a (FA11), V 2012 2 exx., leg. AM; Olszany for. div., comp. 139A-b (FA11), V 2012 - 4 exx., leg. AM; 
Krzemień Mt. (FV28) ad Krościenko, 6 VI 1881 - 1 ex., leg. BK [ISEA]; Kuszmień Mt. (FV17), 19 VII 1884 - 6 exx., leg. BK [ISEA]; Las Karaszyn (FV28), for. distr. Bircza, for. div. Jureczkowa, comp. 184, 10 IX 2011 - 1 ex, 27 IX 2011 - 2 exx., under the bark of Abies alba, leg. TO; Lipowica ad Krosno (EV58), 4 VI 1971 - 1 ex., ex coll. AEBG [MNHW]; Magura NP: Feszówka Mt. (EV38), 24 VI 2014 - 2 exx., under the bark of a fir snag Abies alba $50 \mathrm{~cm}$ in diameter, leg. AM; Folusz vic. (EV29), 30 VIII $2014-1$ ex., a dead specimen under the bark of an old fir Abies alba $80 \mathrm{~cm}$ in diameter, leg. AM; Hałbowska Pass (EV38), 10 V-10 VIII 2014 - 4 exx., in an IBL-5 barrier trap suspended from a fir tree trunk, leg. AM; Huta Krempska vic. (EV38), 17 VII 2014 - 1 ex., under the bark of a fir snag Abies alba $45 \mathrm{~cm}$ in diameter, leg. AM; Kornuty Mt. (EV29), 19 VIII 2014 - 1 ex., under the bark of a fir snag Abies alba ca. $70 \mathrm{~cm}$ in diameter, leg. AM; Krempna vic. (EV38), 10 V 2014 - 2 exx., under the bark of a fir snag Abies alba $50 \mathrm{~cm}$ in diameter, leg. AM; Magura Wątkowska Mt. (EV29), 8 VIII 2014 - 1 ex., under the bark of a fir snag Abies alba $40 \mathrm{~cm}$ in diameter, leg. AM; Pogórze Przemyskie, Trójca vic. (FA10), 23 VI 2011 - 1 ex., leg. RR; Przemyśl vic. (FA21*), 17 exx., leg. TT [ISEA]; Puławy Górne (EV68), 28 I 2014 - 1 ex., for. distr. Rymanów, for. div. Pastwiska, comp. 54, under the bark of Pinus sylvestris, leg. TO; Spława Mt. (FA10), 7 VI 1884 - 13 exx., leg. BK [ISEA]; Stebnik (FV27), 5 VI 1881 - 2 exx., leg. BK [ISEA]; Suchania Mt. (EV48), 7 VIII $2014-2$ exx., under the bark of a fir snag Abies alba $45 \mathrm{~cm}$ in diameter, leg. AM; Suchy Obycz (EV19) ad Arłamów, 31 VIII 2017 - 2 exx., under the bark of Abies alba, leg. TO. Bieszczady Mts.: Bereżki (FV24), 25 VII 1967 - 1 ex., leg. JP [ISEA]; Bieszczadzki NP.: Caryńskie (FV14), 14 IX 2014 - 1 ex, old cemetery, on the bark of Abies alba, leg. TO; Bystre ad Baligród: south-western slope of Michałowa Mt. (EV96), 4 I 2014 - 1 ex., leg. AM; Cisna for. distr.: Buk for. div., comp. 97 (FV05), 16 V 2015 - 3 exx., obs. AM; comp. 73b (FV15), 8 VI 2014 - 2 exx., leg. AM; Czarne ad Baligród (EV96), 5-10 VII 1955 1 ex., leg. STO [MIZ]; Dzidowa Mt., Partyja Mt. (EV96), 5-6 I 2014 - 4 exx., obs. AM; Dźwiniacz for. div., comp. 60b (FV24/FV34), 19 V 2014 - 12 exx., under the bark of old, dying birches Betula sp. in a moist forest, obs. AM; Habkowce for. div., a shelter on the slope of Hon Mt. (EV95), 28 V 2015 - 1 ex., obs. AM; Hoszów [Choszów] (EV17), 29 VI 1953 - 2 exx., leg. BB [MIZ]; Hulskie for. div. comp. 80k (FV15), 10 V-15 VI $2014-$ 1 ex., obs. AM; comp. 73b (FV15), 8 VI 2014 - 2 exx., leg. AM; Jabłonki ad Baligród, Łysy Wierch Mt. (EV95), 6 I 2014 - 2 exx., obs. AM; Jawornik for. div., comp. 71b (FV15), 9 VI $2014-3$ exx., under the bark of a fir tree Abies alba over $80 \mathrm{~cm}$ in diameter, obs. AM; Komańcza for. distr., Maniów for. div., comp. 33A-a (EV85), 9 VIII 2015 1 ex., obs. AM; Krzywe for. div., comp. 126 (EV94), 18 VI 2015 - 1 ex., obs. AM; Liszna for. div., comp. 148 (EV95), VI-VIII 2015 - 1 ex., leg. AM; comp. 166 (EV94), VI 2015 1 ex., obs. AM; Lutowiska for. distr. Dwernik for. div., comp. 9c and 11i (FV15), 9-15 VII 


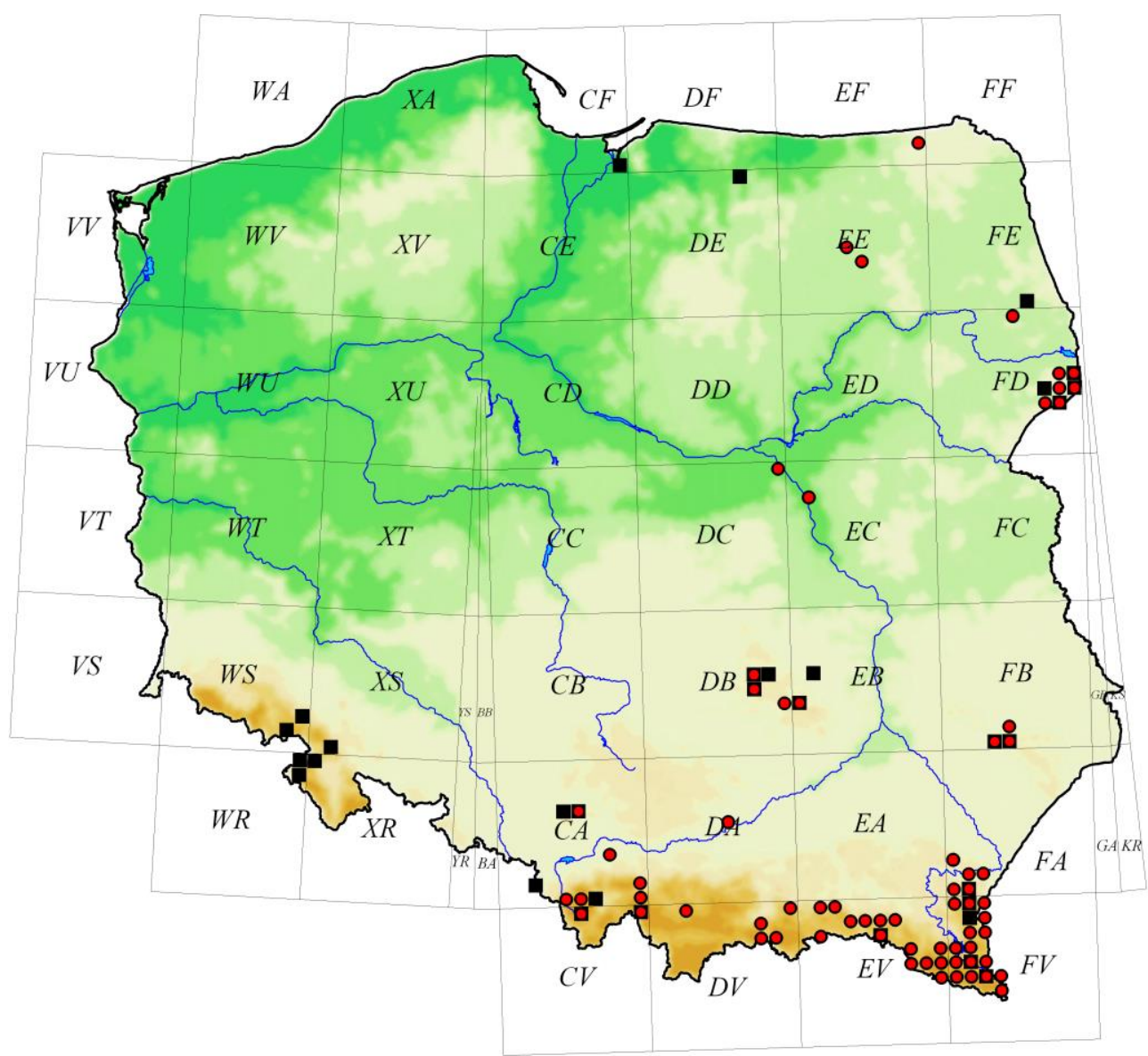

Fig. 11. Peltis grossa (published records - black squares, records reported in the present paper - red circles) - distribution in Poland.

2013 - 3 exx., obs. AM; Łubne-Żenowate (EV95), 11 VII 1971 - 1 ex., leg. ZS [USMB]; Muczne for. div., comp. 40a and 56c (FV24), 15 V-10 VI 2014 - 4 exx., obs. AM; Okrąglik for. div., comp. 123 (FV04), VI $2015-6$ exx., under the bark of old firs Abies alba, obs. AM; Paniszczew for. distr. comp. 85a (FV06), 26 V 2014 - 2 exx., obs. AM; comp. 118g (FV06), $24 \mathrm{~V} 2014-3$ exx. under the bark and in the rot of a very old fir Abies alba with a diameter of more than $180 \mathrm{~cm}$, leg. AM; Polana for. div. comp. 80B-a (FV16), 10 V-15 VI 2014 - 2 exx., obs. AM; comp. 108b (FV15), 31 V-15 VI 2014 - 2 exx., obs. AM; comp. 114a (FV15), 10 V-15 VI 2014 - 1 ex., leg. AM; Radoszyce for. div., comp. 


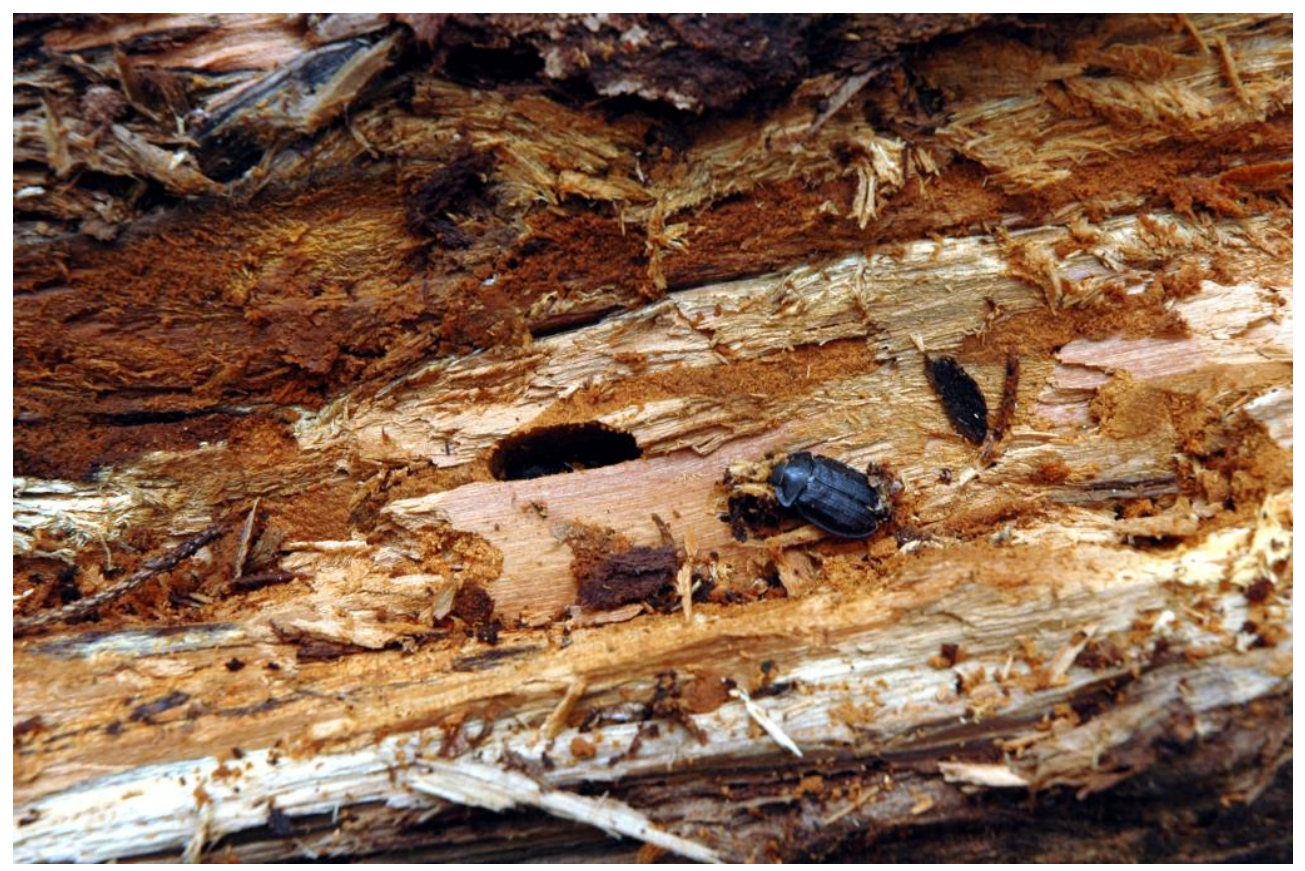

Fig. 12. Peltis grossa - an adult and larval galleries in a birch log, Knyszyn Forest; phot. J.M. GUTOWSKI.

157d (EV76), 7 VI 2015 - 1 ex., leg. AM; comp. 222a (EV75), 9 VI 2015 - 1 ex. in a timber yard, obs. AM; Rosochate for. div., comp. 88a and 123A-b (FV25), 2-5 VII 2013 - 2 exx., obs. AM; comp. 96b, 96c, 97b (FV15), 7 VII-23 IX 2013 - 7 exx., obs. AM; Sękowiec for. div., comp. 144d and 154A-b (FV15), 1-15 VI 2014 4 exx., leg. AM; Smolnik for. div., comp. 45a (EV85), 14 VIII 2015 - 1 ex., obs. AM; Sokoliki for. div., comp. 266c and f (FV33), 17 V 2014 - 3 exx., obs. AM; Stuposiany (FV25), village, 17 VII 2013 - 1 ex, on firewood, leg TO; Stare Sioło for. div. comp. 97 (FV04), 3 VII 2015 - 1 ex., obs. AM; Strzebowiska for. div., comp. 128 (FV04), 3 VII 2015 - 1 ex., leg. AM; Stuposiany for. distr., Czereszenka for. div., comp. 2f, 10c, and 15a (FV25), 3-9 VII 2013 - 5 exx., obs. AM; Suche Rzeki vic., Jaworniki Mt. (FV15), 4-8 VI 2016 - 1 ex., in an IBL-2 barrier trap, leg. AM \& R. GIL; Tworylczyk for. div., comp. 93a (FV05), 1-10 VI 2014, obs. AM; Ustrzyki Górne (FV24), 3 IV 1968 - 1 ex., log of Alnus sp. lying on the ground, leg. BB [MIZ], 19 VI 1977 - 3 exx., ex coll. AEBG [MNHW]; Widełki for. div., comp: 23a, 28a, 93g, (FV24), 7 VII-23 IX 2013 - more than 10 exx. under the bark of firs Abies alba, obs. AM; Zatwarnica vic., Dolina Hylaty (FV15), 8 VI 
2013 - 1 ex., on a spruce log, leg. JTD; Żubracze for. div. (EV95), VII 2015 - 1 ex., leg. AM.

Distribution. Species inhabiting the whole of Europe, rarely observed in Poland. Known mainly from the east of the country and the Świętokrzyskie Mts. A relict of primeval forests. Recently recorded from the Świętokrzyskie Mts. and Suchedniów Plateau (Płaskowyż Suchedniowski) (BuchHOlz, BIDAS 2012), Białowieża Forest (Plewa et al. 2015), Roztocze (PAPIS, MOKRZYCKI 2015) and Bieszczady Mts. (HOLLY 2016). Nowadays it occurs only in eastern Poland. Historical records from the Sudeten Mts. in western Poland have not been confirmed for many years. Newly recorded in the Mazovian Lowland and Małopolska Upland (Fig. 11).

Biology. Develops in soft, rotten wood overgrown with fungi. According to BOROWSKI (2006) it is monophagous on Fomitopsis pinicola. Associated with firs and spruces in montane forests but also with other species of trees, e.g. birches (Fig. 12) (BURAKOWSKI et al. 1986, KoliBÁČ et al. 2005, this study). According to the present data (Tab. 1), it shows a strong preference for firs (63\% of records). Adults can be observed throughout the year in feeding galleries and places of concealment - under bark and in deadwood of both snags and fallen trees, also in windthrows, tree stumps, and thick branches; the beetles are active from the end of April until mid-July, mainly in May and June.

\section{Family: Thymalidae \\ Thymalus limbatus (FABRICIUS, 1787)}

Material examined. Baltic Coast: Międzyzdroje (VV67), 3 VI 1998 - 1 ex., leg. HS; Wolin Is., Lubiń (VV66), 3 V 1991 - 2 exx., 31 VII-8 VIII 1991 - 21 exx., leg. MW; Wolin Is., Międzyzdroje (VV67), 21 VII 2000 - 4 exx., mixed coniferous forest, under bark, leg. AL. Pomeranian Lake District: Drawieński NP, "Radęcin" strict protection area (WU68), 4 V 2013 - 1 ex., leg. RR. Mazovian Lowland: Otwock [Jabłoń] (EC17), 16 VIII 1900 - 1 ex., leg. WM [USMB]. Podlasie: Knyszyn Forest, "Krzemienne Góry" res. (FD69), 26 V 2011 - 1 ex., leg. JMG. Bialowieża Primeval Forest: Białowieża NP, Zamosze vic., Głuszec (FD95), 29 V 2016 - 1 ex., leg. RR; Białowieża NP, comp. 224 (FD95), 5 VI $1954-2$ exx., under the bark of spruce, leg. BB [MIZ]; Białowieża NP, comp. 256C (FD95), $6 \mathrm{~V} 1992-1$ ex., leg. JMG [ISEA]; Białowieża NP, comp. 288C/318A (FD94), mixed coniferous forest, 15 V 1990 - 1 ex., 18 VII 1995 - 1 ex., in turpentine baited (the first specimen) and unbaited (the second specimen) IBL-2bis barrier traps, 29 V 2001 - 1 ex., 24 V $2002-1$ ex., 19 V 2005 - 1 ex., 2 VI 2005 - 1 ex., 24 V 2007 - 1 ex., 29 V 2008 - 1 ex., 11 VI 2009 - 2 exx., 9 VII 2009 - 1 ex., 20 VII 2011 1 ex., 9 V 2012 - 2 exx., 23 V 2012 - 1 ex., in unbaited IBL-2bis barrier traps, 7 VI 2007 1 ex., in a Netocia trap, leg. JMG; Białowieża NP, comp. 316 (FD94), 17 VI 1996 - 1 ex., 
oak-hornbeam forest, on Laetiporus sulphureus, leg. KSU [AL]; Białowieża NP, comp. 318A (FD94), Querco-Piceetum, 24 V 2007 - 1 ex., in a Netocia trap, 25 VI 2009 - 1 ex., in an IBL-2bis barrier trap, leg. JMG; Białowieża NP, comp. 399 (FD94), 18 VI 1991 1 ex., leg. MW; Białowieża NP, comp. 399C (FD94), oak-hornbeam forest, 24 V 1994 1 ex., in an IBL-2bis barrier trap, leg. JMG; Białowieża NP, comp. 400 (FD94), 1 VIII 1982 - 4 exx., leg. MW; Białowieża NP, comp. 400D (FD94), 24 VI 1997 - 1 ex., leg. RK; Białowieża NP, 15-27 VI 1991 - 3 exx., leg. LB [RR]; Białowieża NP/for. distr. Białowieża, Droga Browska, comp. 374D/403B (FD94), 21-27 VI 2001 - 1 ex., in an IBL2 bis barrier trap, leg. JMG; Białowieża NP/for. distr. Białowieża, Droga Browska, comp. 375B/375D (FD94), 4-10 VI 1997 - 3 exx., 22-28 VII 1998 - 1 ex., 2-8 VI 1999 - 2 exx., in IBL-2bis barrier traps, leg. JMG; Białowieża, Palace Park (FD94), 18 IX $2004-1$ ex., leg. RR; for. distr. Białowieża, ad Teremiski (FD84), oak-hornbeam forest, 8 VI 2015 1 ex., in an IBL-2bis barrier trap, leg. JMG; for. distr. Białowieża, Białowieża-Krzyże vic. (FD94), 19 V 2017 - 6 exx., on an oak Quercus sp. overgrown with fungi (at night), leg. JTD; for. distr. Białowieża, comp. 494C (FD84), 8 VI 2000 - 2 exx., leg. JMG [ISEA]; for. distr. Browsk, comp. 156 (FD85), 26 VI 1991 - 1 ex., leg. TM [ISEA]; ad Nowosady, Bagna Derlicz vic. (FD75), 19 V 2017 - 1 ex., on the trunk of a spruce Picea abies, leg. JTD. Trzebnica Hills: Skoroszów vic. (XS56), beech forest, 15 VIII 2006 - 1 ex., leg. RR. Kraków-Wieluń Upland: Kraków-Las Wolski (DA14), $24 \mathrm{~V}$, year unknown (end of $19^{\text {th }}$ century) - 5 exx., leg. MR [ISEA]. Świętokrzyskie Mts.: Łysa Góra (EB03), 15 IX 1968 2 exx., under the bark of Abies alba, leg. BB [MIZ]; Góry Świętokrzyskie, Łysa Góra Mt. (EB03), 3 VI 1956 - 1 larva (imago: 14 VI 1956), leg. BB [MIZ]; Huta Szklana vic. (EB03), 10 V 2002 - 3 exx., leg. RR; Św. Katarzyna (DB93), 13 VII 2014 -2 exx., leg. JG; Św. Krzyż, 21 V 1982 - 1 ex., leg. LB [RR]; Świętokrzyski NP, comp. C-1 (DB93), 8 VIII 1962 - 2 exx., leg. MBM [MIZ]; Świętokrzyski NP, Łysica-Św. Krzyż protected area (DB93), 3 V 2010 - 2 exx., leg. MM \& LBU; Świętokrzyskie Mts., 25 VI 1983 - 1 ex., leg. JKM [ISEA]. Roztocze: Roztocze NP, "Nart" strict protection area [Nart g. Lubelska] (FB40), 15 VII 1910 - 1 ex., ex coll. ST [MIZ], 1 ex., in a bracket fungus, ex coll. FF [MIZ]; Zwierzyniec, Bukowa Góra (FB30), 24 VI $1902-2$ exx., leg. WM [USMB]; Zwierzyniec [Zwierzyniec Lubelski] (FB30), 15 VI 1914 - 1 ex., ex coll. FF [MIZ]. Western Sudeten Mts.: Wolibórz (XS10), 4-5 VII 1996 - 12 exx., several hundreds of beetles were observed in the middle of the day, swarming on fruiting bodies of Fomes fomentarius growing on the basal part of an old Fagus sylvatica trunk, leg. HS. Eastern Sudeten Mts.: Góry Bialskie, Puszcza Jaworowa (XR46),7 VII 1993 - 4 exx., leg. LB. Western Beskid Mts.: Beskid Wołosacki Mt. (FV23), 22 VII $1880-1$ ex., leg. BK [ISEA]; Bircza (FA00), Panieński Czub Mt., 22 V 1879 - 1 ex., leg. BK [ISEA]; Barania Góra (CV59), VII 1876 - 1 ex., leg. BK [ISEA]; "Barania Góra” res. (CV59), 25 VII 1997 - 3 exx., under loose bark on a dead Picea abies, leg. HS; Silesian Beskids, Czantoria vic. 
(CA40), 31 VII 2000 - 1 ex., leg. RR; Czantoria Mt. (CA40), VII-VIII 1884 - 2 exx., 21 VIII 1886 - 1 ex., 1887 - 8 exx. leg. BK [ISEA]; Radziejowa Mt. (DV77), 8 VII 1901 4 exx., leg. SAS [ISEA]; Roztoka Wielka (DV78), 9 VI 1896 - 1 ex., 12 IV 1899 - 1 ex., 15 VII 1901 - 4 exx. leg. SAS [ISEA]; Równica Mt. (CA40), VIII 1884 - 6 exx., leg. BK [ISEA]; Rytro (DV78), 20 VI 1919 - 3 exx., leg. SAS [ISEA], 21 VII 1902 - 1 ex., leg. WM [USMB]; Skrzyczne Mt. (CA50), VIII $1884-21$ exx., leg. BK [ISEA]; Tuł Mt. (CA30), 1888 - 1 ex., leg. BK [ISEA]. Eastern Beskid Mts.: Długie vic. (EV27), 24 VI $2014-1$ ex. under the bark of a standing beech stump with a diameter of over $100 \mathrm{~cm}$, leg. AM; for. distr. Bircza: Borysławka for. div., the Kanasin Mt., southern slopes, comp. 115a (FV19), 14 VII-3 VIII 2015 - 1 ex., in an IBL-2 barrier trap suspended from a fir snag in Carpathian beech forest, leg. TN [KR]; for. distr. Krasiczyn, Krzeczkowa for. div., comp. 230h (FA11), VI 2012 - 1 ex., leg. AM; Hałbowska Pass vic. (EV38), 10 V-10 VI 2014 1 ex., in an IBL-5 barrier trap suspended from a fir tree Abies alba trunk, leg. AM; Hołubla (FA11), 31 V 1884 - 1 ex., leg. BK [ISEA]; Huta Krempska vic. (EV38), 17 VII 2014 1 ex., under the bark of a fir snag Abies alba $45 \mathrm{~cm}$ in diameter, leg. AM; Huwniki (FA20), 5 V-7 VI 2016 - 1 ex., in an IBL-2 barrier trap, leg. AM [HS]; Jureczkowa for. div., the north-eastern slope of Żupa Mt., comp. 204s (FV18), 26 V-15 VI 2015 - 4 exx., in an IBL5 barrier trap suspended from a fir snag in Carpathian beech forest with admixed sycamore Acer pseudoplatanus L., leg. TN [KR]; Las Karaszyn (FV18), for. distr. Bircza, for. div. Jureczkowa, comp. 191, 5 IX 2013 - 3 exx., under the bark of Abies alba, leg. TO; Kuszmień Mt. (FV17), 19 VII 1884 - 1 ex., leg. BK [ISEA]; Magura NP: Baranie massif (EV47), 29 III 2014 - 1 ex., under the bark of a dead Acer pseudoplatanus, leg. MM et LBU; Magura NP, Ciechania (EV37), 7 VII 2014 - 1 ex., under a bracket fungus on a wind-thrown beech (fallen timber) - Fagus sylvatica, leg. AM; Olszany (FA11), 1877 4 exx., leg. BK [ISEA]; Pacław (FV29), forest, 5 VI 2015 - 1 ex., in an IBL-5 barrier trap on Quercus robur, leg. TO; Przemyśl vic. (FA21*), 25 exx., leg. TT [ISEA]; "Przełom Jasiołki" res. (EV57), 27 V 2016 - 1 ex., in an IBL-2 barrier trap on Abies alba, leg. TO; "Reberce" res. vic. (FA10), 1 VI 2016 - 1 ex., leg. TN [HS]; Roztoka (FV09), 1 VI 2016 2 exx., 2 VI. 2016 - 2 exx., leg. MB [HS]; Spława Mt. (FA10), 6 VII 1884 - 4 exx., leg. BK [ISEA]; Trójca for. div., comp. 461 (FV19), 26 V-15 VI 2015 - 1 ex., in an IBL-5 barrier trap suspended from a fir above the Jamninka stream, leg. TN [KR]; Turnica for. div., Suchy Obycz massif, northern slopes of the Niemiecka Valley, comp. 162a (FV19), 27 IV-27 V 2015 - 1 ex., in an IBL-2 barrier trap suspended from beech trees in Carpathian beech forest with admixed fir, leg. TN [KR]. Bieszczady Mts.: Cisna for. distr., Roztoki for. div., comp. 169a, (EV94), 29 VII 2015 - 1 ex., obs. AM; Lutowiska for.distr., Paniszczew for. div., comp. 115b (FV06), 29 V 2014 - 1 ex., leg. AM; Lutowiska for.distr., Paniszczew for. div., comp. 116 (FV06), 24 V 2014 - 2 exx., under the bark, leg. AM; Polana for. div., comp. 80B-a (FV16), 15 V-10 VI 2014 - 1 ex., leg. AM; Połonina 
Caryńska Mt. (FV24), 2 VI 2001 - 1 ex., leg. HS; Rosochate for. div., comp. 96c (FV15), 1 VII-23 IX 2013 - 1 ex., leg. AM; Bieszczadzki NP; Ustrzyki Górne (FV24), 24-27 V 1996 - 1 ex., 26 V 1997 - 1 ex., leg. HS. Pieniny Mts.: Pieniny NP, Burzana vic. (DV57), 20 VII 2017 - 1 ex., on Polyporus squamosus (HUDS.) QUÉL. growing on a beech in an old beech and fir forest, leg. PCH [PNPM]; Pieniny, Pustelnia Św. Kingi (DV57), 1 VI $1929-$ 1 ex., coll. ST [MIZ]; Potok Pieniński (DV57), 26 V 1912 - 1 ex., ex coll. ST [MIZ]. Tatra Mts.: Kościeliska Valley (DV15), 4 VII 1939 - 1 ex., leg. SAS [ISEA]; Liliowe (DV25), 8-10 VIII 1879 - 2 exx., leg. BK [ISEA].

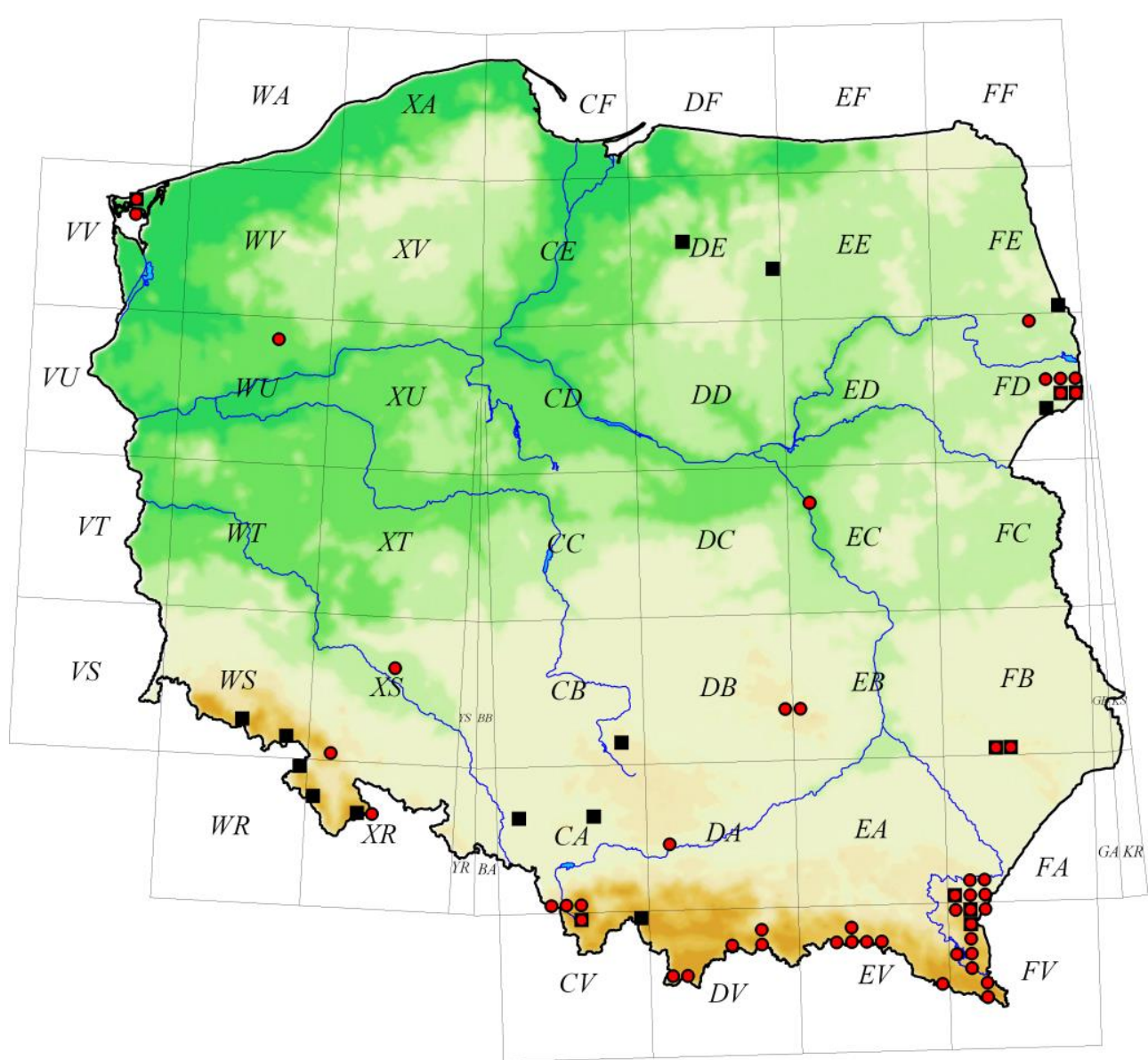

Fig. 13. Thymalus limbatus (published records - black squares, records reported in the present paper - red circles) - distribution in Poland. 
Distribution. Widely distributed in Europe, reaching northern Africa. Rarely collected in Poland - a relict of natural forests. Recorded in radiocarbon-dated subfossil remains from ca. 10000 BP (PAWŁOWSKI \& KUŚKA 1987). Occurs in southern Poland, the Białowieża Forest and scattered localities in the lowlands. Recently recorded in the Białowieża Forest and Podlasie (PlewA et al. 2014). New records from the Pomeranian Lake District, Mazovian Lowland, Trzebnica Hills and Tatra Mts. (Fig. 13).

Biology. A fungivorous species associated with trees of numerous species, mostly broadleaved (beech, birch, lime) but also coniferous (spruce) (BURAKOWSKI et al. 1986, KoliBÁČ et al. 2005, this study). Both adults and larvae feed on wood overgrown with fungi. Sometimes, the beetles are attracted in great numbers to the sporocarps (see above the record by HS from Wolibórz). Adults can be observed throughout the year in feeding galleries or in places of concealment; the beetles are active from mid-May until the beginning of August. According to the present data (Tab. 1), it prefers fir (28\% of records) and beech $(23 \%)$.

\section{DISCUSSION}

Species of Trogossitidae, Lophocateridae, Peltidae and Thymalidae are associated with forests and have various habitat preferences. Several species, like Calitys scabra, Grynocharis oblonga, Peltis ferruginea, P. grossa and Thymalus limbatus are mycophagous, while others, like Nemozoma caucasicum, N. elongatum, Temnoscheila caerulea and Tenebroides mauritanicus are predators. Two species, Lophocateres pusillus and occasionally also $T$. mauritanicus, have been recorded as pests of stored products.

The amount of data collected in the present paper allowed us to analyse the habitat preferences of these beetles. Data on preferred trees were analysed for 290 records and 7 species (Tab. 1). The most ubiquitous species was G. oblonga, which was found on 22 genera of trees. Nemozoma caucasicum is strictly associated with ash (Fraxinus excelsior) in Poland, although the number of available records was small. Both species of Peltis preferred coniferous trees - spruces and firs. In contrast, Tenebroides mauritanicus and Grynocharis oblonga were associated with deciduous trees. Two species - Nemozoma elongatum and Thymalus limbatus - occurred on deciduous and coniferous trees with similar frequencies. The most attractive trees for these beetles were fir ( 6 species), spruce and oak (each with 5 species), and beech (4 species). Grynocharis oblonga occurred on adventive species, like Aesculus hippocastanum, Philadelphus sp., Juglans regia, Platanus orientalis, Robinia pseudoacacia, and on fruit trees. In most cases, it was the only representative of the beetle families examined here on these tree taxa. 
Table 2. Observations of beetles in natural forests, managed forests, and anthropogenic localities; based on original data (total number of localities analysed: 133). Abbreviations: $\mathrm{NP}$ - number of localities in natural and protected forests, NM - number of localities in managed forests, $\mathrm{A}-$ number of anthropogenic localities (avenues, parks), $\sum-$ sum.

\begin{tabular}{|c|c|c|c|c|}
\hline Species & NP & NM & $\mathbf{A}$ & $\sum$ \\
\hline Nemozoma elongatum & 8 & 3 & 1 & 12 \\
\hline Tenebroides mauritanicus* & 7 & 2 & 13 & 22 \\
\hline Grynocharis oblonga & 17 & 6 & 15 & 38 \\
\hline Peltis ferruginea & 30 & 5 & 0 & 35 \\
\hline Peltis grossa & 13 & 3 & 0 & 16 \\
\hline Thymalus limbatus & 12 & 1 & 0 & 13 \\
\hline$\sum=$ & 86 & 18 & 29 & 133 \\
\hline
\end{tabular}

* records from synanthropic localities have been omitted

Table 3. Species included in red lists in Central Europe. Abbreviations: PL - Poland (PAWŁOWSKI et al. 2002/Rossa 2004); Ge - Germany (GEISER 1998); IUCN - IUCN red list, $\mathrm{P} / \mathrm{V}$ - restricted to primeval/virgin forests; CR - critically endangered; EX? - probably extinct, 1 - vom Aussterben bedroht $(=\mathrm{CR}) ; 2-$ stark gefährdet $(=\mathrm{EN}) ; 3$ - gefährdet (= VU, vulnerable), LC - least concern, DD - data deficient.

\begin{tabular}{lcccl}
\hline \multicolumn{1}{c}{ Species } & PL & Ge & IUCN & \multicolumn{1}{c}{ P/V } \\
\hline Calitys scabra & CR/EX? & 1 & - & - \\
Grynocharis oblonga & - & 2 & LC & ECKELT et al. (2018) \\
Peltis ferruginea & - & 2 & LC & KOLIBÁČ et al. (2005) \\
Peltis grossa & VU/- & 1 & - & KOLIBÁČ et al. (2005) \\
Temnoscheila caerulea & EX?/- & - & - & - \\
Tenebroides mauritanicus & - & 2 & DD & BURAKOWSKI et al. (1986) \\
Thymalus limbatus & - & 3 & LC & KOLIBÁČ et al. (2005) \\
\hline
\end{tabular}

Data on habitat preferences were analysed for 133 localities and 6 species (Tab. 2). Synanthropic habitats, like stores and flats, were not included in the analysis. There were only a small number of records from managed forests, quite possibly because of the greater interest among entomologists in the exploration of natural forests and protected areas. Despite this bias, we think that the results of this analysis are worth publishing. Forest habitats were divided into three categories: natural forests, managed forests and anthropogenic tree stands like avenues and parks. Grynocharis oblonga and Tenebroides mauritanicus were observed in anthropogenic tree stands and in managed forests more often than other species. Nemozoma elongatum was most frequently recorded in natural 
forests, and only exceptionally in anthropogenic sites. The other three species - Peltis ferruginea, P. grossa and Thymalus limbatus - were never collected in avenues or parks, and only rarely collected in managed forests; they were usually recorded in natural forests, often with large volumes of deadwood. Our results confirm the data published by KoLIBÁC̆ et al. (2005) (Tab. 3), but do not justify treating either G. oblonga or Tenebroides mauritanicus as relicts of primeval forests (BURAKOWSKI et al. 1986, ECKELT et al. 2018).

The occurrence of two of the species in question here - Calitys scabra and Temnoscheila caerulea - has not been confirmed in Poland for over 100 years. Grynocharis oblonga, Nemozoma elongatum and Tenebroides mauritanicus are relatively common. Peltis ferruginea, P. grossa and Thymalus limbatus are more or less rare and larger numbers of individuals are observed only occasionally. Nemozoma caucasicum is a very interesting species, described in 1832 from the Caucasus, which has expanded its range in recent decades, although it was recorded in France as early as in 1927.

Several species from these four families are included in red lists of endangered species in Europe (GeISER 1998, PaWŁowski et al. 2002, NieTo \& AleXANDER 2010). The categories of threat on the Polish Red List (PAWŁOWSKI et al. 2002) appear to be correctly assigned to these species, but we think that Peltis ferruginea and Thymalus limbatus should be added to the list. The IUCN and German red lists (GEISER 1998) include two species that are common in Poland, namely, Grynocharis oblonga and Tenebroides fuscus; this is probably justified in view of the deteriorating conditions of habitats in western Europe. Stenotopic species, like Calitys scabra, Peltis ferruginea, P. grossa, Temnoscheila caerulea and Thymalus limbatus, can be used as indicator species of natural forests. While Calitys scabra and Temnoscheila caerulea are probably extinct in Poland, other species, like Peltis ferruginea, P. grossa and Thymalus limbatus, are quite often observed in natural forests. All these species are relatively abundant in the Białowieża Forest, Świętokrzyskie Mts., Roztocze and Carpathians Mts. Numerous localities are protected in national parks and nature reserves, but as a consequence of the intensification of forest management, we feel it is reasonable to establish other areas protecting their populations. One such area is the proposed Turnica National Park, which should protect one of the best-preserved mountain forests in Poland (DEMBEK et al. 2014) and one of the most important areas for endangered invertebrates (including Coleoptera) in central Europe (BUCHHOLZ \& MELKE 2018).

The genus Thymalus LATREILLE, 1802 requires a systematic revision of specimens collected throughout its range. The occurrence of Thymalus oblongus REITTER, 1889 in Poland seems plausible, as the species has already been recorded in Scandinavia and the European part of Russia (KOLIBÁČ 2007). In the authors' opinion, however, the existing literature does not permit certain identification of this species.

Ancyrona japonica REITTER, 1889, originally an Asian species, was introduced to several European countries. It became acclimatised in Slovakia, Hungary, Czechia and 
probably also in Bulgaria, as it has been regularly collected there since 1904 (KOLIBÁČ 2013). It is likely that the species is already present in Poland, as the known localities are situated in neighbouring countries. The larval characters of Ancyrona are described in KoliBÁČ (2006), and KoliBÁČ \& ZAITSEV (2010), but especially in the case of the early instars, identification may be doubtful or even impossible when using the existing keys (KLAUSNITZER 1996). The morphology of immatures of Ancyrona REITTER, 1876 and Grynocharis C.G. THOMSON, 1859 requires further study.

\section{ACKNOWLEDGEMENTS}

The data from the Przemyśl Foothills obtained in 2011-2016 come from the inventory of saproxylic beetles carried out for the purposes of establishing the Turnica National Park (the National Park of the Carpathian Foothills) and the planned "Carpathian Forest" ("Puszcza Karpacka") nature reserve. The project was implemented with financial support from the "Natural Heritage" Foundation and the WWF Poland Foundation.

The data from the Bieszczady Mountains come from the inventory of saproxylic species including indicators of natural forests within the Lutowiska and Stuposiany Forest District (2013-2014) and from the Cisna and Komańcza Forest District (2015) in the Natura 2000 area PLC180001 Bieszczady. The project was financed by the Natural Heritage Foundation (Fundacja Dziedzictwo Przyrodnicze) and the WWF Poland Foundation.

The information from the Magura NP (2014) comes from an inventory of beetles carried out as a part of the work on the Protection of the Magura NP Fauna and the Protection Plan for the "Ostoja Magurska" Natura 2000 site. The project was carried out for the Institute of Nature Conservation, Kraków, and the Natural Heritage Foundation.

The materials from the environs of Pacław were collected by Tomasz OLBRYCHT in 2015-2016 within the framework of project No. DEC-2013/11/B/NZ9/00793, financed by the National Centre of Science.

The data from the Pieniny NP (2017) come from the project: "Beetles (Coleoptera) inhabiting fruiting bodies of fungi (Macromycetes) in the Pieniny National Park", which was co-financed from the forest fund.

We would like to thank Edward BARANIAK, Adam BOHDAN, Lech BOROWIEC, Lech Buchholz, Tadeusz Bziuk, Piotr ChachUŁa, Roland Dobosz, Paweł JaŁoszyński, Tomasz KoścIELnY, Wojciech KubAsIK, Krzysztof LubECKI, Jerzy ŁugOwoJ, Tomasz MaJEWSKi, Tomasz NabiaŁKowski, Radosław Plewa, Stanisław SzAFranieC, Krzysztof SUĆKO and Katarzyna ŻUK for making their collections available for the present study.

We thank Tomasz Huflejt and Przemysław SZYMroszczYK for allowing Marek MiKKOWSKI and Jan TATUR-DYTKOWSKI to study the collection of the Museum and 
Institute of Zoology, Polish Academy of Sciences (Łomna-Las). Jan TATUR-DYTKOWSKI is also grateful to Maria KoŚCIESZA and Monika MALCHER from the Library of the Museum and Institute of Zoology, Polish Academy of Sciences (Warsaw), for their great support in the search for historical literature. We extend our gratitude to Stephan BLANK and Lutz BEHNE for their kind assistance during the visit of Rafał RUTA to the Senckenberg Deutsches Entomologische Institut, Müncheberg, in December 2018.

Finally, we thank Paweł JAŁOSZYŃSKI for sharing information on the larval morphology of Lophocateridae.

\section{REFERENCES}

ALBIEN W. 1905. Sammelbericht über meine im Sommer 1903 ausgeführte Exkursion in die Kreise Thorn und Briesen. Bericht des Westpreussischen Botanish-Zoologischen Vereins, 26-27: 13-25.

BaŁaZY S., Michalski J. 1977. Studies on xylophagous fauna of the Wielkopolski National Park, II. Badania Fizjograficzne nad Polską Zachodnią, ser. C, Zoologia, 30: 99-107. (in Polish)

Bercio H., Folwaczny B. 1979. Verzeichnis der Käfer Preussen. Verlag Parzeller \& Co., Fulda.

Borowiec L. 1983. Beetles - Coleoptera. Peltidae. Keys for the Identification of Polish Insects, XIX, 69: 1-16. (in Polish)

Borowiec M.L. 2007. Camponotus truncatus (SPINOLA, 1808) (Hymenoptera: Formicidae) - ant species new to Poland. Polish Journal of Entomology, 76 (1): 41-45.

BOROWSKI J. 2001. An attempt of valorization of woods of the Białowieża Primeval Forest using beetles realeted to arboreal mushroms. [in:] A. SzUJECKI (ed.). An attempt of estimated valorization of woods of the Białowieża Primeval Forest using the zooindication method. Wydawnictwo SGGW, Warszawa, 287-317. (in Polish)

Borowski J. 2006. Beetles (Coleoptera) of the tree-fungi - a valorization study. Wydawnictwo SGGW, Warszawa. (in Polish)

Bouchard P., Bousquet Y., Davies A.E., Alonso-Zarazaga M.A., Lawrence J.F., Lyal Ch.H.C., Newton A.F., Reid Ch.A.M., Schmitt M., Ślipiński S.A., SMith A.B.T. 2011. Family-group names in Coleoptera (Insecta). ZooKeys, 88: 1-972.

BRUSTEl H., Rogé J. 2011. Le genre Nemozoma LATREILLE, 1804: clé des espèces ouest-paléarctiques et présence en France de $N$. caucasicum MÉNÈTRIÈs, 1832 (Coleoptera, Trogossitidae). Bulletin de la Société entomologique de France, 116 (4): 453-462.

BuchHolz L. 2004. Lacon lepidopterus (PANZER, 1801). [in:] Z. GŁowACIŃSKI, J. NowACKi (eds.) Polish Red Data Book of Animals. Invertebrates. Instytut Ochrony Przyrody PAN, Akademia Rolnicza im. A. Cieszkowskiego, Kraków - Poznań, 122-123. (in Polish)

BuchHOlZ L., Bidas M. 2012. The occurrence of some interesting saproxylobiontic beetles (Coleoptera) in the Świętokrzyskie Mountains and on the Suchedniów Plateau. Wiadomości Entomologiczne, 31 (4): 291-295. (in Polish) 
Buchrolz L., Melke A. 2018. Beetles (Insecta: Coleoptera) of the planed Turnicki National Park (the Carpathian Foothills National Park) and its buffer zone. [in:] M.D. BoćKOwSKI (ed.). Planed Turnicki National Park. The state of natural values - 35 years from the first plan of the national park in the Carpathian Foothills. Fundacja Dziedziwctwo Przyrodnicze, Nowosiółki Dydyńskie, 314-377. (in Polish)

Burakowski B., Mroczkowski M., Stefańska J. 1973. Beetles - Coleoptera, Ground beetles Carabidae, part 1. Catalogue of Polish Fauna, 23 (2): 1-184. (in Polish)

Burakowski B., Mroczkowski M., Stefańska J. 1986. Beetles - Coleoptera. Dermestoidea, Bostrichoidea, Cleroidea and Lymexyloidea. Catalogue of Polish Fauna, 23 (11): 1-244. (in Polish)

BYк A. 2001. An attempt to valorize stands of older age classes of the Bialowieza Forest based on the structure of beetles (Coleoptera) associated with decomposing wood trunks of dead standing trees and hollows. [in:] A. SzUJECKI (ed.). An attempt of estimated valorization of woods of the Białowieża Primeval Forest using the zooindication method. Wydawnictwo SGGW, Warszawa, 333-367. (in Polish)

BYK A. 2007. Valorisation of forests of the Świętokrzyskie Mountains based on the structure of assemblages of saproxylic beetles. [in:] J. BOROwSKI, S. MAZUR (eds.). Valorization of the forest ecosystems of the Świętokrzyskie Mountains based on zooindication method. Wydawnictwo SGGW, Warszawa, 57-118. (in Polish)

BYк A., BYк S. 2004. Saproxylic beetles of the nature reserve "Dęby w Krukach Pasłęckich". Parki Narodowe i Rezerwaty Przyrody, 23 (4): 555-580. (in Polish)

BYk A., PerLiński S., RUTKIEWICZ A. 2006. Saproxylic beetles - in the monitoring of anthropogenic transformations of Białowieża Primeval Forest. [in:] A. SzuJecki (ed.). Zooindication-based monitoring of anthropogenic transformations in Białowieża Primeval Forest. Warsaw Agricultural University Press, Warszawa, 325-397.

CAPECKI Z. 1969. Die holzbeschädigengen Insekte der Rotbuche (Fagus silvatica L.) innerhalb ihrer naturalichen Verbreitung in Polen. Prace Instytutu Badawczego Leśnictwa, 367: 3-166. (in Polish)

Crowson R.A. 1970. Further observations on Cleroidea (Coleoptera). Proceedings of the Royal Entomological Society of London. Series B, 39 (1-2): 1-20.

Dembek W., Melke A., Michalski R., Przewoźny M. 2014. The need to establish the National Park of the Carpathian Foothills: 101-114. [in:] Z. MiREK, A. NiKel (eds.). Nature Conservation in Poland and Current Civilizational Challenges. Komitet Ochrony Przyrody PAN, Kraków, 1-301. (in Polish)

DoRn K. 1919. Sammelbericht aus dem Warthelager bei Posen. Entomologisches Jahrbuch, 28: 124133.

Eckelt A., Müller J., Bense U., Brustel H., Bubler H., Chittaro Y., Cizek L., Frei A., Holzer E., Kadej M., Kahlen M., Köhler F., Möller G., Mühle H., Sanchez A., Schaffrath U., Schmidl J., Smolis A., Szallies A., Németh T., Wurst K., Thorn S., Christensen R.H.B., SEIBOLD S. 2018. "Primeval forest relict beetles" of Central Europe: a set of 168 umbrella species for the protection of primeval forest remnants. Journal of Insect Conservation, 22 (1): 15-28.

Fein A., HAASE E. 1881. Beobachtungen über Fundorte und Fangzeiten einiger interessanteren oder selteneren schlesischen Käfer. Zeitschrift für Entomologie, N.F., 8: 18-27. 
Geiser R. 1998. Rote Liste der Käfer (Coleoptera). [in:] M. BinOt, R. Bless, P. Boye, H. GRUtTKe, P. PRETSCHER (eds.). Rote Liste gefährdeter Tiere Deutschlands. Schriftenreihe für Landschaftspflege und Naturschutz, 55: 168-230.

GERHARDT J. 1910. Verzeichnis der Käfer Schlesiens preussischen und österreichischen Anteils, geordnet nach dem Catalogus coleopterorum Europae vom Jahre 1906. Julius Springer, Berlin.

GIDASZEWSKI A. 1974. An analysis of the occurrence and salubrity of Tomicus piniperda (L.) and T. minor (HRTG.) in forest stands of Wielkopolski National Park during the years 1969-1970. Polish Journal of Entomology, 44 (4): 789-815. (in Polish)

Gimmel M. L., Bocakova M., Gunter N. L., Leschen R. A. B. 2019. Comprehensive phylogeny of the Cleroidea (Coleoptera: Cucujiformia). Systematic Entomology, 44 (3): 527-558.

GRZYwocz J., SzOŁTYs H. 1996. Materials to the knowledge of Upper Silesian beetles (Coleoptera. Acta entomologica Silesiana, 4 (1-2): 14-18. (in Polish)

Gutowski J.M., BuchHolz L., Kubisz D., OssowsKa M., SućKO K. 2006. Saproxylic beetles as indicator of deformation of pine forest ecosystems. Leśne Prace Badawcze, 4: 101-144. (in Polish)

HiLsZCZAŃSKI J. 2006. Nemosoma caucasicum MeNETRIES, 1832 (Coleoptera: Trogossitidae) - new beetle to the Polish fauna. Wiadomości Entomologiczne, 25 (1): 29-32. (in Polish)

HilsZCZAŃSKi J., JAWORSKi T., PleWA R., HoRÁK J. 2016. Tree species and position matter: the role of pests for survival of other insects. Agricultural and Forest Entomology, 18 (4): 340-348.

Holly M. 2016. Rare and new for the fauna of the Bieszczady Mts species of beetles (Coleoptera) recorded from the Bieszczady National Park and its buffer zone in the years 2012-2015. Roczniki Bieszczadzkie, 24: 199-213. (in Polish)

HORION A. 1960. Faunistik der mitteleuropäischen Käfer. Band VII: Clavicornia 1. Teil (Sphaeritidae bis Phalacridae). A. Feyel Verlag, Überlingen-Bodensee.

IUCN 2017. The IUCN red list of threatened species.Version 2018-2. [http://www.iucnredlist.org/] [access 28.11.2018].

JABŁOŃSKI W. 1869. A contribution to the fauna of domestic beetles. Sprawozdanie Komisji Fizjograficznej, 3: 68-73. (in Polish)

Janicki J., KadŁubowski W., Kięczewski B., Matuszewski A. 1959. A contribution to the study of the species composition of insects and mites in some cereal warehouses in the Poznan province. Roczniki WSR Poznań, 6: 41-50. (in Polish)

JANNSON A. 1925. Die Insekten-, Myriapoden- und Isopodenfauna der Gotska Sandön. Lanstidningens Tryckeri, Örebro.

Kelch A. 1846. Grundlage zur Kenntniss der Käfer Oberschlesiens, insonders der Umgegend von Ratibor. [in:] Zu der öffentlichen Prüfung aller Classen des Königlichen Gymnasiums zu Ratibor den 4. und 7. April, und dem mit Entlassung der Abiturienten verbundenen Redeactus den 20. April laden ergebenst ein Director und Lehrer-Collegium. Böner's Erben, Ratibor, 1-54.

KLAuSNitZER B. 1996. 14. Überfamilie: Cleroidea. [in:] B. KLAuSNitZER (ed.). Die Larven der Käfer Mitteleuropas. Band 3. Goecke \& Evers, Krefeld. Gustav Fischer Verlag, Jena-Stuttgart, 144 216.

KolibáČ J. 1993. Phloiophilidae. Trogositidae. Cleridae. [in:] J. JelíneK (ed.). Check-list of Czechoslovak Insects IV (Coleoptera). Folia Heyrovskyana, Suppl. 1: 89-90. 
KoliBÁČ J. 2006. A review of the Trogossitidae. Part 2: Larval morphology, phylogeny and taxonomy (Coleoptera, Cleroidea). Entomologica Basiliensia et Collectionis Frey, 28: 105-153.

KolibáČ J. 2007. Trogossitidae. [in:] LöBl I., Smetana A. (eds.). Catalogue of Palaearctic Coleoptera, Vol. 4. Stenstrup, Apollo Books, 364-366.

KoliBÁČ J. 2013. Trogossitidae: A review of the beetle family, with a catalogue and keys. Zookeys, 366: $1-194$.

KolibÁČ J., Majer K., Švihla V. 2005. Cleroidea. Beetles of the superfamily Cleroidea in the Czech and Slovak Republics and neighbouring areas. Clarion Production, Praha.

KolibÁČ J., ZAitsev A.A. 2010. A description of a larva of Ancyrona diversa PIC, 1921 and its phylogenetic implications (Coleoptera: Trogossitidae). Zootaxa, 2451: 53-62.

KONWERSKI S. 1997. Interesting beetle species (Coleoptera) found in the western part of Wołyn and in the Beskid Niski mts. [in:] K. LATOwsKI (ed.). Studies on flora and fauna (bioindication, biodiversity, research methods). Bogucki Wydawnictwo Naukowe, Poznań, 81-84. (in Polish)

Kotula B. 1873. Contribution to the fauna of beetles of Galicja. Sprawozdanie Komisji Fizjograficznej, 7: 58-90. (in Polish)

KUBISZ D. 1995. Coleoptera of selected families as an element of ecological monitoring in Białowieża Primeval Forest. Prace Instytutu Badawczego Leśnictwa, Seria A, 797: 161-176. (in Polish)

KuBISZ D. 2004. Coleoptera of selected families as an element of ecological monitoring in the Białowieża Primeval Forest. Research results from the years 1993-1999. Leśne Prace Badawcze, 4: 37-49. (in Polish)

KuBisZ D. 2004. Boros schneideri (PANZER, 1796). [in:] Z. GŁOWACIŃSKI, J. NowACKI (eds.). Polish Red Data Book of Animals. Invertebrates. Instytut Ochrony Przyrody PAN - Kraków i Akademia Rolnicza im. A. Cieszkowskiego, Kraków - Poznań, 139-140. (in Polish)

Kubisz D., PawŁowski J. 1998. Contribution to the knowledge of the beetle fauna (Coleoptera) of the Ojców National Park and its buffer zone (in $145^{\text {th }}$ anniversary of a start of the faunistic inventory at Ojców). Prądnik. Prace i Materiały Muzeum im. W. Szafera, 11-12: 293-323. (in Polish)

Kubisz D., SzwaŁko P. 1991. Coleoptera - species new to the fauna of Podlasie and the Białowieża Primeval Forest. Wiadomości Entomologiczne, 10 (1): 5-14. (in Polish)

KugelanN J.G. 1794. Verzeichniss der in einigen Gegenden Preussens bis jetzt entdeckten KäferArten, nebst kurzen Nachrichten von denselben. Neuestes Magazin für die Liebhaber der Entomologie, 1 (3): 513-582.

KunTZE R. 1936. Critical review of pests from the order of beetles registered in Poland in the years 1919-1933. Rocznik Ochrony Roślin, 3 (2): 1-116. (in Polish)

LENTZ F.L. 1879. Catalog der Preussischen Käfer neu bearbeitet. Beiträge zur Naturkunde Preussens, 4: $1-64$.

LETZNER K. 1871. Verzeichniss der Käfer Schlesiens. Zeitschrift für Entomologie, N.F., 2: 1-328.

LETZNER K. 1888. Fortsetzung des Verzeichnisses der Käfer Schlesiens. Zeitschrift für Entomologie, N.F., 13: 181-236. 
LGOCKI H. 1908. Beetles (Coleoptera) collected in the vicinity of Częstochowa in the Kingdom of Poland in the years 1899-1903. Sprawozdanie Komisji Fizjograficznej, 41: 18-151. (in Polish)

LundBerg S. 1981. The beetle fauna of Gotska Sandön - new findings and interesting species (Coleoptera). Entomologisk Tidskrift, 102 (4): 147-154. (in Swedish)

Melke A., Grzywocz J. 2003. Carpophilus pilosellus MotsChulsky, 1858 (Coleoptera, Nitidulidae) new beetle in Polish entomofauna and some interesting data on other species. Acta entomologica Silesiana, 11 (1-2): 102-105. (in Polish)

MerTLIK J. 2011. Faunistic grid mapping of several saproxylic beetles on territory Czech Republic and Slovakia (Version: 1.1.2015). Permanent electronic publication available from: http://www. elateridae.com/page.php?idcl=173 (in Czech)

MiŁKowski M. 2017. Contribution to the knowledge of beetles (Insecta: Coleoptera) of the Health Resort Park in Nałęczów. Przegląd Przyrodniczy, 28 (1): 91-100. (in Polish)

MiŁKowski M., Wojas T. 2008. Two new localities of Nemosoma caucasicum MÉNÉTR. (Coleoptera: Trogossitidae) in Poland. Wiadomości Entomologiczne, 27 (3): 172. (in Polish)

MoKRZYCKI T. 2001. An attempt to valorize older forest stands of the Białowieża Primeval Forest by the zooindication method on the example of beetles (Coleoptera) of the surface of trunks. [in:] A. SzUJECKI (ed.). An attempt of estimated valorization of woods of the Białowieża Primeval Forest using the zooindication method. Wydawnictwo SGGW, Warszawa, 267-285. (in Polish)

MoKRZYCKI T., BYK A., BorowsKi J. 2008. Rare and relict saproxylic beatles (Coleoptera) of old oaks of the Rogalin Landscape Park. Parki Narodowe i Rezerwaty Przyrody, 27 (4): 43-56. (in Polish)

Nieto A., AleXAnder K.N.A. 2010. European red list of saproxylic beetles. Publications Office of the European Union, Luxembourg.

NowicKI M. 1873. Verzeichniss galizischer Käfer. [in:] Beiträge zur Insektenfauna Galiziens. Kraków, 7-52.

Nowotny H., PolentZ G. 1933. Beiträge zur schlesischen Käferfauna. Entomologischer Anzeiger, 13: $12-15,31-35$.

Olbrycht T., MelKe A., KuBERSKi Ł. 2015. The occurrence of Rhysodes sulcatus (FABRICIUS, 1787) and Boros schneideri (PANZER, 1796) (Coleoptera) in Natura 2000 sites "Bieszczady" (east part) and "Moczary". Roczniki Bieszczadzkie, 23: 189-197. (in Polish)

PANKow W. 2010. Nemozoma caucasicum MÉNÈTRIÈs, 1832 (Coleoptera, Trogositidae) neu in Deutschland. Mitteilungen des Entomologischen Vereins Stuttgart, 45: 87.

PAPIS M., MoKRZYCKi T. 2015. Saproxylic beetles (Coleoptera) of the strictly protected area Bukowa Góra in the Roztoczański National Park. Forest Research Papers, 76 (3): 229-239. (in Polish)

PawŁowsKi J.S. 1967. Beetles (Coleoptera) of Babia Góra. Acta Zoologica Cracoviensia, 12: 419665. (in Polish)

PawŁowsKi J.S. 1968. Beetles new to Fauna of Babia Góra Mt. (Coleoptera). III. Fragmenta Faunistica, 14 (10): 209-229. (in Polish)

PawŁowski J., Kubisz D., Mazur M. 2002. Coleoptera Beetles. [in:] Z. GŁowaciŃSKi (ed.). Red list of threatened Animals in Poland. Wydawnictwo Instytutu Ochrony Przyrody PAN, Kraków, 88-110. (in Polish) 
PAwŁowski J., KuśKA A. 1987. A beetle fauna (Coleoptera) from the "Wolbrom 2" profile. Preliminary results. Acta Palaeobotanica, 27 (1): 117-120.

PawŁowski J., Mazur M., MŁynarski J. K., Stebnicka Z., Szeptycki A., Szymczakowski W. 1994. Beetles (Coleoptera) of Ojców National Park and its environs. Studies and Reports of the Professor Władysław Szafer Museum, Ojców. (in Polish)

Plewa R., Hilszczański J., Jaworski T., Sierpiński A. 2014. New and rare saproxylic beetles (Coleoptera) of eastern Poland. Wiadomości Entomologiczne, 33 (2): 85-96. (in Polish)

PolENTZ G. 1942. Beiträge zur schlesischen Käferfauna. Zeitschrift für Entomologie, 19 (1): 4-11.

ReITTER E. 1870. Uebersicht der Käfer-Fauna von Mähren und Schlesien. Verhandlungen des Naturforschenden Vereins in Brünn, 8 (2): 1-195.

RENDSChMidT F. 1841. Silpha subterranea, neu für Schlesiens Fauna und einige seltene in Schlesien Käfer-Arten. Uebersicht der Arbeiten und Veränderungen der schlesischen Gesellschaft für vaterländische Cultur, 1840: 84 .

RIEHN H. 1912. Käfer als regelmässige Bergwerksbewohner. Entomoligische Mitteilungen, 1 (3): $83-95$.

ROGER J. 1856. Verzeichniss der bisher in Oberschlesien aufgefundenen Käferarten. Zeitschrift für Entomologie, 10: 1-132.

Rossa R. 2004. Calitys scabra (Thunberg, 1784). [in:] Z. GŁOWACIŃSKi, J. NowaCKi (eds.). Polish Red Data Book of Animals. Invertebrates. Instytut Ochrony Przyrody PAN, Akademia Rolnicza im. A. Cieszkowskiego, Kraków - Poznań, 127-128. (in Polish)

ROTTENBERG A. 1864. Eine Excursion nach Albendorf in der Grafschaft Glatz. Berliner Entomologische Zeitschrift, 8: 39-395.

RotTEnBerg A. 1868. Eine Excursion nach der Babia Gora. Berliner Entomologische Zeitschrift, 11: $408-411$.

RUSZKOWSKI J. W. 1933. The results of research on the harmful fauna of Poland based on materials from 1919-1930. Roczniki Ochrony Roślin, 1 (1-3): 1-567. (in Polish)

RUTA R. 2007. Beetles (Insecta: Coleoptera) of the xerothermic Byszewice Hills in the Noteć River Valley. Nowy Pamiętnik Fizjograficzny, 5 (1-2): 49-107. (in Polish)

Ruta R., MelKe A. 2002. Beetles (Insecta: Coleoptera) of the „Kuźnik” reserve near Piła. Rocznik Naukowy Polskiego Towarzystwa Ochrony Przyrody „Salamandra”, 6: 57-101. (in Polish)

Ruta R., Orzechowski R., Aleksandrowicz O., Borowski J., Buchholz L., Komosiński K., Lubecki K., PrZewoźny M. 2016. Beetles (Insecta: Coleoptera) of Gryżyński Landscape Park. Przegląd Przyrodniczy, 27 (2): 28-62. (in Polish)

RutKIEwicZ A. 2001. An attempt to valorize forests of the Białowieża Primeval Forest by the zooindication method on the example of nonphytophagous subcortical beetles (Coleoptera). [in:] A. SzUJECKI (ed.). An attempt of estimated valorization of woods of the Białowieża Primeval Forest using the zooindication method. Wydawnictwo SGGW, Warszawa, 319-332. (in Polish)

RUtKIEwicz A. 2002. Valorization of forests of the Białowieża Primeval Forest basing on subcortical beetles. [in:] VII Symposium on the protection of forest ecosystems. Forest economic tasks and nature protection functions. Rogów, March 25-27, 2002. Wydawnictwo SGGW, Warszawa, 231245. (in Polish) 
SCHMiDT G. 1935. Biologische und faunistische Beiträge zur Kenntnis der pommerschen Fauna unter besonderer Berücksichtigung der Käfer. Dohrniana, 14: 101-121.

SChмiDT G. 1938. Einige interessante Käferfunde in der Neumark. Entomologische Blätter, 34 (1): $44-45$.

Schumann E. 1904. Der Eichwald bei Posen. Eine koleopterologische Betrachtung. Zeitschrift der Naturwissenschaftlichen Abteilung. Deutsche Gesellschaft für Kunst und Wissenschaft in Posen, 11 (1): 15-21.

SENICZAK S. 1968. Invasion of the zone of spruce crowns by bark-beetles and the accompanying entomofauna in dependence on the forest stand layer in the experimental forest inspectorate Laski. Prace Komisji Nauk Rolniczych i Leśnych Poznańskiego Towarzystwa Przyjaciół Nauk, 25: 325-354. (in Polish)

SIENKIEWICZ P. 2004. Rhysodes sulcatus (FABRICIUS, 1787), Wrinkled Bark Beetle. [in:] Z GŁOWACIŃSKI, J. NowACKI (eds.). Polish Red Data Book of Animals. Invertebrates. Instytut Ochrony Przyrody PAN, Akademia Rolnicza im. A. Cieszkowskiego, Kraków - Poznań, 91-92. (in Polish)

SkURATOWiCZ W., UrbaŃSKi J. 1953. The forest reservation on Bukowa Góra near Zwierzyniec (Lublin Voivodeship) and its fauna. Ochrona Przyrody, 21: 193-216. (in Polish)

Starzy J.R., Grodzki W., Kosibowicz M., Michalcewicz J., Rossa R. 2008. Old and dead trees as the site of occurrence and development of xylobiotic and dendrophilus beetles. Roczniki Bieszczadzkie, 16: 325-348. (in Polish)

StefeK K. 1939. Supplément nécessaire pour les études des coléoptères en Silésie et de ses environs. Prace Oddziału Przyrodniczego Muzeum Śląskiego, 1: 125-174. (in Polish)

Stobiecki S. A. 1883. To the fauna of Babia Góra mountain. Report on entomological trips to Babia Góra in 1879 and 1880. Sprawozdanie Komisji Fizyograficznej, 17: 1-84. (in Polish)

SZAFRANIEC S. 1997. Beetles (Coleoptera) new for the Babia Góra massif. Wiadomości Entomologiczne, 15 (4): 207-215. (in Polish)

SzAFRANIEC S., SzOŁTYS H. 1997. Materials for recognition of the cambium- and xylobiontic beetles (Coleoptera) occurrence in the Katowice Province nature reserves. Natura Silesiae Superioris, 1: 43-55. (in Polish)

SZAFranieC S., SzOŁtys H., MelKe A. 1999. Materials for recognition of the saproxylic beetles in the selected projected nature reserve in the former Katowice Province. Natura Silesiae Superioris, 3: 77-86. (in Polish)

Szulczewski J.W. 1922. Beetles of Great Poland. Prace Komisji Matematyczno-Przyrodniczej Poznańskiego Towarzystwa Przyjaciół Nauk, 1 (3/4): 183-243. (in Polish)

Szwatko P., KubISZ D. 1994. New records of Tenebroides fuscus (GoEzE) (Coleoptera: Trogossitidae) in Poland. Acta entomologica Silesiana, 2 (2): 46. (in Polish)

TATUR-DYTKOWSki J. 2018 [2017]. Nemozoma caucasicum MÉNÉTRIÉs, 1832 (Coleoptera: Trogossitidae) in Warsaw and notes on its biology. Wiadomości Entomologiczne, 36 (4): 244 245. (in Polish)

Tenenbaum S. 1913. Beetles (Coleoptera) collected in the Zamoyski Family Fee Tail in the Lublin province. Pamiętnik Fizyograficzny, 21: 1-72. (in Polish) 
TYKARSKI P. 2006. Beetles associated with scolytids (Coleoptera, Scolytidae) and the elevational gradient: Diversity and dynamics of the community in the Tatra National Park, Poland. Forest Ecology and Management, 225 (1-3): 146-159.

VIERTL A. 1872. Contribution to the fauna of Galicja. b) Beetles (Coleoptera) from the vicinity of Tarnów. Sprawozdanie Komisji Fizjograficznej, 6: 65-69. (in Polish)

WACHTL F. 1870. Checklist of beetles of the basins of the rivers Soła and Koszarawa. Sprawozdanie Komisji Fizjograficznej, 4: 246-262. (in Polish)

WANKA Th. v. 1915. Beitrag zur Coleopterenfauna von Österr.-Schlesien. Wiener Entomologische Zeitung, 34: 199-214.

ZeBE G. 1852. Synopsis der bisher in Deutschland aufgefundenen Coleoptera. Stettiner entomologische Zeitung, 13: 129-136, 161-176, 209-216, 241-256, 289-296, 329-336, 369376, 409-416, 455-462.

Received: 26 March 2018

Accepted: 27 June 2019 